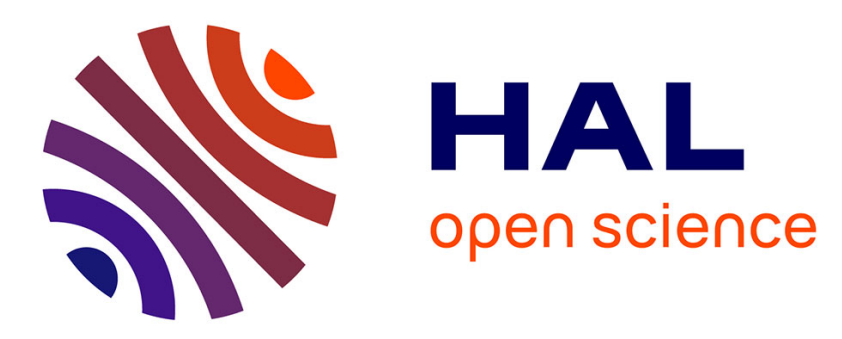

\title{
Uranium mineralization in the Alum Shale Formation (Sweden): Evolution of a U-rich marine black shale from sedimentation to metamorphism
}

Andreï Lecomte, Michel Cathelineau, Raymond Michels, Chantal Peiffert, Marc Brouand

\section{To cite this version:}

Andreï Lecomte, Michel Cathelineau, Raymond Michels, Chantal Peiffert, Marc Brouand. Uranium mineralization in the Alum Shale Formation (Sweden): Evolution of a U-rich marine black shale from sedimentation to metamorphism. Ore Geology Reviews, 2017, 88, pp.71-98. 10.1016/j.oregeorev.2017.04.021 . hal-02376740v2

\section{HAL Id: hal-02376740 \\ https://hal.science/hal-02376740v2}

Submitted on 29 Nov 2019

HAL is a multi-disciplinary open access archive for the deposit and dissemination of scientific research documents, whether they are published or not. The documents may come from teaching and research institutions in France or abroad, or from public or private research centers.
L'archive ouverte pluridisciplinaire HAL, est destinée au dépôt et à la diffusion de documents scientifiques de niveau recherche, publiés ou non, émanant des établissements d'enseignement et de recherche français ou étrangers, des laboratoires publics ou privés. 


\title{
Uranium mineralization in the Alum Shale Formation
}

(Sweden): evolution of a U-rich marine black shale from

\author{
sedimentation to metamorphism
}

Andreï Lecomte ${ }^{1, *}$, Michel Cathelineau ${ }^{1}$, Raymond Michels ${ }^{1}$, Chantal Peiffert ${ }^{1}$, Marc Brouand $^{2}$

${ }^{1}$ GeoRessources, Université de Lorraine, CNRS, CREGU, Boulevard des Aiguillettes B.P. 70239 F-54506 Vandoeuvre lès Nancy, France

${ }^{2}$ AREVA, 1 place Jean Millier. F-92084 Paris La Défense Cedex, France

${ }^{*}$ Corresponding author: GeoRessources, Boulevard des Aiguillettes B.P. 70239 F-54506 Vandoeuvre-lès-Nancy, France

E-mail address: Andrei.Lecomte@univ-lorraine.fr

Tel: (33) (0)3 83684729

Fax: (33) (0)3 83684701 


\section{Graphical abstract}

Sedimentation $\longrightarrow$ Early diagenesis $\longrightarrow$ Late diagenesis $\longrightarrow$ Metamorphism

Hydrocarbon generation

and migration

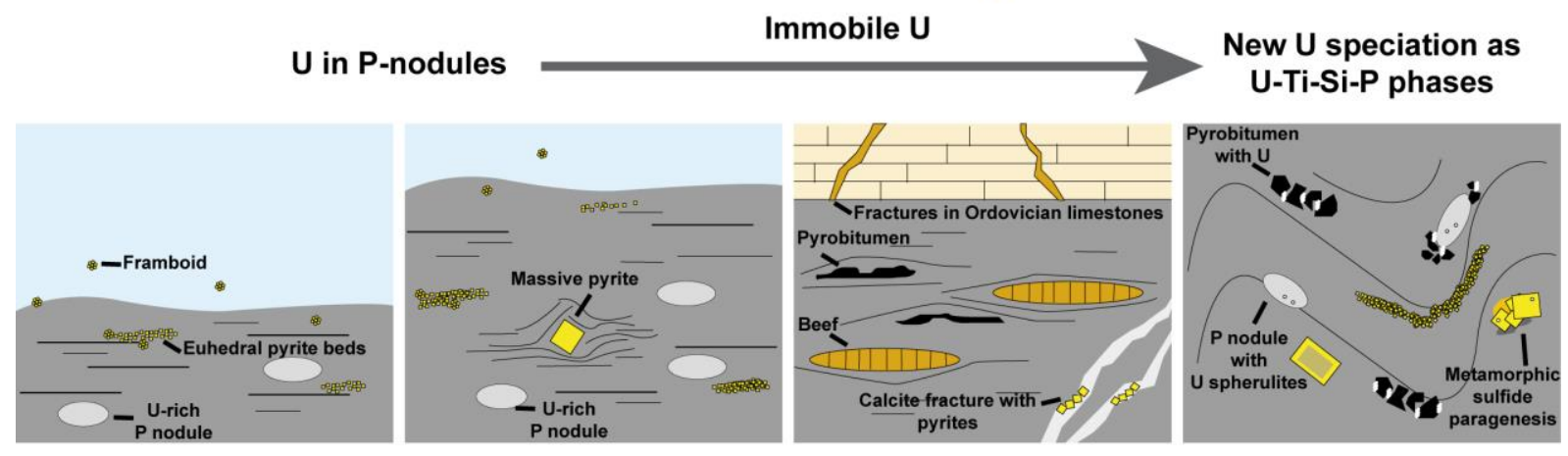




\section{Abstract}

The Alum Shale Formation is a metal-rich black shale, deposited on the Baltoscandian platform between Middle Cambrian and Early Ordovician. These black shales may be of particular economic interest for their relatively high uranium content (100-300 ppm) and their wide distribution from Norway to Estonia. Scandinavian Alum Shale may thus constitute a great potential resource of uranium, as a low grade ore. The Alum Shale Formation is particularly interesting to study the mineralogical expression and content of uranium in series submitted to progressive burial and metamorphism. For this purpose, the behavior of $\mathrm{U}, \mathrm{P}, \mathrm{Ti}$ and organic matter was studied on a series of representative samples from most Alum Shale prospection zones. In southern Sweden, where Alum Shale underwent fairly shallow burial, uranium concentrations have no mineralogical expression except a rather high U content of biogenic phosphates. Calcite concretions (beefs) and fractures recorded the migration of hot overpressured hydrocarbons and brines from thermally mature areas to immature Alum Shale. However, thermal maturation and fluid migration did not allow remobilization of uranium and metals. At the opposite, in northern Sweden, where the series were folded, duplicated and submitted to low grade Greenschist metamorphism during Caledonian orogeny, phospho-silicates U-Si-Ca-P $( \pm \mathrm{Ti} \pm \mathrm{Zr} \pm \mathrm{Y})$ and minor amounts of uraninite are identified and indicate that $\mathrm{U}, \mathrm{P}$, and $\mathrm{Ti}$ were mobile and precipitated as new phases. The effect of metamorphism is therefore important to consider as the leachability of $U$, especially during (bio)hydrometallurgical processes, which will be by far different between the two considered areas. 
Keywords: uranium; Alum Shale; organic matter; metamorphism; fluid inclusions; hydrocarbons 


\section{Introduction}

Lower Palaeozoic black shales extend over most of northern Europe, from Norway to Estonia across the Baltic Sea. These sediments were deposited on the Baltoscandian platform during an interval of great tectonic stability (Andersson et al., 1985). In particular, the Alum Shale Formation is an organic-rich marine sequence deposited over present Scandinavia between Middle Cambrian and Early Ordovician. The name Alum refers to the alum salt $\mathrm{KAl}\left(\mathrm{SO}_{4}\right)_{2} \cdot 12 \mathrm{H}_{2} \mathrm{O}$ that formed under supergene conditions and was extracted from this black shale over 300 years ago. As many other black shales deposited in marine environments, Alum Shale contains high metal concentration compared to ordinary shales, especially $\mathrm{Ni}$, Mo, Co, Cu, Zn, U, V, As, Se, Ag, Au and PGE (Vine and Tourtelot, 1970; Holland, 1979; Wignall, 1994). Nevertheless, Scandinavian Alum Shale is of particular interest because of its somewhat higher uranium content (100-300 ppm) and its wide extension. Therefore, they may constitute a potential uranium resource for the future.

The Alum Shale Formation is particularly interesting for the study of the mineralogical expression and content of uranium in series submitted to progressive burial and metamorphism. In order to understand the behavior of $\mathrm{U}, \mathrm{P}, \mathrm{Ti}$ and organic matter at increasing P-T conditions, a series of representative samples from most Alum Shale prospection zones were studied: i) samples from southern Sweden, where Alum Shale underwent rather shallow burial, and ii) samples from northern Sweden, where Alum Shale was folded, duplicated and submitted to low grade Greenschist metamorphism during Caledonian orogeny. The main objective was to identify the mineralogical expression of metals and uranium in these low grade ores, 
and especially changes expected to occur during burial and metamorphism. Indeed, the nature of the $U$ bearers is poorly known, and was almost not studied, most available data dealing with bulk $\mathrm{U}$ grades for evaluation of the mining potential and radioprotection purposes (Armands, 1972; Parnell, 1984; Andersson et al., 1985; Buchardt et al., 1997). Knowledge about the form at which U occurs in the ore is valuable information regarding ore treatment processes and recoverable reserve estimation.

\section{Geological setting}

In Sweden, the Alum Shale Formation can be subdivided into three geographical and structural provinces (Fig. 1): (a) autochthonous platform cover units (southern Sweden) lying on the Proterozoic basement, unaffected by Caledonian orogeny; (b) parallochthonous Alum Shale duplicated along the Caledonian Front with a metamorphic and hydrothermal imprint during the Caledonian orogeny (420-400 Ma); (c) allochthonous units in Sweden and Norway showing Greenschist facies metamorphic grade (Sundblad and Gee, 1984). The Alum Shale Formation is a marine sequence deposited between Middle Cambrian and Early Ordovician (Tremadoc) on Lower Cambrian sediments, the latter resting on a crystalline Palaeoproterozoic basement (Nielsen and Schovsbo, 2007). The sedimentation took place in a shallow-water epicontinental basin bordered by the Tornquist Sea to the South and the Iapetus Ocean to the North and West (Scotese and McKerrow, 1990). In the Early Cambrian, rising sea-level led to extensive flooding over the Baltoscandian sector of Baltica. A succession of transgressive and regressive 
events occurred early to Middle Cambrian and ended with major Hawke Bay regression, terminating deposition of Lower Cambrian sediments (Nielsen and Schovsbo, 2011). During Middle Cambrian, marine transgression shifted the paleoshoreline to the north-east (Andersson et al., 1985; Buchardt et al., 1997; Schovsbo, 2002). From then, Baltoscandian epicontinental sea was characterized by extremely low depositional rates and dysoxic to anoxic conditions, especially in the deeper parts of the basin (Nielsen and Schovsbo, 2015). These particular conditions prevailed until Early Ordovician and favored Alum Shale deposition. During Caledonian orogeny, Alum Shale underwent Greenschist facies metamorphism. Besides, in the Caledonian foreland basin and in southern Sweden and Denmark, deep burial (up to $4 \mathrm{~km}$ ) initiated thermal maturation of organic matter and hydrocarbon generation (Buchardt et al., 1997, Schovsbo et al., 2011).

The Alum Shale Formation is generally 15-35 meters thick but extremely variable, from 2 meters in Öland to 95 meters in Skåne. In the Caledonides, the formation is duplicated by thrust sheets and the thickness reaches up to 180 meters (Andersson et al., 1985). Scandinavian Alum Shale is dominated by organic-rich (up to $20 \%$ TOC) marine black shales, with variable proportions of grey shales and silt beds, limestones and carbonate concretions. The latter generally trapped large amounts of hydrocarbons (Andersson, 1985; Thickpenny, 1984). In the Upper Cambrian, small lenses of organic matter (kolm) occur and are often highly uraniferous (up to $5000 \mathrm{ppm}$ ).

\section{Sampling and analytical procedure}


Sampling procedure aimed at selecting representative black shale samples of various thermal maturity, from immature or slightly mature Alum Shale to metamorphic rocks. Several locations were selected, with the least mature black shales (Västergötland, Östergötland, Närke and Öland), overmature Alum Shale in Skåne and metamorphic Alum Shale (Lövstrand, Myrviken and Tåsjö). Sampling locations are indicated on figure 1. Samples were taken on several drill cores stored in SGU's coreyards (Geological Survey of Sweden) and are listed in table 1. Most of these cores correspond to historical drilling projects. Studies were conducted on thin sections and polished sections, the latter included with Araldite in an aluminum ring of $25 \mathrm{~mm}$ diameter.

Petrographical studies were done using optical microscopes in reflected light, a SEM Hitachi S-4800 coupled to a ThermoNORAN Si(Li) detector, and a FEG SEM JEOL 7600F (hot cathode) with an Oxford Instruments SDD-type EDS spectrometer. Analyses were performed at $10 \mathrm{kV}$. Electron Probe Micro-Analysis (EPMA) analyses were performed using a CAMECA SX100, with an acceleration voltage of $20 \mathrm{kV}$ and beam current of $20 \mathrm{nA}$.

X-Ray diffractograms were acquired using a D8 Bruker diffractometer with a non-monochromatic CoKa radiation ( $35 \mathrm{kV}, 45 \mathrm{~mA})$. Air-dried (AD), ethylene glycol (EG)-saturated and $550^{\circ} \mathrm{C}$-heated XRD preparations (fractions $<2 \mu \mathrm{m}$ ) are analyzed to determine diffracted intensities of clays over $3-40^{\circ} 2 \theta$ range with a $0.02^{\circ} 2 \theta$ step and 3 seconds per step.

Multi-elements concentrations in phosphate nodules, carbonaceous residues and fluid inclusions were measured using a LA-ICP-MS system composed of a 
GeoLas excimer laser (ArF, 193 nm, Microlas, Göttingen, Germany) associated with an Agilent 7500c quadrupole ICP-MS. Quantification of the results was achieved using the standard NIST SRM 610 (Pearce et al., 1997) and subroutine data processing (Leisen, 2011). Sample density was calculated for several metamorphic and immature Alum Shale, measuring their volume by water immersion after paraffin coating.

Raman spectra of carbonaceous material from the Alum Shale were acquired using a LabRAM HR microspectrometer (Horiba Jobin Yvon) equipped with a $600 \mathrm{gr} / \mathrm{mm}$ grating, using the $514.53 \mathrm{~nm}$ radiation of an $\mathrm{Ar}^{+}$laser with a final power of about $1 \mathrm{~mW}$ (Stabilite 2017, Newport Spectra Physics). The laser was focused in the sample using a 100X objective. Acquisition time was set in such a way that the intensity reached at least $1 / 3$ of the saturation level of the CCD (i.e. 20000 counts per second). Each measurement is the sum of 6 spectrum acquisition of 30 to 40 seconds each.

Sulfur isotope compositions were measured with a Cameca IMS1280 HR2 (CRPG, Nancy, France) using simultaneous measurements of $32 \mathrm{~S}$, 33S, and $34 \mathrm{~S}$ in multicollection mode, with a $\mathrm{Cs}^{+}$primary beam of 1 AA intensity. Data were corrected for instrumental mass fractionation using several sulfide standards: Maine (pyrite, $\delta^{34} \mathrm{~S}=-19.3 \%$ ) , Spain (pyrite, $\delta^{34} \mathrm{~S}=-2.95 \%$ ), $\mathrm{NiS}\left(\delta^{34} \mathrm{~S}=19.14 \%\right.$ ). Analyses consisted of 3 minutes of presputtering followed by data acquisition in 40 cycles of 3 seconds. Sulfur isotope measurements are reported as part per thousand deviations with respect to Canyon Diablo Troilite using $\delta$ notation.

Microthermometric data were acquired on a Linkam MDS 600 stage coupled with an Olympus BX-51 microscope equipped with a UV-light source (Mercury 
lamp, $\lambda=365 \mathrm{~nm}$ ) allowing the recognition of fluorescent petroleum-bearing fluid inclusions. Phase transition temperatures can be measured between $-196^{\circ} \mathrm{C}$ and $600^{\circ} \mathrm{C}$, with an accuracy of $\pm 0.1^{\circ} \mathrm{C}$. In this study we measured homogenization temperature of hydrocarbon-bearing and aqueous inclusions, which correspond to the transition between a biphasic liquid-vapor inclusion and a monophasic liquid or gas inclusion.

Raman analyses of aqueous inclusions were performed using a LabRAM HR microspectrometer (Horiba Jobin Yvon), using the $457 \mathrm{~nm}$ radiation of an $\mathrm{Ar}^{+}$laser with a final power of about $80 \mathrm{~mW}$. Each measurement is the sum of 4 spectrum acquisition of 30 to 60 seconds each. Beam parameters and accumulation time were adjusted to obtain the best signal/background ratio. Chlorinities of aqueous phases were calculated using the method of Dubessy et al. (2002).

Infrared spectra of hydrocarbons in inclusions are recorded in transmission mode using a Bruker Vertex 70 Fourier transform infrared spectrometer coupled to a Hyperion 3000 microscope. The microscope is equipped with a MCT (mercury cadmium telluride) cooled at $77 \mathrm{~K}$. The size of the beam can be reduced down to a diameter of $20 \mu \mathrm{m}$ with X15 objective magnification. The IR spectra are obtained in the mid-infrared region with a $2 \mathrm{~cm}^{-1}$ spectral resolution. Each sample is scanned about 90 seconds and the influence of atmospheric water and carbon dioxide was always subtracted.

Confocal laser scanning microscopy (CLSM) measurements were acquired on a Biorad rainbow system coupled to a Nikon inverted microscope following procedure described in Pironon et al. (1998). 3D reconstruction was used to calculate the volume 
of gaseous filling at room temperature. Isochores and isopleths of hydrocarbonbearing inclusions were determined with FIT-Oil software (Fluid Inclusion Thermodynamic-Oil, evolution of PIT software; Thiéry et al., 2000) using homogenization temperature and previously calculated $\alpha / \beta$ parameters. $\alpha / \beta$ parameters represent the composition of heavy alkanes $(\geq \mathrm{C} 10)$ and light alkanes, respectively (Montel, 1993; Thiéry et al., 2000). Isochores of aqueous inclusions in the $\mathrm{CH}_{4}-\mathrm{H}_{2} \mathrm{O}-\mathrm{NaCl}$ system, with various $\mathrm{NaCl}$ concentration and $\mathrm{CH}_{4}$ concentration below 1 molal, were calculated using the method of Zhang and Frantz (1987).

\section{Results}

\subsection{Mineralogy of the Alum Shale Formation}

The Alum Shale Formation is an organic-rich marine black shale showing variable facies, from dark gray calcareous mudstone to black laminated mudstone depending on the organic matter content (Fig. 2). Sulfides, especially pyrites, are disseminated throughout the shale. Metamorphic Alum Shale is often folded and present calcite precipitation as pressure shadows around massive pyrite or inside fractures with pyrobitumen. The detrital fraction is composed of quartz, feldspars (orthose and albite) and clays (Fig. 3). Clays composition is slightly variable but always remains dominated by illite and illite-smectite mixed-layer minerals. The latter are characterized by a left shoulder on illite main peak and doublets on secondary peaks. Smectite is emphasized by peak shift after glycolation and peak disappearance after heating at $550^{\circ} \mathrm{C}$. Minor kaolinite and chlorite are also observed. With deep burial and metamorphism, illite peak gets thinner and shows the illitemuscovite transition. 


\subsection{Geochemistry of the Alum Shale Formation}

As many other black shales deposited in marine environments, Alum Shale contains metal concentration higher than ordinary marine shales. In figure 4 , wholerock concentrations of several elements (As, $\mathrm{Co}, \mathrm{Cu}, \mathrm{Cr}, \mathrm{Mo}, \mathrm{Ni}, \mathrm{Pb}, \mathrm{Th}, \mathrm{U}, \mathrm{V}, \mathrm{Zn}$ ) in the Alum Shale Formation and reference metalliferous black shales are plotted and compared to the "Marine Shales" (Turekian and Wedepohl, 1961). Metalliferous black shales include Chinese Cambrian black shales from Tarim basin (Yu et al., 2009), Ronneburg Silurian black shales (Lippmaa et al., 2011) and American Devonian black shales (Ohio shale, Lewis et al., 2010). Complete dataset is in table 2 for eight metamorphic samples (Myrviken, Lövstrand and Tåsjö) and thirteen non metamorphic samples (Närke, Östergötland, Öland, Skåne and Västergötland). The Alum Shale Formation is remarkable because of a particularly higher uranium content compared to other metalliferous black shales. In Upper Cambrian Alum Shale, U content is generally higher than 100 ppm (mean $118 \pm 48$ ppm) and may reach several hundreds ppm. On the contrary in most metalliferous black shale worldwide, U content does not exceed a few tens of ppm.

Besides, in Scandinavian Alum Shale, organic carbon content and total sulfur content (TS) are generally high but values are scattered. Total Organic Carbon (TOC) ranges between 5 and $20 \mathrm{wt.} \%$ (mean 12 $14 \mathrm{wt.} \%$ ) and total sulfur between 4.6 and 6.3 wt.\% (mean 5.5 \pm 0.6 wt.\%). When plotted in a TS vs TOC diagram (Fig. 5a), Alum Shale analyses display a positive correlation across "euxinic sediments" and "normal oxygenated sediments" fields. This correlation line crosscut TS-axis at around 4.9 wt.\%. Moreover, whole-rock $\mathrm{V} / \mathrm{Cr}$ and $\mathrm{V} /(\mathrm{V}+\mathrm{Ni})$ ratios are high, between 4.26 and 
18.67 (mean 9.19 \pm 4.65 ) and between 0.68 and 0.85 (mean $0.77 \pm 0.04$ ), respectively (Fig. $5 b)$.

Finally, when plotted against both organic carbon (Fig. 6a) and phosphorus (Fig. 6b) concentrations, uranium content displays a positive correlation. In particular, density-corrected uranium concentration increases along with total organic carbon following two different trends for metamorphic and immature samples. Indeed, in metamorphic Alum Shale, U concentration increases with a steeper slope than in immature samples. Thus, for equivalent percentages of organic carbon, metamorphic samples are twice as rich as immature samples.

\subsection{Carbon, sulfur and uranium in immature Alum Shale}

\subsubsection{Organic matter accumulation}

In immature Alum Shale, organic matter is composed of fluorescent liptinite and non-fluorescent pseudo-vitrinite (Fig. 7a and 7b). In most immature samples, liptinite displays yellow-green fluorescence, whereas Västergötland's lipnite is scarcer and shows orange-brown fluorescence. Rock-Eval results are listed in table 3. Rock-Eval S1 values are between 0.45 and $1.71 \mathrm{mg} \mathrm{HC} / \mathrm{g}$ Rock and S2 values between 13.00 and 99.94 mg HC/g Rock. Hydrogen Index (HI) values range between 132 and $544 \mathrm{mg} \mathrm{HC} / \mathrm{g}$ TOC. Tmax values range between 406 and $426^{\circ} \mathrm{C}$ confirming immature organic matter (Tissot and Welte, 1984). When plotted in a S2 versus TOC diagram (Fig. 8), immature Alum Shale lines up on the Type II organic matter trend (Langford and Blanc-Valleron, 1990). Västergötland's Alum Shale appears to be anomalous with lower IH values, which may be related to previously described maceral composition. In IH-Tmax (Fig. 9) and S1-S2 (Fig. 10) diagrams, organic 
matter falls in the immature Type II area, with an excellent petroleum potential.

\subsubsection{Sulfide paragenesis during sedimentation and diagenesis}

The Alum Shale Formation contains sulfide mineralization, in particular pyrites with various shapes and distributions (Fig. 11): (a) disseminated spherolites or framboids in shale layers and rarely in bitumen; (b) small anhedral crystals scattered in black shale; (c) beds or clusters of small euhedral crystals, mostly underlining sedimentary bedding; (d) massive anhedral to euhedral pyrites; (e) pyrite cements and overgrowths in fractures.

In immature Alum Shale, five pyrite generations (named Py1 to Py5 in tables and figures) have been identified over petrographic features. The first generation corresponds to disseminated framboids and small euhedral crystals following shale stratification. The second generation occurs as beds or nodules of massive pyrite and may be locally reworked and cemented framboids clusters. This recrystallization stage seems to be synchronous with partial pyrite cementation of detrital grains. The third generation is represented by large pyrite crystals which are either scattered in the shale or grow on recrystallized -mainly framboids- beds perpendicularly to the shale bedding. Massive pyrites display a homogeneous texture, sometimes with growth zones, and may deform shale lamination. The fourth generation corresponds to fracture infillings as pyrite cement or large-scale euhedral crystals. Cementation is not homogeneous and has high porosity. The fifth generation occurs as homogeneous pyrite veins and small pyrite overgrowths.

Trace elements content in sulfides is often helpful to distinguish different precipitation conditions. In the case of immature Alum Shale, no particular 
enrichment was measured in pyrites, except for framboids, where $\mathrm{Cu}$ and As concentrations are higher than co-genetic euhedral pyrites (Fig. 12a and b).

Every pyrite generation was analyzed by SIMS (Secondary Ion Mass Spectrometry) to determine sulfides isotopic composition. Sulfur isotopic data are listed in table 4 and represented as a histogram (Fig. 13). First generation (clusters of framboids and euhedral crystals) shows high $\delta^{34} S$ values between 30 and 40\%. One single framboid was analyzed and has a slightly negative $\delta^{34} S(-4 \%)$. Second pyrite generation values range between 22 and 26\%o. Third generation correspond to massive pyrites. Analyses yield $\delta^{34} S$ results between 18 and 25\%o. Inside most crystals, neither chemical zoning nor isotopic composition gradient was observed. However, isotopic zoning was measured into a large pyrite with $\delta^{34} S$ increasing from core to rim (16\% to $23 \%$ o). Besides, a small pyrite inclusion in the center shows high sulfur isotopic composition $\left(\delta^{34 S}=33 \%\right.$ ) similar to that of first generation. Fourth generation cementing massive pyrites shows homogeneous $\delta^{34} S$ values $(30-31 \%$ ). Rare subhedral pyrites on the edges of these cemented areas have the same isotopic signature. In homogeneous fracture infillings and late pyrite overgrowths (fifth generation), $\delta^{34} \mathrm{~S}$ ranges between 19 and $23 \%$.

\subsubsection{Uranium concentration in immature shales}

No detectable uranium mineral was observed in immature Alum Shale. However, in the Alum Shale Formation, calcium phosphate nodules are disseminated and generally parallel to the stratification. These nodules are several hundreds of micrometers long and are composed of apatite-(CaF[OH]) (Fig. 14). REE analyses (Table 5) were carried out using LA-ICP-MS. REE spectra normalized to 
North American Shale Composite (NASC REE concentrations after Gromet et al., 1984) are plotted in figure 15a. Apatite- $(\mathrm{CaF}[\mathrm{OH}])$ nodules display bell-shaped REE patterns, centered on Eu. Such patterns are similar to those measured on pre-jurassic biogenic marine phosphates. Uranium concentration in these phosphate nodules were measured with LA-ICP-MS. The results (Table 5) show between 131 and 185 ppm uranium grades.

\subsection{Impact of burial and thermal maturation on organic matter and uranium}

\subsubsection{Thermal maturation of the Alum Shale Formation and oil generation}

Burial and thermal maturation of Alum Shale lead to oil and gas generation. Hydrocarbons are present as pyrobitumen or impregnation of phosphate nodules in the black shale, but also as fluid inclusions in calcite crystals (Fig. 16a and b), which occur as: (a) carbonate concretions composed of large fibrous calcite crystals, up to 10 centimeters long. These concretions, parallel to shale bedding, may be up to 1.5 meters long and 50 centimeters thick. The core is made of microcrystalline calcite and bioclasts, whereas rims are recrystallized in pure calcite with frequent cone-in-cone structures. (b) brecciated levels composed of centimetric non-oriented angular particles of pure calcite in a matrix of microcrystalline calcite and detrital grains; (c) fractures with calcite infillings in Ordovician limestones.

Fluid inclusions (Fig. 16c to d), in particular petroleum inclusions, are abundant in breccias and fractures, but scarce in fibrous crystals. They are mostly biphasic $\mathrm{L}_{w}-\mathrm{V}$ (liquid water and vapor bubble) or $\mathrm{L}_{\mathrm{oil}}-\mathrm{V}$ (liquid oil and vapor bubble), although some monophasic $\mathrm{L}_{\mathrm{oil}}$ or triphasic $\mathrm{L}_{\mathrm{w}}-\mathrm{L}_{\mathrm{oil}}-\mathrm{V}$ inclusions have been observed. In 3-phase inclusions, oil always occurs as droplets in aqueous phase and vapor 
phase is contained in oil (Fig. 16f). Shapes vary from rounded or ellipsoidal shapes for aqueous or small oil inclusions to irregular shapes for large petroleum inclusions. Most inclusions are small $(<10 \mu \mathrm{m})$ although a few can reach several tens of microns. Distribution of fluid inclusion is not homogeneous in calcite crystals. They are generally clustered (several inclusions to tens of inclusions of various size) or distributed along calcite cleavage planes. These fluid inclusion planes are tens to hundreds of microns long and are always constrained within a single crystal. Oil is generally yellow to brown, rarely colorless. Under UV-epifluorescence, petroleum inclusions display various colors: yellow to orange-brown for most of them, white, blue, or green-blue. Isolated and clustered inclusions in concretions or fractures are considered as primary inclusions trapped during calcite growth. Short intragranular fluid inclusion planes are taken as primary when parallel to cleavage or rarely pseudo-secondary when randomly oriented. A few planes are obviously posterior to calcite crystallization and are labeled as secondary. These intergranular trails contain small oil inclusions with blue-colored UV-epifluorescence and crosscut crystal fabrics.

Homogenization temperatures $\left(T_{h}\right)$ were measured on 213 fluid inclusions (185 oil inclusions and 28 aqueous inclusions) from 6 concretion samples, and 207 inclusions (172 oil inclusions and 35 aqueous inclusions) in 3 limestone fractures. Distinction between inclusions was made according to the parameters previously described: host rock (concretion/breccia or fractures), timing of formation (primary, pseudo-secondary or secondary), liquid phase (oil or water) and fluorescence color (yellow-orange-brown or white-blue). Microthermometry results are presented in 
histograms (Fig. 17).

In calcite crystals from concretions and breccias (Fig. 17a), homogenization temperatures show a wide range of values between 60 and $200^{\circ} \mathrm{C}$. $\mathrm{T}_{\mathrm{h}}$ distribution of petroleum inclusions is bimodal with a primary mode between 70 and $100^{\circ} \mathrm{C}$ and a secondary mode between 120 and $150^{\circ} \mathrm{C}$. Inclusions with yellow-orange-brown fluorescence have principal and secondary modes centered around $80^{\circ} \mathrm{C}$ and $130^{\circ} \mathrm{C}$, respectively. Inclusions with white-blue fluorescence have principal and secondary mode centered around $90^{\circ} \mathrm{C}$ and $140^{\circ} \mathrm{C}$, respectively. $\mathrm{T}_{\mathrm{h}}$ of aqueous inclusions range between 90 and $170^{\circ} \mathrm{C}$, with a unimodal distribution centered around $140^{\circ} \mathrm{C}$. The distribution of oil inclusions is essentially driven by primary and pseudo-secondary inclusions. $\mathrm{T}_{\mathrm{h}}$ of blue-fluorescing secondary inclusions range between 83 and $105^{\circ} \mathrm{C}$. In fractures (Fig. 17b), inclusions have a wide range of $\mathrm{T}_{\mathrm{h}}$ between 5 and $190^{\circ} \mathrm{C}$. Inclusions with yellow-orange-brown fluorescence have principal and secondary modes centered around $100^{\circ} \mathrm{C}$ and $150^{\circ} \mathrm{C}$, respectively. Inclusions with white-blue fluorescence have unique mode centered on $100^{\circ} \mathrm{C} . \mathrm{T}_{\mathrm{h}}$ of aqueous inclusions range between 90 and $180^{\circ} \mathrm{C}$, with a unimodal distribution centered around $150^{\circ} \mathrm{C}$.

Determination of chlorinity in aqueous phase and gas content in fluid inclusions were performed with Raman spectroscopy. Only aqueous inclusions were analyzed due to high fluorescence of hydrocarbons disrupting Raman signal. Water chlorinity was calculated at room temperature from band area ratio of water phase. 9 inclusions in concretions have salinities between 9.5 and 20.9 wt.\% eq. $\mathrm{NaCl}$ (mean $15 \pm 3.2$ wt.\% eq. $\mathrm{NaCl}$ ). 3 inclusions in fractures have salinities between 12 and 19.4 wt. \% eq. $\mathrm{NaCl}$ (mean $16 \pm 3.7$ wt.\% eq. $\mathrm{NaCl}$ ). Besides, composition of gaseous 
phase was analyzed in aqueous inclusions. Methane is always detected and is sometimes associated with carbon dioxide. However, dissolved methane concentration at homogenization temperature was not detected, which indicates rather low concentration in $\mathrm{CH}_{4}$.

Infrared spectroscopy was used to investigate composition of petroleum inclusions (Table 6 for inclusions observed with confocal laser scanning microscopy). $\mathrm{CH}_{4}$ content in concretions and fractures is variable and range between 26.2 and $47.3 \mathrm{~mol} \%$ (mean $38.3 \pm 7.8 \mathrm{~mol} \%$ ) and between 16.9 and $48.7 \mathrm{~mol} \%$ (mean $30.9 \pm 9.8 \mathrm{~mol} \%)$, respectively. $\mathrm{CO}_{2}$ was not detected in most concretion inclusions but was present at low concentration (0.3 to $2.9 \mathrm{~mol} \%)$ in fracture inclusions. In the same way, alkane content varies greatly within samples: 52.5 to $73.8 \mathrm{~mol} \%$ (mean $61.7 \pm 6.9 \mathrm{~mol} \%$ ) in breccias and concretions; 50.7 to $80.9 \mathrm{~mol} \%$ (mean $68 \pm 9.5 \mathrm{~mol} \%$ ) in limestone fractures. All these parameters are not correlated with host mineral, homogenization temperature or fluorescence color. Only $\mathrm{CO}_{2}$ concentration seems to be slightly higher in fractures than in concretions. On the contrary, $\mathrm{CH}_{2} / \mathrm{CH}_{3}$ ratio is clearly distinct between host minerals. In concretions and breccias, ratios vary between 1 and 3.6 (mean 2.4 \pm 0.9 , a single inclusion has a ratio close to 1 ) whereas in fractures ratios vary between 0.6 and 1.6 (mean 1.1 \pm 0.4 ). In concretions, higher $\mathrm{CH}_{2} / \mathrm{CH}_{3}$ ratios imply longer aliphatic chains and therefore lower maturity than in fractures. Besides, a correlation is observed between $\mathrm{CH}_{2} / \mathrm{CH}_{3}$ ratios related to oil maturity and fluorescence color: inclusions with a ratio close to 1 show white-blue fluorescence, yellow fluorescence around 2 and orange-brown fluorescence above 2.5. In fractures, predominance of inclusions with with-blue fluorescence over rare 
inclusions with orange-brown fluorescence may indicate greater maturity of oil trapped in fractures, as already suggested by $\mathrm{CH}_{2} / \mathrm{CH}_{3}$ ratios.

Confocal laser scanning microscopy was performed on several petroleum inclusions (features in table 6) to measure oil volume whereas volume of the gas bubble is determined by spherical approximation. Degree of gaseous filling $\left(\mathrm{F}_{\mathrm{v}}\right)$ is used with microthermometry results and thermodynamic modeling to estimate pressure-temperature trapping conditions of petroleum inclusions. $\mathrm{F}_{\mathrm{v}}$ ranges between 3 and $27 \%$ for inclusions in concretions and between 5 and $25 \%$ for inclusions in fractures. $\mathrm{F}_{\mathrm{v}}$ vs $\mathrm{T}_{\mathrm{h}}$ diagram (Fig. 18) is useful to characterize petroleum composition from black oil to dry gas. Oil trapped in concretions falls in the range of heavy black oils and appears to be heavier than oil in fractures, which ranges between black oil and light oil.

Thermodynamic properties and P-T trapping conditions of fluids can be reconstructed with thermometric and compositional data of petroleum and aqueous inclusions. Petroleum isopleths and isochores are represented in figure 19. No aqueous inclusion was observed in the immediate vicinity of modeled oil inclusions. Therefore, aqueous isochores were calculated with contemporaneous inclusion from the same sample and are represented by a band rather than lines. Dashed lines correspond to a "standard" isochore calculated using the mode of $\mathrm{T}_{\mathrm{h}}$ distribution and average salinity. P-T trapping conditions are determined by the intersection of oil and aqueous isochores. In concretions, primary mode hydrocarbon inclusions $\left(\mathrm{Th}<100^{\circ} \mathrm{C}\right)$ indicate trapping temperature between 170 and $190^{\circ} \mathrm{C}$ and trapping pressure between 650 and 750 bars. With secondary mode inclusions $\left(T_{h}>110^{\circ} \mathrm{C}\right)$, 
trapping temperature and pressures range between 150 and $170^{\circ} \mathrm{C}$ and 180 and 280 bars, respectively. In fractures, P-T domains appear to be much more continuous from high pressure to relatively low pressure. Low $T_{h}$ inclusions indicate trapping temperature around $180-190^{\circ} \mathrm{C}$ and pressures between 500 and 600 bars. Most oil inclusions with $\mathrm{T}_{\mathrm{h}}$ above $100^{\circ} \mathrm{C}$ correspond to trapping temperature around 170$180^{\circ} \mathrm{C}$ and trapping pressure between 350 and 430 bars.

Finally, LA-ICPMS analysis of fluid inclusions trapped in calcite did not show any significant concentration in metal or uranium (detection limit of 0.5 to $1 \mathrm{ppm}$ ).

\subsubsection{Impact of burial diagenesis on uranium content: experimental input}

The TOC richest immature sample (from Närke), was heated in gold cells during 24 hours at $350^{\circ} \mathrm{C}$ and 700 bars to simulate thermal maturation and hydrocarbon generation. Pyrolyzed matter was then solvent-extracted. Hydrocarbon extracts and pyrolysis residues were both analyzed and uranium content measured. LA-ICPMS analysis did not allow us to detect any particular uranium content in the solvent extracts (within detection limit). However, residues contain similar, but slightly higher, uranium concentrations, compared to unheated shale (139.9 and $132.4 \mathrm{ppm}$ versus $124.5 \mathrm{ppm})$. TOC values decreased by more than $20 \%$ with hydrocarbon generation, from 18.48 wt.\% to 14.41 and 14.24 wt. \%. Density-corrected values are plotted in figure 6a. Alum Shale samples display a U-constant evolution during thermal maturation.

\subsection{Impact of metamorphism on carbon, sulfur and uranium mineralization}

4.5.1. Organic matter behavior with metamorphism: geothermometer 


\section{application}

The Raman spectrum of carbonaceous matter is composed of several peaks situated in first order $\left(1100-1800 \mathrm{~cm}^{-1}\right)$ and second-order $\left(2500-3100 \mathrm{~cm}^{-1}\right)$ regions (Tuinstra and Koenig, 1970; Nemanich and Solin, 1979). The number, position, width and intensity of peaks depend on the degree of structural organization of carbonaceous material, from very disordered carbonaceous matter to graphite and it can be used as a geothermometer (e.g. Beyssac et al., 2002, 2003(a), 2003(b); Beyssac and Lazzeri, 2012; Lahfid et al., 2010).

In metamorphic Alum Shale samples, organic matter is composed of disseminated pseudo-vitrinite particles and bitumen veinlets in the schist. Bitumen with conchoidal fractures can also be found in veins, trapped in calcite (Fig. 7c to f). Raman spectroscopy of carbonaceous material (RSCM) was applied on different metamorphic samples from the Caledonian front (Tåsjö and Myrviken), in order to characterize the degree of organization of organic matter and estimate metamorphic temperature. Both pseudo-vitrinite and bitumen have been studied and Raman data are provided in table 7. Organic material in the Alum Shale shows first-order and second-order regions corresponding to very disordered carbonaceous matter (Fig. 20a). We thus applied a fitting procedure using five bands with Lorentzian profiles (Lahfid et al., 2010; Lecomte et al., 2014). The decomposed first-order region of carbonaceous matter spectrum (Fig. 20b) is composed of a predominant graphite peak including a graphite band s.s. (G) at $1595 \pm 3 \mathrm{~cm}^{-1}$ and a defect band (D2) at $1608 \pm 3 \mathrm{~cm}^{-1}$, and a secondary composite (D) peak with major defect band (D1) at $1332 \pm 2 \mathrm{~cm}^{-1}$ and a left shoulder (defect band (D4) at $1218 \pm 9 \mathrm{~cm}^{-1}$ ). In disordered CM, intensity of the valley between (D1) and (G) is high and indicates the existence of 
another band (D3) at $1513 \pm 8 \mathrm{~cm}^{-1}$.

Following procedure described by Lahfid et al. (2010), using two area ratios $\mathrm{RA} 1=(\mathrm{D} 1+\mathrm{D} 4) /(\mathrm{D} 1+\mathrm{D} 2+\mathrm{D} 3+\mathrm{D} 4+\mathrm{G})$ and $\mathrm{RA} 2=(\mathrm{D} 1+\mathrm{D} 4) /(\mathrm{D} 2+\mathrm{D} 3+\mathrm{G})$ yield an estimate of the maximal temperature that underwent the organic matter: RA1 $=0.0008 \mathrm{~T}+0.3758$ and $\mathrm{RA} 2=0.0045 \mathrm{~T}+0.27$ (Table 7$).$ In metamorphic Alum Shale, calculated temperatures are slightly higher at Tåsjö $\left(305 \pm 11^{\circ} \mathrm{C}\right.$ with RA1 and $302 \pm 14^{\circ} \mathrm{C}$ with RA2) than at Myrviken $\left(285 \pm 11^{\circ} \mathrm{C}\right.$ with RA1 and $279 \pm 13^{\circ} \mathrm{C}$ with RA2). In such low-grade metamorphic systems, temperature is considered to be the key parameter for carbonaceous matter evolution at geological time scales even if other parameters (pressure, time or deformation) are less well constrained (Beyssac et al., 2003(a); Lahfid et al., 2010).

\subsubsection{Modification of sulfide paragenesis}

In metamorphic Alum Shale from the Caledonian front, all pyrites generations described in immature shales (Py1 to Py5) have been affected by metamorphism during Caledonian orogeny. Several particular modifications can be identified, namely: (a) intense fracturing throughout the Alum Shale, with pyrite and calcite fillings, and numerous pyrite overgrowths (Fig. 21a and b). In particular, these overgrowths are much more frequent in metamorphic samples than in immature ones, and occur not only in fractures but also around previous pyrite generations, often completely cataclased by deformation. These secondary crystals can reach several tens of microns and calcite precipitates in pressure shadows around massive pyrites; (b) plastic deformation of pyrite beds (framboids and small euhedral crystals), initially parallel to stratification (Fig. 21c); (c) pressure-solution features on 
small euhedral pyrites, with interpenetrating grain boundaries (Fig. 21d); (d) precipitation of new sulfides (chalcopyrite and sphalerite) coexisting with late pyrite after fracturing stage. Chalcopyrite and sphalerite generally occurs as cements around euhedral pyrites or as fracture fillings (Fig. 21e to h).

In metamorphic Alum Shale, the latest pyrite generation (named Py6), which is sub-synchronous with chalcopyrite and sphalerite, is enriched in $\mathrm{Ni}, \mathrm{As}$, Se and Cd compared to synsedimentary pyrites (Fig. 12c and d). Besides, early pyrites, and in particular framboids, preserved their trace elements signature, which is emphasized by $(\mathrm{Cu}, \mathrm{As}, \mathrm{Ni})$-rich clusters in massive pyrites. Isotopic analyses on late metamorphic pyrites yield $\delta^{34} S$ values between 9 and 15\%o (Fig. 13).

\subsubsection{Uranium mineralogical expression and metamorphism}

Apatite- $(\mathrm{CaF}[\mathrm{OH}])$ nodules can also be found in metamorphic Alum Shale, but they are more porous than in non metamorphic samples (Fig. 14e). Bell-shaped REE spectra are flattened with a preferential enrichment in light and heavy REE (La, Ce, $\mathrm{Tm}, \mathrm{Yb}, \mathrm{Lu}$ ) compared to middle REE (Fig. 15b). Some of them display a negative anomaly in Eu. Besides, whereas uranium concentration in non metamorphic shales does not exceed a few hundreds ppm, it can reach several thousands ppm uranium in metamorphic black schists (between 322 and 2655 ppm uranium).

As previously mentioned, no detectable uranium mineral was observed in immature Alum Shale. On the contrary, in metamorphic Alum Shale, two types of uranium bearing-minerals were detected: (a) uraninite and uranium titanate microinclusions in synmetamorphic pyrites (Fig. 22a and b); (b) complex assemblages of $U$, $\mathrm{Ti}$, and $\mathrm{Y}$ phospho-silicates (Fig. 22c to f). In details, preserved uraninites and 
uranium titanates are rare and can only be found in euhedral pyrites and overgrowths associated with retrograde metamorphism. These pyrites are the latest to crystallize around preexisting sulfides and pyrobitumens (Lecomte et al., 2013). On the contrary, uranium phospho-silicates are frequently found disseminated in the organo-mineral matrix or in patches around pyrobitumen veins, pseudo-vitrinite particles or pyrite. Uranium phospho-silicates seem to crystallize essentially at the periphery of carbonaceous particles and on pyrite framboids. Rare occurences show particular textures with uraninite or urano-titanates cores rimmed by U-Ti phosphosilicates. Corrosion gulfs around these U-Ti oxides are also filled with U-Ti phosphosilicates. Spherolites of uranium phospho-silicates were also found in apatite$(\mathrm{CaF}[\mathrm{OH}])$ nodules. In metamorphic Alum Shale, these porous phosphates nodules are often surrounded by pyrobitumen. Uranium minerals have been analyzed with electronic microprobe and standard-calibrated SEM (Table 8). All these phosphosilicate clusters correspond to phosphocoffinites with variable $\mathrm{Ti}, \mathrm{Y}, \mathrm{Zr}$ content.

Uranium phospho-silicates have variable analytical totals between 70 and 98.33 wt.\%. Low analytical totals in (phospho)-coffinite are probably related to micro-porosity or hydratation (Deditius et al., 2008). Atoms per formula units (APFU) of $\mathrm{Si}, \mathrm{P}, \mathrm{Ca}, \mathrm{Pb}$, $\mathrm{Ti}, \mathrm{U}, \mathrm{Y}$ and $\mathrm{Zr}$ in uranium minerals were calculated on the basis of two oxygens and one cation (Table 8). Three groups can be separated based on $\mathrm{Y}$ and Ti concentration: (a) Y-poor/Ti-rich phospho-silicates (“Brannerite” group); (b) Y-poor/Ti-poor phospho-silicates (“Uraninite” group); (c) Y-rich/Ti-poor phospho-silicates ("Xenotime" group), including micro-spherolites apatite-(CaF[OH]) nodules. In 
figure 23, $\mathrm{Ti}$ and $\mathrm{U}+\mathrm{Pb}+\mathrm{Zr}$ concentrations are plotted against $\mathrm{Si}$ and $\mathrm{P}$ content, respectively. Uraninite $\left(\mathrm{UO}_{2}\right)$, brannerite $\left(\mathrm{U}_{0,33} \mathrm{Ti}_{0,66} \mathrm{O}_{2}\right)$, coffinite $\left(\mathrm{U}_{0,5} \mathrm{Si}_{0,5} \mathrm{O}_{2}\right)$ and xenotime $\left(\mathrm{Y}_{0,5} \mathrm{P}_{0,5} \mathrm{O}_{2}\right)$ are also indicated. $\mathrm{Pb}$ and $\mathrm{Zr}$ content is low and these two elements are substituted for $\mathrm{U}$ in phospho-silicates. $\mathrm{Pb}$ and $\mathrm{Zr}$ will thus be considered with $\mathrm{U}$ concentration in successive graphs. Y-poor/Ti-rich phosphosilicates are aligned between "brannerite" and "coffinite" end-members, the former corresponding to well-preserved U-Ti oxides micro-inclusions in pyrite. Y-poor/Tipoor phospho-silicates are aligned between "uraninite" and "coffinite" endmembers, the former corresponding to well-preserved $\mathrm{U}$ oxides micro-inclusions in pyrite; the gap between analyses and theoretical evolution is caused by the presence of calcium in U phospho-silicates. Y-rich/Ti-poor phospho-silicates are aligned between "brannerite" and "coffinite" end-members, the former corresponding to rare $\mathrm{YPO}_{4}$ crystals. Ca content is generally constant, whatever the concentration in $\mathrm{Si}$, but increases along with $\mathrm{P}$, only in the case of Y-poor/Ti-poor phospho-silicates ("uraninite").

\section{Discussion}

\subsection{Sedimentation and uranium preconcentration}

Sulfur, mainly present as sulfide, and organic carbon contents (Fig. 5a) provide different information on conditions of sedimentation for the Alum Shale of Sweden. In Carbon-Sulfur plots, marine sediments deposited in oxygenated waters display a positive correlation fitting the origin of the diagram. Indeed, pyrite precipitation occurs below the sediment-water interface and is limited by the 
concentration of organic carbon (Berner and Raiswell, 1983). On the contrary, sediments deposited in euxinic conditions would not display any correlation or would have a positive intercept with the total sulfur axis (Raiswell and Berner, 1985). This positive intercept represents the formation of pyrite in the water column and at the sediment-water interface, regardless of the organic carbon content. The slightly positive correlation line and the presence of data points in the "normal marine sediments" field can be explained by euxinic conditions, but where pyrite precipitation is limited by the concentration of available iron (Lyons and Berner, 1992; Leventhal, 1995). Besides, the evolution of the $\mathrm{V} / \mathrm{Cr}$ ratio as a function of $\mathrm{V} /(\mathrm{V}$ $+\mathrm{Ni}$ ) allows characterizing the level of oxygenation during sedimentation (Jones and Manning, 1994; Hatch and Leventhal, 1992). For the Alum Shale Formation (Fig. 5b), $\mathrm{V} / \mathrm{Cr}$ and $\mathrm{V} /(\mathrm{V}+\mathrm{Ni})$ ratios indicate sedimentation in suboxic to anoxic conditions.

During sedimentation, organic matter was accumulated as fluorescent liptinite macerals and non-fluorescent pseudo-vitrinite macerals. However, vitrinite derived from humification of vascular plants cannot exist in pre-silurian sediments. In fact, pseudo-vitrinite is frequently observed in Cambrian Scandinavian shales (Kisch, 1980, Buchardt et al., 1990) or in Tarim basin sediments (China) and may originate from multicellular benthic algae (Wang, 2000). In the Alum Shale Formation, pseudovitrinite and graptolites display identical reflectance, which suggests that vitrinitelike particles may in fact be fragments of graptolites (Petersen et al., 2013). Therefore, petrographic observations are consistent with Rock-Eval analyses and support organic matter accumulation in marine settings (Type II kerogens, Figures 8 and 9).

In the Alum Shale Formation, five successive pyrite generations (Py1 to Py5, 
Fig. 13) precipitated during sedimentation and diagenesis. No particular traceelement enrichment was measured in pyrites, which may indicate similar geochemical conditions or low availability in interstitial fluids during sulfide precipitation. High $\mathrm{Cu}$ and As content in framboids may be linked to specific affinity of some trace elements $(\mathrm{Mo}, \mathrm{As}, \mathrm{Cu})$, due to fast nucleation and high specific surface of framboids.

The wide spread of $\delta^{34} S$ values in syn-sedimentary to syn-diagenetic pyrites (-10 to $+40 \%$; data from Dahl, 1990 and this study in Fig. 13) together with the existence of negative values suggest the implication of bacterial processes resulting in sulfate reduction and sulfide precipitation (Fig. 24).

When looked in details, disseminated framboids display negative $\delta^{34} S(-4 \%$ o measured in this study). Negative values measured by Dahl (1990) on whole-rock pyrites may thus be explained by the predominance of framboids over other pyrites generations. Bacterial sulfate reduction (BSR) is known to produce ${ }^{32}$ S-rich sulfides compared to initial sulfate (Goldhaber et al., 1978). Indeed, while inorganic sulfate reduction yield a 22\% sulfate-sulfide isotope fractionation (Harrison and Thode, 1958), bacterial pathway is responsible for higher fractionation, up to $46 \%$ on bacterial cultures (Kaplan and Rittenberg, 1964) and 40\%o in sediments (Habicht and Canfield, 2001 ; Canfield, 2001). Considering a $\delta^{34} S$ value of about 30\%o for initial sulfate [ $\delta^{34} \mathrm{~S}$ of $\mathrm{SO}_{4}{ }^{2-}$ in marine Cambrian waters (Claypool et al., 1980; Strauss, 1997), the most likely sulfate source for early pyrites], such fractionation brings in $\delta^{34} S$ down to $-15 \%$. Unlike disseminated framboids, cogenetic euhedral pyrites and cemented framboids clusters form beds parallel to shale stratification and show 
highly positive $\delta^{34} S$, above $\delta^{34} S$ of sulfate in marine Cambrian waters. Theoretically, sulfate supply and availability are the main processes affecting isotope variability in sedimentary sulfides. Indeed, considering an open system in which sulfate reservoir is permanently replenished, isotope fractionation remains constant and yield to negative $\delta^{34} S$ in the case of predominant bacterial sulfate reduction. On the contrary, in a closed system, reduction of sulfate pool to sulfides preferentially removes ${ }^{32} \mathrm{~S}$ and thus enriches residual sulfate in ${ }^{34} \mathrm{~S}$. Sulfides show higher and higher $\delta^{34} \mathrm{~S}$ which tend towards value of starting sulfate. However, even in an ideally closed system, sulfide $\delta^{34} S$ cannot exceed $\delta^{34} S$ of initial sulfate, due to mass conservation between ${ }^{32} \mathrm{~S}$ and ${ }^{34} \mathrm{~S}$ once sulfate is depleted. Jørgensen (2004) even considers that such a distinction between open and closed systems cannot be applied to marine sediments because: (a) it passes over vertical diffusion processes of $\mathrm{SO}_{4}{ }^{2-}$ and $\mathrm{H}_{2} \mathrm{~S}$ in the sediment, and particularly the fact that isotope ratios of these fluxes differ from those of $\mathrm{SO}_{4}{ }^{2-}$ and $\mathrm{H}_{2} \mathrm{~S}$ reservoirs at different depths; (b) most present-day sediments used as analogues, including in anoxic closed basins such as Black Sea, cannot be considered as truly closed systems because they are never completely isolated from seawater sulfate reservoir. Moreover, in the case of the Alum Shale Formation, precipitation of disseminated framboids or micro-pyrites, beds of euhedral pyrites and framboids clusters is probably very early, in the water column, at watersediment interface or within first centimeters of the sediment. Therefore, isotope composition of sulfides precipitated in sediment and in particular progressive $\delta^{34} S$ enrichment do not seem to be related to the development of a closed system, but rather to fractionation and vertical diffusion of $\mathrm{SO}_{4}{ }^{2-}$ and $\mathrm{H}_{2} \mathrm{~S}$ with a $\delta^{34} \mathrm{~S}$ enrichment 
of interstitial water sulfates. This model is based on isotopic measurement of sulfides from the Black Sea, in which pyrites that precipitated in the water column have positive $\delta^{34} S$, sometimes close to $\delta^{34} S$ of initial sulfate pool (Lyons and Berner, 1992; Wilkin and Arthur, 2001). Jørgensen (2004) thus demonstrated important $\delta^{34} S$ enrichment of $\mathrm{SO}_{4}{ }^{2-}$ and $\mathrm{H}_{2} \mathrm{~S}$ toward sediment depth. This is not related to the development of a closed system s.s. but to a steeper gradient for ${ }^{32} \mathrm{~S}$ than for ${ }^{34} \mathrm{~S}$, which yields larger ${ }^{32} \mathrm{~S}$ depletion and thus ${ }^{34}$ S-rich remaining sulfate at depth. Such a process may generate sulfates with extreme $\delta^{34} S$, up to $+135 \%$ o 40 meters below sediment-water interface (Rudnicki et al., 2001). Moreover, elevated gradients can yield $\delta^{34}$ S increase of $40 \%$ within 2-3 meters and 70\%o within 15-20 meters in the sediment. On the contrary, $\mathrm{H}_{2} \mathrm{~S}$ gradient is steeper for $34 \mathrm{~S}$ than for ${ }^{32} \mathrm{~S}$. These gradients have important consequences for sulfate and sulfide diffusion in the sediment (Jørgensen, 1979; Goldhaber and Kaplan, 1980; Chanton et al., 1987). Indeed, compared with interstitial waters at the same depth, downward $\mathrm{SO}_{4}{ }^{2-}$ flux is enriched in ${ }^{32} \mathrm{~S}$ and upward $\mathrm{H}_{2} \mathrm{~S}$ flux is enriched in ${ }^{34} \mathrm{~S}$. This differential diffusion, although limited in comparison with sulfate and sulfide concentrations in modern sediments (Jørgensen, 2004) implies: (1) ${ }^{32}$ S transfer toward depth and therefore limitation of $\delta^{34} S$ increase in deep sulfates; (2) light sulfide conservation at depth and heavy $\mathrm{H}_{2} \mathrm{~S}$ flux toward surface. The behavior and evolution of isotopic ratios sulfates and sulfides in sediments is a complex system that cannot be reduced to the differentiation between an open system and closed system.

In the Alum Shale Formation, with an increase in the first meters of the sediment as previously described, $\delta^{34} S$ values of interstitial water sulfates may reach 
70 to $80 \%$, and lead to high $\delta^{34} S$ in sedimentary pyrites through bacterial sulfate reduction (30-40\% in pyrite clusters and beds of first generation). In that case, framboids with negative $\delta^{34} S$ should be considered as the earliest pyrites precipitated through BSR in the water column or at the sediment-water interface, from a primary sulfate pool (seawater sulfate). Second and third pyrite generations have close $\delta^{34} S$ values between 18 and 26\%o, lower than early pyrites. Petrographically, some of these pyrites correspond to recrystallization of cemented early pyrites, and their signature may therefore be a mixing between negative $\delta^{34} S$ of framboids and high $\delta^{34} S$ of euhedral pyrites. The large pyrite crystals, which remain disseminated in the shale or grow perpendicular to some pyrite band and form centimeter-scale beds and nodules, have very similar $\delta^{34} S$ around $24-25 \%$. Besides, no differences in isotope ratio were measured between the base (or core) and the top (or edge) of the crystals, which would indicate a homogeneous growth phase. However, a massive pyrite with an early pyrite inclusion display a $\delta^{34} S$ increase from core to rim (16 to $23 \%$ o). Therefore, after crystallization of high- $\delta^{34} S$ primary pyrites $\left(\delta^{34} S=30-40 \%\right.$ ), a phase of cementation and crystal growth occurred, with $\delta^{34} S$ around $15-16 \%$. This phase is followed by progressive $34 \mathrm{~S}$ enrichment of residual sulfate, either locally through closed system Rayleigh fractionation or with sulfate $\delta^{34} S$ increase with depth. The fourth pyrite generation, which correspond to massive pyrite cementation, may be the end of ${ }^{34} \mathrm{~S}$ enrichment process with $\delta^{34} \mathrm{~S}$ around $30-31 \%$, close to that of sulfates in Cambrian marine waters.

Although $\delta^{34} S$ evolution of pyrite generation can be explained by progressive enrichment of sulfates in $34 S$, the $15-25 \%$ drop of $\delta^{34} S$ between early pyrites 
precipitated in the sediment and the second generation of pyrite, which cements detrital grains and early pyrites, remains unclear. Considering similar isotope fractionation for the first four generations precipitated in non-indurated sediment, the best explanation implies supply of light sulfate from overlying seawater during reworking of superficial sediment, which would have brought a $20 \%$ decrease of the ¿34S of interstitial water sulfate. In the same way, the fifth generation of pyrite is characterized by a $10 \%$ drop of the $\delta^{34}$, although being the latest generation in a general trend of increasing $\delta^{34} S$. These pyrites, which correspond to fracture fillings in the shale and overgrowths in fractures within massive pyrites, precipitated during late diagenesis at temperatures between 50 and $100-120^{\circ} \mathrm{C}$ (maximum temperature indicated by fluorescence colors of macerals). One possible explanation involves light $\mathrm{H}_{2} \mathrm{~S}$ generated by kerogen thermal maturation in the most mature Alum Shale (Amrani et al., 2005). Besides, bacterial activity and bacterial sulfate reduction is generally possible at temperatures below $80^{\circ} \mathrm{C}$ (Machel, 2001), and rarely up to $110^{\circ} \mathrm{C}$ (Jørgensen, 1992). Considering, maximum temperatures suggested by kerogens, it is thus necessary to take into account potential influence of thermochemical sulfate reduction (TSR) occurring at temperatures above $100^{\circ} \mathrm{C}$ (Machel, 2001; Basuki et al., 2008). TSR can theoretically yield isotope fractionation between 0 and -20\%o (Machel, 1995). Indeed, whereas TSR experimental reproduction brings fractionation between 10 and 20\%o (Harrison and Thode, 1957; Kiyosu and Krouse, 1990), in most sedimentary deposits no fractionation is measured (Krouse, 1977; Orr, 1977; Worden and Smalley, 1996; Cai et al., 2001). Therefore, the last generation of pyrite may also precipitate through TSR of sulfates showing a $\delta^{34}$ S around $20-30 \%$. 
In immature Alum Shale, uranium mineralization has no expression as even discrete mineral phases. However, uranium concentration is positively correlated with organic carbon content (Fig. 6a) and phosphorus concentration (Fig. 6b), indicating a specific association where uranium shows a dissemination and/or a complexation with organic matter or phosphates. Such a close relationship was previously suggested by several studies on $k o l m$, organic matter lenses containing up to several thousands ppm uranium, in particular in cerium-bearing minerals (Cobb and Kulp, 1961; Armands, 1972; Parnell, 1984).

The correlation between phosphorus and uranium contents in Alum Shale is linked to the existence of a major uranium-bearing phase as calcium phosphate nodules. These apatite- $(\mathrm{CaF}[\mathrm{OH}])$ nodules are disseminated in the black shale and show typical bell-shaped REE patterns, with a strong enrichment in middle REE. This type of pattern is common in marine sediments, particularly in pre-Jurassic biogenic phosphates, and can be explained by two successive processes: an adsorption mechanism during early diagenesis and a substitution mechanism associated with recrystallization during late diagenesis (Reynard et al., 1999). These apatite- $(\mathrm{CaF}[\mathrm{OH}])$ nodules contain 100 to $3000 \mathrm{ppm}$ uranium and therefore constitute an important part of uranium mineralization (Fig. 25). However, the projection of whole-rock $\mathrm{U}$ concentration to the $18 \%$ phosphorus content typical of apatite, indicates that apatite in the Alum Shale could contain up to $1500 \mu \mathrm{g} . \mathrm{cm}^{-3}$ uranium (i.e. around $600 \mathrm{ppm} \mathrm{U}$ ). This result suggests that only uranium content below $600 \mathrm{ppm}$ in phosphate nodules corresponds to the primary homogeneous preconcentration associated with sedimentation and diagenesis, whereas higher 
values may indicate local reconcentration as phosphosilicate spherolites (Fig. 25).

\subsection{Burial and thermal maturation}

During burial and thermal maturation, Alum Shale generated hydrocarbons that were trapped as fluid inclusions in carbonate levels within the black shale and in fractured Ordovician limestones. Petroleum and aqueous isochores indicate high trapping temperature $\left(>150^{\circ} \mathrm{C}\right)$ and extremely variable trapping pressure, from 700 bars for low- $\mathrm{T}_{\mathrm{h}}$ inclusions to 200 bars for high- $\mathrm{T}_{\mathrm{h}}$ inclusion (Fig. 26). Besides, P-T domains seem to be aligned in a rather similar temperature range, which may suggest isothermal decompression during calcite crystallization. Several theoretical pathways are indicated on figure 26. First hypothesis considers an underestimated burial with low geothermal gradient $\left(<20^{\circ} \mathrm{C} / \mathrm{km}\right)$, consistent with present-day foreland basin gradients and suggested by Huigen and Andriessen (2004) for the Caledonian foreland basin. In that case, high pressures could be reached but at temperatures below $100^{\circ} \mathrm{C}$. Second hypothesis uses a normal geothermal gradient to obtain high pressure/high temperature conditions. Finally, a third hypothesis considers a low burial to explain low trapping pressure of most inclusions in concretions, but precludes high pressure conditions.

Alum Shale in central Sweden (Västergötland, Östergötland, Närke) is immature and did not encountered temperatures above $90-100^{\circ} \mathrm{C}$. Besides, Alum Shale burial is mainly related to the development of a Silurian-Devonian foreland basin during Caledonian orogeny (Ziegler, 1988; Middleton et al., 1996). Basin modeling (Samuelson and Middleton, 1998, 1999) indicates a 2 kilometers deep maximum burial in central Sweden (Västergötland, Närke). Since the Caledonian 
foreland basin gets thinner eastward, maximum burial during the Devonian ranges between 1 and 2 kilometers at Åland (Cederbom, 1997 and Larson et al., 1998, cited in Larson et al., 1999). The initial uplift, probably starting in the Devonian, is faster in the western part of the basin. This implies lateral redistribution of the sediments which leads to a rather uniform 2 kilometers deep basin infill around $250 \mathrm{Ma}$ (Larson et al., 1999). Therefore, Alum Shale burial in central Sweden never exceeded 2 kilometers in the Devonian, and probably less in the Ordovician, because most postCambrian accumulated sediments correspond to foreland basin filling during the Silurian-Devonian period. U-Pb dating of cone-in-cone calcite indicates that formation of late concretions in the Upper Cambrian Alum Shale took place during Early Ordovician (Israelson et al., 1996) at relatively limited depth. By analogy with present-day geothermal gradients in hypothermal foreland basins and considering the thermal age of basement rocks (Huigen and Andriessen, 2004), a low paleogeothermal gradient of $20^{\circ} \mathrm{C} / \mathrm{km}$ seems to be realistic and implies that temperature reached by most immature Alum Shale may not have exceeded a few tens of degrees. Since concretions and fractures are pre-Permian, local thermal maturation related to Permian dolerite intrusions cannot be considered as a major process of hydrocarbon generation. Moreover, thermal influence of intrusions on Alum Shale is limited to a few tens of meters (30 meters at Kinnekulle according to Samuelsson and Middleton, 1999), which excludes any significant influence of Permian intrusions on regional heating at the end of the Palaeozoic (Tullborg et al., 1996; Larson et al., 1998).

Although it is not possible to completely rule out either overestimation of P-T trapping conditions because of inclusion volume modification or underestimation of 
maximum burial in particular considering extremely low thermal gradient, it seems to be clear that theoretical pathways are unachievable with foreland basin evolution and that formation of calcite concretions and fractures is related to the circulation of overpressured and overheated fluids. Such concretions, described as beddingparallel veins or beefs, are indeed widespread in low-permeability strata in sedimentary basins and generally contain solid or liquid hydrocarbons. Beefs may be the result of fluid overpressure linked to petroleum generation (Cobbold et al., 2013; Rodrigues et al., 2009). To explain the existence of beefs, concretions, breccias and fractures containing hydrocarbons in immature areas, it is necessary to consider contemporaneous migration of hydrocarbons and brines from mature and overmature Alum Shale to immature Alum Shale. In that model, overpressure allows fracture opening and calcite precipitation, which in turn induce fluid pressure drop. These regional migrations are already active in the Ordovician and lead to primary beef formation. First inclusions contain black oils with orange-brown fluorescence and formed at high pressure $(>500$ bars $)$ and high temperature $\left(>150^{\circ} \mathrm{C}\right)$. Second assemblage is characterized by a higher proportion of mature oils with white-blue fluorescence. These inclusions are associated with numerous brine inclusions and have been trapped around $150-170^{\circ} \mathrm{C}$ and 200 bars. This pressure drop is interpreted as a decompression after fracture opening. Beefs have been locally dislocated and reworked as breccias. Angular calcite particles preclude long-distance transport and may suggest insitu reworking. Such breccias have only been observed at Öland, in a more proximal environment than Västergötland or Närke. Fracture fillings in Ordovician limestones are later. The presence of monophasic oil inclusions at room 
temperature indicates high pressure trapping. Low- $\mathrm{T}_{\mathrm{h}}$ inclusions have been trapped at high pressure between 600 and 700 bars and temperatures around $200^{\circ} \mathrm{C}$, whereas high- $\mathrm{T}_{\mathrm{h}}$ inclusions have been trapped around 400 bars and $170-180^{\circ} \mathrm{C}$. Therefore, fluid inclusions have recorded a major pressure drop of several hundreds of bars between first opening of fractures by overpressured hydrocarbons and brines and the final sealing. Temperature decrease is probably related to fluid cooling during calcite precipitation within a rather cold host rock.

However, these fluids do not contain significant uranium concentration (see section 4.4.1). Thermal maturation simulation (Dahl, 1990; this study) shows that uranium remains immobile during maturation. In the meantime, carbon loss reaches up to $10 \%$ or more ( $22 \%$ in this study) with the formation of $10 \%$ residual carbon (Horsfield et al., 1992). Thus, carbon loss during thermal maturation of Alum Shale leads to a relative enrichment in uranium due to rock density changes in response to the carbon loss, which may partly explain the steeper slope of the correlation line in metamorphic samples compared to immature samples.

\subsection{Uranium remobilization during metamorphism}

During Caledonian orogeny, Alum Shale has been heated up to $305 \pm 11^{\circ} \mathrm{C}$, as recorded by organic material. This temperature corresponds to sub-greenshist metamorphic facies, as previously suggested by Kisch (1980).

During metamorphism, uranium preconcentration is remobilized and cristallized as uraninite or uranotitanate. Some micro-crystals remain preserved from alteration as inclusions in metamorphic pyrites. Outside pyrites, uraninites and urano-titanates are now replaced by U-Ti phospho-silicates clusters or rims around 
U-Ti oxides primary cores. These phospho-silicates contain $\mathrm{U}, \mathrm{Ti}, \mathrm{Y}, \mathrm{Zr}, \mathrm{Pb}$ with highly variable concentrations and can be gathered in three chemical groups: a) Ypoor/Ti-rich phospho-silicates (“Brannerite” group); (b) Y-poor/Ti-poor phosphosilicates ("Uraninite" group); (c) Y-rich/Ti-poor phospho-silicates ("Xenotime" group). These distinct U-Ti phospho-silicate series result from silicification and/or phosphorization of different mineral precursors, which can rarely be found preserved throughout the Alum Shale. Y-poor/Ti-rich phospho-silicates result from the silicification of brannerite. Silicification comes along a drop in Ti content, associated with $\mathrm{TiO}_{2}$ crystallization, whereas $\mathrm{U}$ concentration remains constant. Ypoor/Ti-poor phospho-silicates result from the silicification of uraninite, with $\mathrm{U} \leftrightarrow \mathrm{Ca}$ and $\mathrm{Si} \leftrightarrow \mathrm{P}$ substitutions. In this series, $\mathrm{Y}$ concentration remains low. Finally, Y-rich/Ti-poor phospho-silicates result from the silicification of Y-phosphate, with $\mathrm{Y} \leftrightarrow \mathrm{U}$ and $\mathrm{P} \leftrightarrow \mathrm{Si}$ substitutions. During Greenschist facies metamorphism, uranium can also be redistributed in sedimentary apatite- $(\mathrm{CaF}[\mathrm{OH}])$ nodules. $U$ concentrations above $600 \mathrm{ppm}$ thus correspond to reconcentration areas with local crystallization of phosphosilicate micro-spherulites.

\section{Conclusions}

Scandinavian Alum Shale is among the most uraniferous black shale units throughout Earth history and extends over most of northern Europe. As in many other black shales, uranium was preconcentrated during sedimentation. In the Alum Shale Formation, uranium primary accumulation occurred in organic matter and biogenic marine phosphate nodules. Besides, it is clear that primary concentration 
has not been affected by early burial, thermal maturation of organic matter and petroleum generation. Migrating fluids in the Alum Shale Formation did not carry any particular uranium content. However, uranium was remobilized during Greenschist facies metamorphism of Caledonian orogeny and crystallized as uraninite and brannerite minerals. Rare remnants of this crystallization stage are found as micro-inclusions in syn-metamorphic pyrites. Most of mineralization actually evolved to complex U-Ti phospho-silicates, as clusters associated with carbonaceous matter or spherulites inside biogenic phosphate nodules.

This work shows that, despite its relatively high synsedimentary preconcentration, uranium remains immobile through the stages of diagenesis, burial and thermal maturation. However, pressure-temperature conditions reached during Caledonian orogeny are high enough to favor new uranium speciation as U-Ti oxides and phospho-silicates. The knowledge of uranium mineralogy and its particular association with phosphates is crucial to assess potential extraction feasibility and adjust recovery processes. This result is also of great interest for the oil and gas companies prospecting hydrocarbons in southern Sweden Alum Shale. Thus, uranium could be considered to have a potential penalizing effect on the quality of released waters during the gas recovery by hydrofracturing. But, as it occurs up to the oil window as poorly soluble phosphates, the risks of potential water contamination by radionuclides are probably minimized.

\section{Acknowledgments}

The authors would like to thank M. Hudson (Mawson Resources) and C. 
Caillat (AREVA) for helping us during this study and for their assistance during the field trip in Sweden. We are grateful to the Geological Survey of Sweden (SGU), especially L. Hildebrand and L. Wickström, for welcoming us in Malå and Uppsala and for their technical assistance in the sampling process. We acknowledge Niels $\mathrm{H}$. Schovsbo for his useful comments and suggestions.

This work was supported by Institut Carnot Énergie et Environnement en Lorraine (ICEEL), Labex Ressources 21 (supported by the French National Research Agency through the national program "Investissements d'avenir", reference ANR-10-LABX21-LABEX RESSOURCES 21) and AREVA. 


\section{References}

Amrani, A., Lewan, M.D., Aizenshtat, Z., 2005. Stable sulfur isotope partitioning during simulated petroleum formation as determined by hydrous pyrolysis of Ghareb Limestone, Israel. Geochimica et Cosmochimica Acta 69, 53175331

Andersson, A., Dahlman, B., Gee, D.G., Snäll, S., 1985. The Scandinavian Alum Shales. Sveriges Geologiska Undersökning, Uppsala.

Armands, G., 1972. Geochemical studies of uranium, molybdenum and vanadium in a Swedish alum shale. Stockholm University.

Berner, R.A., Raiswell, R., 1983. Burial of organic carbon and pyrite sulphur in sediments over Phanerozoic time: a new theory. Geochimica et Cosmochimica Acta 47, 855- 862.

Beyssac, O., Brunet, F., Petitet, J.-P., Goffé, B., Rouzaud, J.-N., 2003a. Experimental study of the microtextural and structural transformations of carbonaceous materials under pressure and temperature. European Journal of Mineralogy $15,937-951$.

Beyssac, O., Goffé, B., Chopin, C., Rouzaud, J.N., 2002. Raman spectra of carbonaceous material in metasediments: a new geothermometer. Journal of Metamorphic Geology 20, 859-871.

Beyssac, O., Goffé, B., Petitet, J.-P., Froigneux, E., Moreau, M., Rouzaud, J.-N., 2003b. On the characterization of disordered and heterogeneous carbonaceous materials by Raman spectroscopy. Spectrochimica Acta Part A: Molecular and Biomolecular Spectroscopy 59, 2267-2276. 
Beyssac, O., Lazzeri, M., 2012. Application of Raman spectroscopy to the study of graphitic carbons in the Earth Sciences, in: Dubessy, J., Caumon, M.-C., Rull, F. (Eds.), Applications of Raman Spectroscopy to Earth Sciences and Cultural Heritage, EMU Notes in Mineralogy. European Mineralogical Union and the Mineralogical Society of Great Britain \& Ireland, pp. 415-454.

Buchardt, B., Schovsbo, N.H., Nielsen, A.T., 1997. Alun skiferen i Skandinavien. Geologisk Tidsskrift 3, 1-30.

Canfield, D.E., 2001. Isotope fractionation by natural populations of sulfate-reducing bacteria. Geochimica et Cosmochimica Acta 65, 1117-1124.

Cederbom, C., 1997. Fission track thermochronology applied to Phanerozoic thermotectonic events in central and southern Sweden. PhD Thesis, Earth Sciences Centre, Göteborg University, Earth Sciences Centre.

Chanton, J.P., Martens, C.S., Goldhaber, M.B., 1987. Biogeochemical cycling in an organic-rich coastal marine basin. 8. A sulfur isotopic budget balanced by differential diffusion across the sediment-water interface. Geochimica et Cosmochimica Acta 51, 1201-1208.

Claypool, G.E., Holser, W.T., Kaplan, I.R., Sakai, H., Zak, I., 1980. The age curves of sulfur and oxygen isotopes in marine sulfate and their mutual interpretation. Chemical Geology 28, 199-260.

Cobb, J.C., Kulp, J.L., 1961. Isotopic geochemistry of uranium and lead in the Swedish kolm and its associated shale. Geochimica et Cosmochimica Acta $24,226-249$.

Cobbold, P.R., Zanella, A., Rodrigues, N., Løseth, H., 2013. Bedding-parallel fibrous 
veins (beef and cone-in-cone): Worldwide occurrence and possible significance in terms of fluid overpressure, hydrocarbon generation and mineralization. Marine and Petroleum Geology 43, 1-20.

Dahl, J., 1990. The organic geochemistry of the Alum Shale, Sweden. University of California, Los Angeles.

Deditius, A.P., Utsunomiya, S., Ewing, R.C., 2008. The chemical stability of coffinite, $\mathrm{USiO}_{4} \mathrm{nH}_{2} \mathrm{O} ; 0<\mathrm{n}<2$. Chemical Geology 251, 33-49.

Dubessy, J., Lhomme, T., Boiron, M.-C., Rull, F., 2002. Determination of Chlorinity in Aqueous Fluids Using Raman Spectroscopy of the Stretching Band of Water at Room Temperature: Application to Fluid Inclusions. Applied Spectroscopy 56, 99-106.

Goldhaber, M.B., Kaplan, I.R., 1980. Mechanisms of sulfur incorporation and isotope fractionation during early diagenesis in sediments of the gulf of California. Marine Chemistry 9, 95-143.

Goldhaber, M.B., Reynolds, R.L., Rye, R.O., 1978. Origin of a South Texas roll-type uranium deposit; II, Sulfide petrology and sulfur isotope studies. Economic Geology 73, 1690-1705.

Gromet, L.P., Haskin, L.A., Korotev, R.L., Dymek, R.F., 1984. The “North American shale composite": Its compilation, major and trace element characteristics. Geochimica et Cosmochimica Acta 48, 2469-2482.

Habicht, K.S., Canfield, D.E., 2001. Isotope fractionation by sulfate-reducing natural populations and the isotopic composition of sulfide in marine sediments. Geology 29, 555-558. 
Harrison, A.G., Thode, H.G., 1958. Mechanism of the bacterial reduction of sulfate from isotopic fractionation studies. Trans. Faraday Soc. 54, 84-92.

Hatch, J.R., Leventhal, J.S., 1992. Relationship between inferred redox potential of the depositional environment and geochemistry of the Upper Pennsylvanian (Missourian) stark shale member of the Dennis Limestone, Wabaunsee County, Kansas, USA. Chemical Geology 99, 65-82.

Holland, H.D., 1979. Metals in black shales; a reassessment. Economic Geology 74, 1676-1680.

Horsfield, B., Bharati, S., Larter, S.R., Leistner, F., Littke, R., Schenk, H.J., Dypvik, H., 1992. On the Atypical Petroleum-Generating Characteristics of Alginite in the Cambrian Alum Shale, in: Schidlowski, M., Golubic, S., Kimberley, M., McKirdy, D., Sr., Trudinger, P.A. (Eds.), Early Organic Evolution. Springer Berlin Heidelberg, pp. 257-266.

Huigen, Y., Andriessen, P., 2004. Thermal effects of Caledonian foreland basin formation, based on fission track analyses applied on basement rocks in central Sweden. Physics and Chemistry of the Earth 29, 683-694.

Israelson, C., Halliday, A.N., Buchardt, B., 1996. U-Pb dating of calcite concretions from Cambrian black shales and the Phanerozoic time scale. Earth and Planetary Science Letters 141, 153-159.

Jones, B., Manning, D.A.C., 1994. Comparison of geochemical indices used for the interpretation of palaeoredox conditions in ancient mudstones. Chemical Geology 111, 111-129.

Jørgensen, B.B., 1979. A theoretical model of the stable sulfur isotope distribution in 
marine sediments. Geochimica et Cosmochimica Acta 43, 363-374.

Jørgensen, B.B., Böttcher, M.E., Lüschen, H., Neretin, L.N., Volkov, I.I., 2004. Anaerobic methane oxidation and a deep H2S sink generate isotopically heavy sulfides in Black Sea sediments. Geochimica et Cosmochimica Acta 68, 2095-2118.

Jørgensen, B.B., Isaksen, M.F., Jannasch, H.W., 1992. Bacterial sulfate reduction above $100^{\circ} \mathrm{C}$ in deep-sea hydrothermal vent sediments. Science $258,1756-1757$.

Kaplan, I.R., Rittenberg, S.C., 1964. Microbiological Fractionation of Sulphur Isotopes. J Gen Microbiol 34, 195-212.

Kisch, H.J., 1980. Incipient metamorphism of Cambro-Silurian clastic rocks from the Jämtland Supergroup, Central Scandinavian Caledonides, Western Sweden: Illite crystallinity and "vitrinite" reflectance. Journal of the Geological Society $137,271-288$.

Lahfid, A., Beyssac, O., Deville, E., Negro, F., Chopin, C., Goffé, B., 2010. Evolution of the Raman spectrum of carbonaceous material in low-grade metasediments of the Glarus Alps (Switzerland). Terra Nova 22, 354-360.

Langford, F.F., Blanc-Valleron, M.M., 1990. Interpreting Rock-Eval pyrolysis data using graphs of pyrolyzable hydrocarbons vs. total organic carbon. AAPG Bulletin 74, 799-804.

Larson, S.A., Tullborg, E.L., Cederbom, C., Stiberg, J.P., Björklund, P.P., Björklund, L., 1999. The Caledonian foreland basin in Scandinavia: Constrained by the thermal maturation of the alum shale. A discussion. GFF 121, 155-156.

Larson, S.A., Tullborg, E.L., Stiberg, J.P., Cederbom, C., 1998. Phanerozoic 
sedimentation and erosion in Sweden and Finland - New results from fission track analyses, in: 23 Nordiske Geologiske Vintermøde.

Lecomte, A., Cathelineau, M., Deloule, E., Brouand, M., Peiffert, C., LoukolaRuskeeniemi, K., Pohjolainen, E., Lahtinen, H., 2014. Uraniferous bitumen nodules in the Talvivaara Ni-Zn-Cu-Co deposit (Finland): influence of metamorphism on uranium mineralization in black shales. Mineralium Deposita 49, 513-533.

Lecomte, A., Cathelineau, M., Michels, R., Brouand, M., 2013. Uranium mineralization in the Alum Shale Formation (Sweden), in: Jonsson, E. (Ed.), 12th Biennial SGA Meeting - Mineral Deposit Research for a High-Tech World. pp. 1654-1656.

Leisen, M., 2011. Analyse chimique des inclusions fluides par ablation-laser couplée à l’ICP-MS et applications géochimiques. Nancy-Université,.

Leventhal, J.S., 1995. Carbon-sulfur plots to show diagenetic and epigenetic sulfidation in sediments. Geochimica et Cosmochimica Acta 59, 1207-1211.

Lewis, S., Henderson, R., Dickens, G., Shields, G., Coxhell, S., 2010. The geochemistry of primary and weathered oil shale and coquina across the Julia Creek vanadium deposit (Queensland, Australia). Mineralium Deposita 45, 599_ 620.

Lippmaa, E., Maremäe, E., Pihlak, A.T., 2011. Resources, production and processing of baltoscandian multimetal black shales. Oil Shale 28, 68-77.

Lyons, T.W., Berner, R.A., 1992. Carbon- sulfur- iron systematics of the uppermost deep-water sediments of the Black Sea. Chemical Geology 99, 1-27. 
Machel, H.G., 2001. Bacterial and thermochemical sulfate reduction in diagenetic settings -- old and new insights. Sedimentary Geology 140, 143-175.

Middleton, M.F., Tullborg, E.L., Larson, S.A., Björklund, L., 1996. Modelling of a Caledonian foreland basin in Sweden: Petrophysical constraints. Marine and Petroleum Geology 13, 407-413.

Montel, F., 1993. Phase equilibria needs for petroleum exploration and production industry. Fluid Phase Equilibria 84, 343-367.

Nemanich, R.J., Solin, S.A., 1979. First- and second-order Raman scattering from finite-size crystals of graphite. Physical Review B 20, 392-401.

Nielsen, A.T., Schovsbo, N.H., 2006. Cambrian to basal Ordovician lithostratigraphy in southern Scandinavia. Bulletin of the Geological Society of Denmark 53, 47-92.

Nielsen, A.T., Schovsbo, N.H., 2011. The Lower Cambrian of Scandinavia: Depositional environment, sequence stratigraphy and palaeogeography. Earth-Science Reviews 107, 207-310.

Nielsen, A.T., Schovsbo, N.H., 2015. The regressive Early-Mid Cambrian “Hawke Bay Event" in Baltoscandia: Epeirogenic uplift in concert with eustasy. Earth-Science Reviews 151, 288-350.

Parnell, J., 1984. The distribution of uranium in kolm: Evidence from backscattered electron imagery. Geologiska Föreningen i Stockholm Förhandlingar 106, 231-234.

Pearce, N.J.G., Perkins, W.T., Westgate, J.A., Gorton, M.P., Jackson, S.E., Neal, C.R., Chenery, S.P., 1997. A compilation of new and published major and trace 
element data for NIST SRM 610 and NIST SRM 612 glass reference materials. Geostandards Newsletter-the Journal of Geostandards and Geoanalysis 21, 115-144.

Petersen, H.I., Schovsbo, N.H., Nielsen, A.T., 2013. Reflectance measurements of zooclasts and solid bitumen in Lower Paleozoic shales, southern Scandinavia: Correlation to vitrinite reflectance. International Journal of Coal Geology 114, 1-18.

Pironon, J., Canals, M., Dubessy, J., Walgenwitz, F., Laplace-Builhe, C., 1998. Volumetric reconstruction of individual oil inclusions by confocal scanning laser microscopy. European Journal of Mineralogy 10, 1143-1150.

Pironon, J., Thiery, R., Ayt Ougougdal, M., Teinturier, S., Beaudoin, G., Walgenwitz, F., 2001. FT-IR measurements of petroleum fluid inclusions: methane, nalkanes and carbon dioxide quantitative analysis. Geofluids 1, 2-10.

Raiswell, R., Berner, R.A., 1985. Pyrite formation in euxinic and semi-euxinic sediments. American Journal of Science 285, 710-724.

Reynard, B., Lécuyer, C., Grandjean, P., 1999. Crystal-chemical controls on rare-earth element concentrations in fossil biogenic apatites and implications for paleoenvironmental reconstructions. Chemical Geology 155, 233-241.

Rodrigues, N., Cobbold, P.R., Loseth, H., Ruffet, G., 2009. Widespread beddingparallel veins of fibrous calcite ('beef') in a mature source rock (Vaca Muerta Fm, Neuquén Basin, Argentina): evidence for overpressure and horizontal compression. Journal of the Geological Society 166, 695-709.

Rudnicki, M.D., Elderfield, H., Spiro, B., 2001. Fractionation of sulfur isotopes during 
bacterial sulfate reduction in deep ocean sidements at elevated temperatures. Geochimica et Cosmochimica Acta 65, 777-789.

Samuelsson, J., Middleton, M.F., 1999. The Caledonian foreland basin in Scandinavia: Constrained by the thermal maturation of the Alum Shale. A reply. GFF $121,157-159$.

Samuelsson, J., Middleton, M.F., 1998. The Caledonian foreland basin in Scandinavia: Constrained by the thermal maturation of the Alum Shale. GFF 120, 307314.

Schovsbo, N.H., 2002. Uranium enrichment shorewards in black shales: A case study from the Scandinavian Alum Shale. GFF 124, 107-115.

Schovsbo, N.H., Nielsen, A.T., Klitten, K., Mathiesen, A., Rasmussen, P., 2011. Shale gas investigations in Denmark: Lower Palaeozoic shales on Bornholm. Geological Survey of Denmark \& Greenland Bulletin 23, 09-12.

Scotese, C.R., McKerrow, W.S., 1990. Revised World maps and introduction. Geological Society, London, Memoirs 12, 1-21.

Strauss, H., 1997. The isotopic composition of sedimentary sulfur through time. Palaeogeography, Palaeoclimatology, Palaeoecology 132, 97-118.

Sundblad, K., Gee, D.G., 1984. Occurrence of a uraniferous-vanadiniferous graphitic phyllite in the Köli Nappes of the Stekenjokk area, central Swedish Caledonides. Geologiska Föreningen i Stockholm Förhandlingar 106, 269_ 274.

Thickpenny, A., 1984. The sedimentology of the Swedish Alum Shales. Geological Society, London, Special Publications 15, 511-525. 
Thiéry, R., Pironon, J., Walgenwitz, F., Montel, F., 2000. PIT (Petroleum Inclusion Thermodynamic): a new modeling tool for the characterization of hydrocarbon fluid inclusions from volumetric and microthermometric measurements. Journal of Geochemical Exploration 69-70, 701-704.

Tissot, B.P., Welte, D.H., 1984. Petroleum Formation and Occurence. Springer Verlag. Tuinstra, F., Koenig, J.L., 1970. Raman Spectrum of Graphite. The Journal of Chemical Physics 53, 1126-1130.

Tullborg, E.-L., Larson, S.A., Stiberg, J.-P., 1996. Subsidence and uplift of the present land surface in the southeastern part of the Fennoscandian Shield. GFF 118, $126-128$.

Turekian, K.K., Wedepohl, K.H., 1961. Distribution of the Elements in Some Major Units of the Earth's Crust. Geological Society of America Bulletin 72, 175192.

Vine, J.D., Tourtelot, E.B., 1970. Geochemistry of black shale deposits; a summary report. Economic Geology 65, 253-272.

Wang, F., 2000. Reflectance of vitrinite-like maceral derived from benthic multicellular algae as organic maturity indicator for pre-Silurian marine strata, in: AAPG International Conference and Exhibition.

Wignall, P.B., 1994. Black shales, Oxford science publications. Clarendon PressOxford University Press, Oxford-New York.

Wilkin, R.T., Arthur, M.A., 2001. Variations in pyrite texture, sulfur isotope composition, and iron systematics in the Black Sea: evidence for Late Pleistocene to Holocene excursions of the $\mathrm{O}_{2}-\mathrm{H}_{2} \mathrm{~S}$ redox transition. 
Geochimica et Cosmochimica Acta 65, 1399-1416.

Yu, B., Dong, H., Widom, E., Chen, J., Lin, C., 2009. Geochemistry of basal Cambrian black shales and cherts from the Northern Tarim Basin, Northwest China: Implications for depositional setting and tectonic history. Journal of Asian Earth Sciences 34, 418-436.

Zhang, Y.-G., Frantz, J.D., 1987. Determination of the homogenization temperatures and densities of supercritical fluids in the system $\mathrm{NaCl}-\mathrm{KCl}-\mathrm{CaCl}_{2}-\mathrm{H}_{2} \mathrm{O}$ using synthetic fluid inclusions. Chemical Geology 64, 335-350.

Ziegler, P.A., 1988. Evolution of the Arctic-North Atlantic and the Western Tethys. American Association of Petroleum Geologists, Tulsa, Okla., U.S.A. 


\section{Table caption}

Table 1 List of samples with corresponding wells and depths

Table 2 Selected metals, carbon, sulfur and phosphorus whole rock concentrations in several Alum Shale samples (Total Organic Carbon TOC, Total Sulfur TS and Total Phosphorus TP are in wt.\%. Other elements are in ppm)

Table 3 Rock Eval analyses on several Alum Shale samples. S1 and S2 are in mg HC/g Rock, $\mathrm{S} 3$ in $\mathrm{mg} \mathrm{CO}_{2} / \mathrm{g}$ Rock, $\mathrm{T}_{\max }$ in ${ }^{\circ} \mathrm{C}$, TOC in wt. $\%, \mathrm{HI}$ in $\mathrm{mg} \mathrm{HC} / \mathrm{g}$ TOC and OI $\mathrm{mg} \mathrm{CO} / \mathrm{g}$ TOC

Table $4 \delta^{34} S$ values (in \%o) for different pyrite generations in the Alum Shale Formation

Table 5 Uranium and Rare Earth Element concentrations in apatite- $(\mathrm{CaF}[\mathrm{OH}])$ nodules (ppm) from LA-ICP-MS analysis

Table 6 Main features of selected hydrocarbon-bearing inclusions in concretions and fractures. Homogenization temperatures $\mathrm{Th}$ are in ${ }^{\circ} \mathrm{C}$, vapor volume fractions $\mathrm{Fv}$ in $\%, \mathrm{CH} 4, \mathrm{CO} 2$ and alkane content in $\mathrm{mol} / \mathrm{kg}$

Table 7 Peak area and calculated temperatures for Raman spectra on carbonaceous nodules. RA1 and RA2 are two area ratios used to estimate temperature. Carbonaceous matter types (CM) are indicated as PB Cal (Pyrobitumen under calcite), PB (Pyrobitumen) and PV (Pseudo-vitrinite)

Table 8Composition of U-Ti bearing minerals in Alum Shale determined by EPMA in weight percents of major oxides 


\section{Figure captions}

Fig. 1 Geological map of the Fennoscandian Shield with main Alum Shale occurrences (modified from Thickpenny, 1984). For a more comprehensive map of Lower Palaeozoic strata in Baltoscandia see Nielsen and Schovsbo, 2015

Fig. 2 a. Metamorphic Alum Shale (Tåsjö) with fractured massive pyrites and calcite in pressure shadows; b. Metamorphic Alum Shale (Tåsjö) with fractured pyrite beds and calcite-pyrobitumen fracture fillings (left); c. Immature Alum Shale (Västergötland)

Fig. 3 X-Ray diffractograms of immature Alum Shale (Närke) and metamorphic Alum Shale (Tåsjö)

Fig. 4 Average concentrations (As, $\mathrm{Co}, \mathrm{Cr}, \mathrm{Cu}, \mathrm{Mo}, \mathrm{Ni}, \mathrm{Pb}, \mathrm{Th}, \mathrm{U}, \mathrm{V}, \mathrm{Zn}$ ) in Alum Shale occurrences analyzed for this study (dots for metamorphic samples from Myrviken, Lövstrand and Tåsjö, squares for non metamorphic samples from Närke, Östergötland, Öland, Skåne, Västergötland), compared with reference shales (Marine shales from Turekian and Wedepohl, 1961; Tarim basin black shales from Yu et al., 2009; Ronneburg black shales from Lippmaa et al., 2011; Ohio shale from Lewis et al., 2010)

Fig. 5 a. Carbon-sulfur plot for the Alum Shale Formation. Oxic marine depositional settings and euxinic (anoxic-sulfidic) water column are indicated. Euxinic but Felimited sediments would plot along a sub-horizontal trend with an extrapolated positive intercept on the S-axis (Raiswell and Berner, 1985; Leventhal, 1995). b. V/(V + Ni) vs. V/Cr crossplot for the Alum Shale Formation. Depositional settings ranges for $\mathrm{V} / \mathrm{Cr}$ and $\mathrm{V} /(\mathrm{V}+\mathrm{Ni}$ ) are from Jones and Manning (1994) and from Hatch and 
Leventhal (1992), respectively

Fig. 6 Uranium-carbon plot (a) and uranium-phosphorus plot (b) for several Alum Shale occurrences. All values are density-corrected. Artificial maturation residues are indicated in Fig. 6a

Fig. 7 Petrographic features of organic matter in the Alum Shale Formation. a. UVFluorescent macerals (liptinite) in immature Alum Shale (Östergötland); b. UVFluorescent macerals (liptinite) in immature Alum Shale (Närke); c. Pseudo-vitrinite in immature Alum Shale (Närke); d. Pyrobitumen in metamorphic Alum Shale (Myrviken); e. Pyrobitumen vein in metamorphic Alum Shale (Tåsjö); f. Pyrobitumen vein (with calcite) in metamorphic Alum Shale (Tåsjö). Bit: pyrobitumen, Cal: calcite, PV: pseudo-vitrinite, Pyr: pyrite, Qtz:quartz

Fig. 8 S2 vs. TOC diagram for immature and metamorphic Alum Shale Fig. 9 IH vs. Tmax diagram for immature and metamorphic Alum Shale Fig. 10 S1 vs. S2 diagram for immature and metamorphic Alum Shale Fig. 11 Petrographic features of sedimentary and diagenetic sulfides. a. Framboids and euhedral pyrites in immature Alum Shale (Östergötland); b. Detailed view of an isolated framboid (Västergötland); c. Beds of (sub)euhedral pyrites underlining sedimentary(Tåsjö); d. Beds of (sub)euhedral pyrites (Tåsjö); e. Massive pyrite with core of coalescent syn-sedimentary pyrites and large pyrite crystals growing perpendicularly (Närke); f. Large isolated pyrite and deformation of sedimentary bedding (Närke); g. Massive pyrites in heterogeneous porous cement (Östergötland); h. Homogeneous pyrite veins and fracture fillings of euhedral pyrites (Östergötland) Fig. $12 \mathrm{As}, \mathrm{Cu}$ and $\mathrm{Ni}$ content in sulfides from immature and metamorphic Alum 
Shale. a. Diagenetic pyrite with no particular enrichment in $\mathrm{As}, \mathrm{Cu}$ and $\mathrm{Ni}$; b. Framboids with high $\mathrm{Cu}$ concentration compared to syngenetic euhedral pyrites; $\mathbf{c}$. Synmetamorphic pyrite overgrowth with Ni enrichment and framboids remnants with high $\mathrm{Cu}$ concentration; d. Massive diagenetic pyrite with no particular enrichment and metamorphic overgrowths with Ni-rich pyrite and chalcopyrite $(\mathrm{Ccp})$

Fig. 13 Histogram of $\delta^{34} S$ values of pyrite in the Alum Shale Formation

Fig. 14 a. Apatite- $(\mathrm{CaF}[\mathrm{OH}])$ nodule surrounded by pyrites in immature Alum Shale (Östergötland); b. Carbonaceous matter veinlet (black) with uranium phosphosilicates (white) and syn-sedimentary pyrites (light grey) in metamorphic Alum Shale (Tåsjö); c. Porous apatite- $(\mathrm{CaF}[\mathrm{OH}])$ nodule surrounded by uranium phosphosilicates clusters (white) in metamorphic Alum Shale (Tåsjö); d. Porous apatite$(\mathrm{CaF}[\mathrm{OH}])$ nodule surrounded by carbonaceous matter and uranium phosphosilicates clusters (white) in metamorphic Alum Shale (Tåsjö); e. Uranium phosphosilicates spherulites inside apatite-(CaF[OH]) nodule (Tåsjö); f. Apatite-(CaF[OH]) anhedral crystals associated with uranium phospho-silicates and carbonaceous matter on the edge of a porous apatite-(CaF[OH]) nodule (Tåsjö). Ap: apatite$(\mathrm{CaF}[\mathrm{OH}]), \mathrm{C}$ : carbonaceous matter, P-cof: uranium phospho-silicates of various composition (see text for details), Py: pyrite. Red circles and green circles correspond to uranium minerals chemical analyses and phosphate nodules LA-ICP/MS analyses, respectively

Fig. 15 REE patterns in apatite-(CaF[OH]) nodules from immature and metamorphic Alum Shale. All spectra are normalized to North American Shale Composite (NASC 
REE concentrations after Gromet et al., 1984) and metamorphic shales values are multiplied by 10 to improve readability

Fig. 16 a. Breccia with angular calcite crystals (Öland); b. Top view of calcite concretion (beef) with centimetric crystals (Västergötland); c. Hydrocarbon-bearing inclusions in calcite (Öland); d. Aqueous inclusion in calcite (Öland); e. UVfluorescent oil inclusions (Västergötland); f. 3-phase (oil-water-gas) inclusion (Öland) Fig. 17 Histograms of homogenization temperatures for fluid inclusions in concretions (a) and fracture fillings in Ordovician limestones (b)

Fig. 18 Evolution of vapor volume fraction with homogenization temperature for various hydrocarbon-bearing inclusions in concretions (blue circles) and fractures (red squares)

Fig. 19 Pressure-Temperature diagrams for inclusions in concretions (a) and fractures (b). Black lines represent isochores and isopleths of petroleum inclusions. Gray bands represent domain of isochores for aqueous inclusions. Dotted line is determined with the mode of homogenization temperatures and the mean salinity of aqueous inclusions. Trapping conditions correspond to intersection of intersection domains in blue for concretions $\left(\mathrm{A}^{\prime}, \mathrm{A}, \mathrm{B}\right)$ and in red for fractures $(\mathrm{C}, \mathrm{D}$, and $\mathrm{E})$

Fig. 20 a. Example of Raman spectra obtained on carbonaceous matter in Alum Shale; b. Peak fitting on first order region of Raman spectra using Lorentzian profiles. Complete dataset in table 3

Fig. 21 Sulfide modifications in metamorphic Alum Shale. a. Cataclased massive pyrite (Myrviken); b. Fractured massive pyrite with pyrite overgrowths and late calcite fillings (Tåsjö); c. Folded bed of framboids and (sub)euhedral pyrites (Tåsjö); 
d. Interpenetrative boundaries on euhedral pyrites (Tåsjö); e. Framboids in synmetamorphic pyrite overgrowths (Myrviken); f. Fractures in pyrites filled with chalcopyrite and sphalerite (Myrviken); g. Massive pyrite with chalcopyrite and sphalerite inclusions (Myrviken); h. Pyrite-chalcopyrite-sphalerite paragenesis (Myrviken). Ccp: chalcopyrite, Pyr: pyrite, Sph: sphalerite

Fig. 22 a. Brannerite (white) in syn-metamorphic pyrites (Myrviken); b. Uraninite (white dots) in syn-metamorphic pyrites surrounded by barite (Tåsjö); c. Uranium phospho-silicates in metamorphic Alum Shale (Myrviken); d. Altered uraninite core (white) rimmed by uranium phospho-silicates (Tåsjö); e. Pyrite rimmed by U-Ti phospho-silicates (Tåsjö); f. Brannerite rimmed by U-Ti phospho-silicates (Tåsjö). Brn: brannerite, Brt: barite, Gn: galena, P-cof: uranium phospho-silicates of various composition (see text for details), Py: pyrite, Urn: uraninite. Red circles correspond to uranium mineral chemical analyses

Fig. 23 Ti-Si (a), U-P (b), U+Ca+Y-Si+P (c) and Ca+Y+P-U+Si (d) diagrams for U-Ti-Y minerals in Alum Shale (APFU Atoms Per Formula Unit). Theorical uraninite, (P)coffinite, brannerite and xenotime are indicated by large black dots. Circles represent Y-poor/Ti-rich minerals (Brannerite group), squares represent Y-poor/Tipoor minerals (Uraninite group) and diamonds represent Y-rich/Ti-poor minerals (Xenotime group)

Fig. 24 Evolution of $\delta^{34} S$ values in pyrites from sedimentation to metamorphism. Pyrite generations are indicated as Py1 to Py6 in the figure and described in the text Fig. 25 Uranium-phosphorus plot for the Alum Shale Formation for whole rock (same data as Fig. 6b) and discrete uranium concentrations in phosphate nodules 
(frequency of occurrence histogram on the right). The shaded line illustrates the extrapolation at $60 \mathrm{mg} \cdot \mathrm{cm}^{-3}$ of phosphorus (average phosphorus content in apatite$(\mathrm{CaF}[\mathrm{OH}])$

Fig. 26 Pressure-Temperature diagram with trapping condition of fluid inclusions and possible evolution pathways: 1) low geothermal gradient pathway $\left(<20^{\circ} \mathrm{C} / \mathrm{km}\right)$; 2) $20-30^{\circ} \mathrm{C} / \mathrm{km}$ geothermal pathway; 3) low burial

Fig. 27 Schematic scenario proposed to describe the evolution of organic matter, sulfides and uranium in the Alum Shale Formation, from sedimentation to Greenschist metamorphism 


\begin{tabular}{|c|c|c|c|}
\hline Sample & Location & Core & Depth (m) \\
\hline Myr-7 & Myrviken & Harå 78001 & 106.80 \\
\hline Myr-9 & Myrviken & Harå 78001 & 108.75 \\
\hline Myr-16 & Myrviken & Harå 78001 & 135.10 \\
\hline Myr-24 & Myrviken & Myrviken 78002 & 57.70 \\
\hline Lovst-1 & Lövstrand & ВH593 & 158.60 \\
\hline Tasjo-2 & Tåsjö & KRODD 06016 & 23.60 \\
\hline Tasjo-4 & Tåsjö & KRODD 06017 & 11.25 \\
\hline Tasjo-5 & Tåsjö & KRODD 06017 & 14.60 \\
\hline Tasjo-7 & Tåsjö & KRODD 06017 & 16.80 \\
\hline Tasjo-8 & Tåsjö & KRODD 06017 & 17.20 \\
\hline Tasjo-9 & Tåsjö & KRODD 06017 & 17.80 \\
\hline Tasjo-10 & Tåsjö & KRODD 06017 & 19.00 \\
\hline Tasjo-11 & Tåsjö & KRODD 06017 & 20.00 \\
\hline Tasjo-12 & Tåsjö & KRODD 06017 & 21.10 \\
\hline Tasjo-13 & Tåsjö & KRODD 06017 & 21.35 \\
\hline Tasjo-27 & Tåsjö & KRODD 07025 & 101.35 \\
\hline Tasjo-36 & Tåsjö & KRODD 07025 & 126.45 \\
\hline Narke-5 & Närke & Åkerby 65-59 & 21.10 \\
\hline Narke-9 & Närke & Anstorp-1 & 22.00 \\
\hline Narke-13 & Närke & Anstorp-1 & 27.75 \\
\hline Narke-16 & Närke & Norrtorp & 16.70 \\
\hline Narke-20 & Närke & Åkerby 62-58 & 12.15 \\
\hline Ogot-1 & Östergötland & Bårstad 85001 & 19.50 \\
\hline Ogot-8 & Östergötland & Bårstad 85001 & 35.50 \\
\hline Ogot-9 & Östergötland & Bårstad 85001 & 35.80 \\
\hline Ogot-13 & Östergötland & Bårstad 85001 & 24-25 (composite) \\
\hline Oland-3 & Öland & Skärlöv & 24.50 \\
\hline Oland-10 & Öland & Skärlöv & 37-39 (composite) \\
\hline Skane-4 & Skåne & Killeröd & 32.50 \\
\hline Skane-7 & Skåne & Killeröd & 86.64 \\
\hline Skane-17 & Skåne & Tosterup-1 & 60.38 \\
\hline Skane-19 & Skåne & Tosterup-1 & 64.46 \\
\hline Skane-21 & Skåne & Tosterup-1 & 66.30 \\
\hline Skane-27 & Skåne & Tosterup-1 & 82.90 \\
\hline Vgot-1 & Västergötland & Botorp-1 & 17.90 \\
\hline Vgot-3 & Västergötland & Botorp-1 & 19.00 \\
\hline Vgot-4 & Västergötland & Botorp-1 & 20.00 \\
\hline Vgot-6 & Västergötland & Botorp-1 & 24.23 \\
\hline Vgot-12 & Västergötland & Luttorp-1 & 32.30 \\
\hline Vgot-14 & Västergötland & Luttorp-1 & 33.49 \\
\hline Vgot-16 & Västergötland & Öglunda & 28.90 \\
\hline Vgot-18 & Västergötland & Öglunda & 31.60 \\
\hline Vgot-27 & Västergötland & Profil 5 & 9.30 \\
\hline
\end{tabular}

Table 1 List of samples with corresponding wells and depths 


\begin{tabular}{|c|c|c|c|c|c|c|c|c|c|c|c|c|c|c|c|}
\hline Location & Sample & $\begin{array}{c}\text { TOC } \\
w t . \%\end{array}$ & $\begin{array}{c}T S \\
w t . \%\end{array}$ & $\begin{array}{c}T P \\
w t . \%\end{array}$ & $\begin{array}{c}\text { As } \\
p p m\end{array}$ & $\begin{array}{c}\text { Co } \\
p p m\end{array}$ & $\begin{array}{c}C r \\
p p m\end{array}$ & $\begin{array}{c}C u \\
p p m\end{array}$ & $\begin{array}{c}\text { Mo } \\
\text { ppm }\end{array}$ & $\begin{array}{c}N i \\
p p m\end{array}$ & $\begin{array}{c}P b \\
p p m\end{array}$ & $\begin{array}{c}\text { Th } \\
p p m\end{array}$ & $\begin{array}{c}U \\
\text { ppm }\end{array}$ & $\begin{array}{c}V \\
p p m\end{array}$ & $\begin{array}{c}\mathrm{Zn} \\
p p m\end{array}$ \\
\hline Myrviken & Myr-9 & 13.1 & 4.8 & 4.4 & 101.9 & 26.4 & 84.0 & 157.9 & 396.5 & 357.1 & 62.6 & 12.5 & 212.3 & 1328.0 & 272.3 \\
\hline Lövstrand & Lovst-1 & 4.8 & 4.6 & 7.9 & 74.4 & 22.6 & 68.6 & 103.2 & 134.2 & 137.6 & 119.4 & 11.3 & 89.4 & 425.7 & 51.6 \\
\hline Tåsjö & Tasjo-8 & 10.1 & 4.9 & 6.3 & 74.6 & 25.0 & 86.1 & 117.4 & 210.9 & 207.9 & 32.8 & 13.6 & 149.8 & 441.2 & 123.0 \\
\hline Tåsjö & Tasjo-9 & 10.2 & 5.0 & 5.0 & 74.2 & 27.2 & 98.0 & 173.9 & 173.1 & 258.2 & 36.9 & 14.4 & 118.9 & 1464.0 & 140.0 \\
\hline Tåsjö & Tasjo-10 & 11.3 & 5.2 & 6.3 & 80.2 & 26.2 & 91.2 & 126.4 & 223.0 & 218.1 & 33.7 & 14.4 & 146.8 & 458.3 & 127.9 \\
\hline Tåsjö & Tasjo-11 & 11.8 & 5.0 & 5.7 & 69.9 & 26.4 & 83.2 & 215.4 & 240.9 & 215.3 & 42.3 & 14.3 & 185.4 & 773.0 & 129.7 \\
\hline Tåsjö & Tasjo-12 & 12.2 & 5.8 & 6.3 & 73.5 & 24.7 & 79.7 & 148.6 & 198.3 & 175.7 & 34.8 & 13.4 & 141.2 & 792.5 & 139.7 \\
\hline Tåsjö & Tasjo-13 & 11.0 & 5.6 & 6.6 & 90.0 & 28.6 & 87.5 & 163.8 & 226.2 & 243.9 & 38.6 & 14.4 & 175.1 & 709.6 & 150.0 \\
\hline Närke & Narke-5 & 18.5 & 5.2 & 5.9 & 65.4 & 24.9 & 90.3 & 192.6 & 113.2 & 117.9 & 57.0 & 11.7 & 124.5 & 450.6 & 56.9 \\
\hline Närke & Narke-9 & 19.6 & 6.2 & 5.5 & 85.4 & 30.6 & 59.6 & 178.7 & 160.3 & 196.0 & 31.6 & 11.1 & 120.9 & 510.2 & 90.2 \\
\hline Närke & Narke-13 & 15.5 & 5.7 & 3.3 & 77.0 & 29.9 & 69.2 & 224.0 & 134.7 & 108.5 & 139.2 & 11.9 & 89.1 & 396.4 & 39.9 \\
\hline Närke & Narke-20 & 18.9 & 6.2 & 6.3 & 69.6 & 24.1 & 93.5 & 145.9 & 106.5 & 111.5 & 63.3 & 11.9 & 134.9 & 408.9 & < L.D. \\
\hline Östergötland & Ogot-1 & 16.4 & 6.1 & 3.5 & 59.3 & 18.8 & 75.3 & 214.9 & 156.8 & 290.9 & 46.7 & 12.2 & 116.9 & 1406.0 & 147.9 \\
\hline Östergötland & Ogot-13 & 14.1 & 8.4 & 3.7 & 165.7 & 46.3 & 87.7 & 195.5 & 205.5 & 403.7 & 33.0 & 12.6 & 100.4 & 1298.0 & 69.1 \\
\hline Öland & Oland-10 & 9.2 & 10.4 & 3.5 & 212.0 & 42.5 & 71.2 & 168.9 & 115.3 & 95.7 & 24.6 & 11.5 & 47.1 & 303.6 & 132.3 \\
\hline Skåne & Skane-7 & 5.5 & 5.3 & 2.2 & 64.2 & 27.0 & 76.5 & 147.1 & 104.1 & 129.4 & 27.7 & 12.7 & 30.6 & 420.0 & 38.7 \\
\hline Skåne & Skane-21 & 9.8 & 6.2 & 3.3 & 96.1 & 33.1 & 72.3 & 148.8 & 114.5 & 338.1 & 31.1 & 11.3 & 92.1 & 1318.0 & 1190.0 \\
\hline Västergötland & Vgot-3 & 10.3 & 6.2 & 3.3 & 97.9 & 29.3 & 61.6 & 168.2 & 221.8 & 180.7 & 93.6 & 10.1 & 78.1 & 622.3 & 36.4 \\
\hline Västergötland & Vgot-4 & 13.3 & 6.3 & 3.7 & 89.3 & 27.4 & 65.2 & 166.6 & 258.0 & 176.4 & 34.2 & 11.5 & 170.1 & 592.7 & 64.5 \\
\hline Västergötland & Vgot-14 & 8.1 & 8.7 & 3.3 & 110.8 & 37.7 & 72.8 & 162.7 & 119.1 & 113.4 & 25.9 & 12.4 & 36.7 & 378.3 & 59.1 \\
\hline Västergötland & Vgot-16 & 10.2 & 6.3 & 3.9 & 99.0 & 30.4 & 62.5 & 171.8 & 231.8 & 168.5 & 28.8 & 11.3 & 111.9 & 572.4 & 282.2 \\
\hline
\end{tabular}

Table 2 Selected metals, carbon, sulfur and phosphorus whole rock concentrations in several Alum Shale samples (Total Organic Carbon TOC, Total Sulfur TS and Total Phosphorus TP are in wt.\%. Other elements are in ppm) 


\begin{tabular}{|c|c|c|c|c|c|c|c|c|}
\hline Location & Sample & $\begin{array}{c}S 1 \\
m g \text { HC/g Rock }\end{array}$ & $\begin{array}{c}S 2 \\
m g \text { HC/g Rock }\end{array}$ & $\begin{array}{c}S 3 \\
m g \mathrm{CO}_{2} / \mathrm{g} \text { Rock }\end{array}$ & $\begin{array}{c}\operatorname{Tmax} \\
{ }^{\circ} \mathrm{C}\end{array}$ & $\begin{array}{c}\text { TOC } \\
w t . \%\end{array}$ & $\begin{array}{c}H I \\
m g H C / g \text { TOC }\end{array}$ & $\begin{array}{c}\mathrm{OI} \\
\mathrm{mg} \mathrm{CO} / \mathrm{g} \text { TOC }\end{array}$ \\
\hline Myrviken & Myr-9 & 0.24 & 1.09 & 0.52 & 427 & 12.50 & 9 & 4 \\
\hline Lövstrand & Lovst-1 & 0.06 & 0.21 & 1.00 & 398 & 5.65 & 4 & 18 \\
\hline Tåsjö & Tasjo-8 & 0.27 & 0.72 & 1.12 & 442 & 10.58 & 7 & 11 \\
\hline Tåsjö & Tasjo-9 & 0.16 & 0.52 & 0.86 & 435 & 10.79 & 5 & 8 \\
\hline Tåsjö & Tasjo-10 & 0.16 & 0.72 & 0.74 & 439 & 11.79 & 6 & 6 \\
\hline Tåsjö & Tasjo-11 & 0.19 & 0.99 & 0.75 & 441 & 12.77 & 8 & 6 \\
\hline Tåsjö & Tasjo-12 & 0.21 & 0.72 & 0.69 & 441 & 12.79 & 6 & 5 \\
\hline Tåsjö & Tasjo-13 & 0.12 & 0.65 & 0.76 & 426 & 11.53 & 6 & 7 \\
\hline Närke & Narke-5 & 1.71 & 98.61 & 1.07 & 418 & 18.96 & 520 & 6 \\
\hline Närke & Narke-9 & 1.33 & 98.16 & 1.05 & 415 & 19.23 & 510 & 5 \\
\hline Närke & Narke-13 & 1.62 & 86.75 & 0.93 & 419 & 16.09 & 539 & 6 \\
\hline Närke & Narke-16 & 0.45 & 30.04 & 1.00 & 414 & 6.38 & 471 & 16 \\
\hline Närke & Narke-20 & 1.48 & 99.94 & 0.86 & 416 & 18.95 & 527 & 5 \\
\hline Östergötland & Ogot-1 & 1.28 & 90.25 & 1.27 & 417 & 17.12 & 527 & 7 \\
\hline Östergötland & Ogot-13 & 0.87 & 77.30 & 0.45 & 417 & 14.21 & 544 & 3 \\
\hline Öland & Oland-10 & 0.56 & 32.03 & 0.31 & 426 & 8.18 & 392 & 4 \\
\hline Skåne & Skane-4 & 0.08 & 0.28 & 0.87 & 451 & 5.49 & 5 & 16 \\
\hline Skåne & Skane-7 & 0.03 & 0.11 & 0.40 & 425 & 5.48 & 2 & 7 \\
\hline Skåne & Skane-21 & 0.17 & 0.77 & 0.41 & 435 & 10.20 & 8 & 4 \\
\hline Västergötland & Vgot-3 & 0.76 & 13.00 & 0.44 & 406 & 9.83 & 132 & 5 \\
\hline Västergötland & Vgot-4 & 0.47 & 19.76 & 0.86 & 418 & 13.71 & 144 & 6 \\
\hline Västergötland & Vgot-14 & 1.45 & 22.95 & 0.16 & 425 & 7.80 & 294 & 2 \\
\hline Västergötland & Vgot-16 & 0.51 & 19.41 & 0.92 & 409 & 10.45 & 186 & 9 \\
\hline Västergötland & Vgot-18 & 0.63 & 31.13 & 0.88 & 416 & 13.54 & 230 & 7 \\
\hline
\end{tabular}

Table 3 Rock Eval analyses on several Alum Shale samples. S1 and S2 are in mg HC/g Rock, S3 in mg CO2/g Rock, Tmax in ${ }^{\circ} \mathrm{C}$, TOC in wt. \%, $\mathrm{HI}$ in mg $\mathrm{HC} / \mathrm{g}$ TOC and OI mg CO2/g TOC 


\begin{tabular}{|c|c|c|c|c|c|c|c|}
\hline Location & Analysis & $\begin{array}{c}\text { Pyrite } \\
\text { generation }\end{array}$ & $\begin{array}{c}\delta^{34} S \\
\% 0\end{array}$ & Location & Analysis & $\begin{array}{c}\text { Pyrite } \\
\text { generation }\end{array}$ & $\begin{array}{c}\delta^{34} S \\
\% 0\end{array}$ \\
\hline \multirow{6}{*}{ Tåsjö } & Bjo20_1@131 & Py3 & 24.2076 & \multirow{24}{*}{ Östergötland } & OG9_2@151 & Py3 & 21.6736 \\
\hline & Bjo20_1@132 & Py6 & 15.3526 & & OG9_2@152 & Py3 & 22.5776 \\
\hline & Bjo20_1@133 & Рy3 & 24.5686 & & OG83_1@41 & Py3 & 15.9208 \\
\hline & Bjo20_1@134 & Py6 & 12.6136 & & OG83_1@42 & Py3 & 15.9448 \\
\hline & Bjo20_2@135 & Py1 & 29.4566 & & OG83_1@43 & Py3 & 32.7708 \\
\hline & Bjo20_2@136 & Py2 & 25.5676 & & OG83_1@44 & Py3 & 23.1518 \\
\hline \multirow{9}{*}{ Myrviken } & Myr7_1@137 & Py2 & 23.6546 & & OG83_1@45 & Py3 & 21.7538 \\
\hline & Myr7_1@138 & Py2 & 23.9986 & & OG83_1@46 & Py4 & 30.3348 \\
\hline & Myr7_2@139 & Py3 & 24.0196 & & OG83_1@47 & Py4 & 30.0598 \\
\hline & Myr7_2@140 & Py6 & 10.2766 & & OG83_1@48 & Py4 & 30.4058 \\
\hline & Myr7_2@141 & Py6 & 8.9886 & & OG83_2@49 & Py5 & 21.6778 \\
\hline & Myr7_3@142 & Py3 & 22.2956 & & OG83_2@50 & Py5 & 20.1278 \\
\hline & Myr7_3@143 & Py6 & 8.4416 & & OG83_2@51 & Py5 & 20.5618 \\
\hline & Myr7_3@144 & Py6 & 9.5676 & & OG83_2@52 & Py 4 & 29.4698 \\
\hline & Myr7_3@145 & Py3 & 22.4846 & & OG83_3@53 & Py3 & 16.3168 \\
\hline \multirow{19}{*}{ Östergötland } & OG82_1@63 & Py5 & 20.2198 & & OG83_3@54 & Py 4 & 30.3068 \\
\hline & OG82_1@64 & Py3 & 19.4318 & & OG83_3@55 & Py5 & 19.0468 \\
\hline & OG82_1@65 & Py3 & 19.2828 & & OG83_3@56 & Py 4 & 30.6878 \\
\hline & OG82_1@66 & Py3 & 18.4718 & & OG83_3@57 & Py4 & 29.7058 \\
\hline & OG82_1@67 & Py3 & 18.2058 & & OG83_3@58 & Py5 & 23.4248 \\
\hline & OG82_1@68 & Py4 & 31.6618 & & OG83_3@59 & Py5 & 22.2148 \\
\hline & OG82_1@69 & Py 4 & 30.9528 & & OG83_3@60 & Py5 & 18.9978 \\
\hline & OG82_2@70 & Py4 & 29.9218 & & OG83_3@61 & Py5 & 22.4458 \\
\hline & OG82_2@71 & Py5 & 19.7738 & & OG83_3@62 & Py5 & 22.4108 \\
\hline & OG82_2@72 & Py4 & 31.0198 & \multirow{10}{*}{ Skåne } & Ska17@122 & Py2 & 24.2826 \\
\hline & OG82_2@73 & Py4 & 30.4128 & & Ska17@123 & Py2 & 24.1856 \\
\hline & OG82_3@74 & Py5 & 19.4538 & & Ska17@124 & Py2 & 24.4376 \\
\hline & OG82_3@75 & Py4 & 30.5718 & & Ska17@125 & Py2 & 22.6776 \\
\hline & OG82_3@76 & Py4 & 30.7758 & & Ska17@126 & Py2 & 22.7096 \\
\hline & OG9_1@146 & Py1 & 31.8796 & & Ska17@127 & Py2 & 22.0926 \\
\hline & OG9_1@147 & Py1 & 39.1756 & & Ska17@128 & Py2 & 24.7906 \\
\hline & OG9_1@148 & Py1 & 39.5386 & & Ska17@129 & Py2 & 24.4456 \\
\hline & OG9_1@149 & Py1 & 35.9376 & & Ska17@130 & Py2 & 24.5816 \\
\hline & OG9_1@150 & Py1 & -4.9634 & & & & \\
\hline
\end{tabular}

Table 4: $\delta 34$ S values (in \%o) for different pyrite generations in the Alum Shale Formation 


\begin{tabular}{|c|c|c|c|c|c|c|c|c|c|c|c|c|c|c|c|c|c|}
\hline Location & Sample & Point & $\begin{array}{c}U \\
p p m\end{array}$ & $\begin{array}{c}L a \\
p p m \\
\end{array}$ & $\begin{array}{c}C e \\
p p m\end{array}$ & $\begin{array}{c}P r \\
p p m\end{array}$ & $\begin{array}{c}N d \\
p p m \\
\end{array}$ & $\begin{array}{c}S m \\
p p m\end{array}$ & $\begin{array}{c}E u \\
p p m \\
\end{array}$ & $\begin{array}{c}G d \\
p p m\end{array}$ & $\begin{array}{c}T b \\
p p m \\
\end{array}$ & $\begin{array}{c}D y \\
p p m\end{array}$ & $\begin{array}{c}\text { Ho } \\
\text { ppm }\end{array}$ & $\begin{array}{c}E r \\
p p m \\
\end{array}$ & $\begin{array}{c}\text { Tm } \\
\text { ppm }\end{array}$ & $\begin{array}{c}Y b \\
p p m\end{array}$ & $\begin{array}{c}L u \\
p p m\end{array}$ \\
\hline Östergötland & Ogot-8 & 1 & 170 & 264 & 1331 & 268 & 1501 & 381 & 103 & 409 & 59 & 280 & 41 & 84 & 6 & 20 & 3 \\
\hline Östergötland & Ogot-8 & 2 & 152 & 289 & 1454 & 319 & 1735 & 494 & 112 & 454 & 66 & 319 & 51 & 91 & 7 & 28 & 3 \\
\hline Östergötland & Ogot-8 & 3 & 140 & 341 & 1606 & 350 & 1945 & 588 & 124 & 540 & 72 & 357 & 53 & 98 & 8 & 34 & 2 \\
\hline Östergötland & Ogot-8 & 4 & 131 & 229 & 1200 & 242 & 1374 & 384 & 84 & 337 & 49 & 226 & 34 & 71 & 5 & 23 & 3 \\
\hline Östergötland & Ogot- 8 & 5 & 167 & 417 & 2106 & 439 & 2423 & 677 & 155 & 652 & 87 & 436 & 62 & 118 & 10 & 32 & 4 \\
\hline Östergötland & Ogot- 8 & 6 & 161 & 308 & 1464 & 317 & 1770 & 463 & 107 & 436 & 58 & 290 & 42 & 86 & 7 & 25 & 2 \\
\hline Östergötland & Ogot-8 & 7 & 185 & 354 & 1843 & 397 & 2075 & 555 & 127 & 523 & 70 & 334 & 54 & 90 & 8 & 29 & 4 \\
\hline Tåsjö & Tasjo-2 & 8 & 770 & 608 & 1640 & 236 & 1199 & 361 & 94 & 457 & 62 & 335 & 64 & 153 & 15 & 69 & 10 \\
\hline Tåsjö & Tasjo-2 & 9 & 846 & 686 & 1880 & 271 & 1384 & 433 & 113 & 564 & 77 & 406 & 74 & 174 & 18 & 82 & 11 \\
\hline Tåsjö & Tasjo-2 & 10 & 802 & 679 & 1865 & 267 & 1397 & 424 & 113 & 564 & 75 & 424 & 74 & 169 & 16 & 81 & 11 \\
\hline Tåsjö & Tasjo-2 & 11 & 900 & 690 & 1924 & 267 & 1442 & 471 & 112 & 571 & 80 & 436 & 81 & 176 & 18 & 83 & 11 \\
\hline Tåsjö & Tasjo-2 & 12 & 2555 & 984 & 2939 & 423 & 2220 & 625 & 142 & 786 & 106 & 564 & 104 & 247 & 25 & 131 & 17 \\
\hline Tåsjö & Tasjo-2 & 13 & 1955 & 1080 & 3301 & 482 & 2563 & 729 & 158 & 854 & 119 & 648 & 118 & 274 & 29 & 142 & 18 \\
\hline Tåsjö & Tasjo-2 & 14 & 540 & 1047 & 3139 & 463 & 2439 & 714 & 153 & 798 & 108 & 558 & 103 & 239 & 24 & 126 & 17 \\
\hline Tåsjö & Tasjo-2 & 15 & 936 & 1093 & 3231 & 484 & 2473 & 713 & 167 & 870 & 117 & 637 & 117 & 271 & 28 & 153 & 20 \\
\hline Tåsjö & Tasjo-4 & 16 & 1916 & 1466 & 4880 & 859 & 5131 & 1815 & 412 & 2014 & 259 & 1236 & 208 & 456 & 44 & 229 & 27 \\
\hline Tåsjö & Tasjo-4 & 17 & 2342 & 1661 & 5594 & 964 & 5876 & 2024 & 459 & 2259 & 299 & 1463 & 248 & 531 & 49 & 260 & 29 \\
\hline Tåsjö & Tasjo-4 & 18 & 2626 & 1833 & 6049 & 1032 & 6229 & 2148 & 479 & 2422 & 307 & 1505 & 250 & 529 & 54 & 261 & 31 \\
\hline Tåsjö & Tasjo-4 & 19 & 2655 & 1704 & 5504 & 946 & 5771 & 2077 & 457 & 2303 & 299 & 1447 & 242 & 529 & 52 & 262 & 36 \\
\hline Tåsjö & Tasjo-7 & 20 & 555 & 1248 & 3820 & 672 & 3887 & 1386 & 315 & 1418 & 187 & 922 & 150 & 325 & 28 & 135 & 18 \\
\hline Tåsjö & Tasjo-7 & 21 & 664 & 1295 & 3913 & 681 & 4090 & 1387 & 313 & 1611 & 199 & 1000 & 172 & 354 & 32 & 149 & 19 \\
\hline Tåsjö & Tasjo-7 & 22 & 472 & 1171 & 3390 & 507 & 2658 & 795 & 263 & 1040 & 148 & 785 & 139 & 317 & 31 & 150 & 18 \\
\hline Tåsjö & Tasjo-7 & 23 & 627 & 1013 & 2928 & 446 & 2337 & 755 & 221 & 979 & 130 & 684 & 114 & 266 & 28 & 126 & 15 \\
\hline Tåsjö & Tasjo-7 & 24 & 795 & 1094 & 3182 & 471 & 2506 & 753 & 262 & 1032 & 143 & 772 & 135 & 309 & 30 & 154 & 18 \\
\hline Tåsjö & Tasjo-7 & 25 & 1974 & 1856 & 5678 & 902 & 4978 & 1682 & 356 & 1899 & 249 & 1241 & 212 & 475 & 46 & 248 & 30 \\
\hline Tåsjö & Tasjo-7 & 26 & 870 & 1076 & 2996 & 417 & 2199 & 698 & 179 & 886 & 125 & 663 & 119 & 266 & 27 & 146 & 17 \\
\hline Tåsjö & Tasjo-7 & 27 & 887 & 1098 & 3167 & 455 & 2371 & 736 & 194 & 937 & 134 & 702 & 131 & 297 & 29 & 144 & 17 \\
\hline Tåsjö & Tasjo-7 & 28 & 548 & 1014 & 3115 & 505 & 2866 & 948 & 238 & 1112 & 143 & 741 & 120 & 280 & 23 & 126 & 15 \\
\hline Tåsjö & Tasjo-7 & 29 & 418 & 876 & 2512 & 375 & 1962 & 584 & 178 & 755 & 103 & 560 & 102 & 234 & 21 & 111 & 13 \\
\hline Tåsjö & Tasjo-7 & 30 & 322 & 817 & 2184 & 316 & 1642 & 490 & 165 & 631 & 86 & 471 & 82 & 194 & 19 & 96 & 11 \\
\hline
\end{tabular}

Table 5 Uranium and Rare Earth Element concentrations in apatite-(CaF[OH]) nodules (ppm) from LA-ICP-MS analysis 


\begin{tabular}{|c|c|c|c|c|c|c|c|c|c|c|c|c|c|}
\hline Location & Sample & Inclusion & Host rock & Type & $\begin{array}{c}\text { UV } \\
\text { color }\end{array}$ & $\begin{array}{l}\mathrm{Th} \\
{ }^{\circ} \mathrm{C} \\
\end{array}$ & $\begin{array}{l}F v \\
\%\end{array}$ & $a$ & $\beta$ & $\begin{array}{c}\mathrm{CH}_{4} \\
\mathrm{~mol} / \mathrm{kg}\end{array}$ & $\begin{array}{c}\mathrm{CO}_{2} \\
\mathrm{~mol} / \mathrm{kg}\end{array}$ & $\begin{array}{c}\text { Alk } \\
\mathrm{mol} / \mathrm{kg}\end{array}$ & $\mathrm{CH}_{2} / \mathrm{CH}_{3}$ \\
\hline Öland & Oland-3-1 & 1 & Breccia & 2-phase $\mathrm{L}+\mathrm{V}>\mathrm{L}$ & $\begin{array}{l}\text { Orange- } \\
\text { brown }\end{array}$ & 114.5 & 7.4 & 0.9239 & 0.2185 & nd & nd & nd & nd \\
\hline Öland & Oland-3-1 & 2 & Breccia & 2-phase $\mathrm{L}+\mathrm{V}>\mathrm{L}$ & $\begin{array}{l}\text { Orange- } \\
\text { brown }\end{array}$ & 121.8 & 7 & 0.9334 & 0.1763 & nd & nd & nd & nd \\
\hline Öland & Oland-3-1 & 3 & Breccia & 2-phase $\mathrm{L}+\mathrm{V}>\mathrm{L}$ & $\begin{array}{l}\text { Orange- } \\
\text { brown }\end{array}$ & 135.9 & 12.4 & 0.9086 & 0.3127 & nd & nd & nd & nd \\
\hline Öland & Oland-3-1 & 4 & Breccia & 2-phase $\mathrm{L}+\mathrm{V}>\mathrm{L}$ & $\begin{array}{l}\text { Orange- } \\
\text { brown }\end{array}$ & 142.7 & 27 & 0.8737 & 0.4894 & 36.1 & 0 & 63.9 & 3.3 \\
\hline Öland & Oland-3-3 & 1 & Breccia & $\begin{array}{c}\text { 3-phase } \\
\text { Loil+Lw+V> Loil+Lw }\end{array}$ & Blue & 134.7 & 4 & 0.9676 & 0.0149 & nd & nd & nd & nd \\
\hline Öland & Oland-3-3 & 2 & Breccia & 2-phase $L+V>L$ & Yellow & 133.1 & 5 & 0.9581 & 0.0587 & nd & nd & nd & nd \\
\hline Västergötland & Vgot-12-3 & 1 & Beef & 2-phase $\mathrm{L}+\mathrm{V}>\mathrm{L}$ & Yellow & 69.1 & 1.4 & 0.9702 & 0.0062 & 35.1 & 0.2 & 64.7 & 1.9 \\
\hline Västergötland & Vgot-12-3 & 2 & Beef & 2-phase $\mathrm{L}+\mathrm{V}>\mathrm{L}$ & Yellow & 59.3 & 3.4 & 0.9143 & 0.2837 & nd & nd & nd & nd \\
\hline Västergötland & Vgot-6-3 & 1 & Beef & 2-phase $\mathrm{L}+\mathrm{V}>\mathrm{L}$ & Yellow & 153.6 & 22 & 0.8864 & 0.4173 & 40.6 & 0.0 & 59.4 & 2.2 \\
\hline Västergötland & Vgot-1-1-4 & 1 & Fracture & 2-phase $\mathrm{L}+\mathrm{V}>\mathrm{L}$ & White & 114.1 & 21 & 0.8737 & 0.4896 & 24.9 & 0.5 & 74.5 & 1.5 \\
\hline Västergötland & Vgot-1-1-4 & 2 & Fracture & 2-phase $\mathrm{L}+\mathrm{V}>\mathrm{L}$ & Yellow & 78.1 & 6 & 0.9080 & 0.3215 & nd & nd & nd & nd \\
\hline Västergötland & Vgot-1-1-4 & 3 & Fracture & 2-phase $\mathrm{L}+\mathrm{V}>\mathrm{L}$ & Yellow & 108.2 & 11 & 0.9004 & 0.3658 & nd & nd & nd & nd \\
\hline Västergötland & Vgot-1-1-4 & 4 & Fracture & 2-phase $\mathrm{L}+\mathrm{V}>\mathrm{L}$ & Yellow & 110 & 14.5 & 0.8871 & 0.4208 & nd & nd & nd & nd \\
\hline Västergötland & Vgot-1-1-7 & 1 & Fracture & 2-phase $\mathrm{L}+\mathrm{V}>\mathrm{L}$ & Yellow & 131.3 & 13 & 0.9048 & 0.3330 & 16.9 & 2.2 & 80.9 & 1.6 \\
\hline Västergötland & Vgot-1-1-7 & 2 & Fracture & 2-phase $\mathrm{L}+\mathrm{V}>\mathrm{L}$ & White & 124.8 & 18 & 0.8839 & 0.4317 & nd & nd & nd & nd \\
\hline Västergötland & Vgot-27-1 & 1 & Fracture & 2-phase $\mathrm{L}+\mathrm{V}>\mathrm{L}$ & Blue & 116 & 25 & 0.8674 & 0.5180 & 32.7 & 0.9 & 66.4 & 0.6 \\
\hline Västergötland & Vgot-27-1 & 2 & Fracture & 2-phase $\mathrm{L}+\mathrm{V}>\mathrm{L}$ & Blue & 120 & 18 & 0.8820 & 0.4421 & 48.7 & 0.6 & 50.7 & 1.1 \\
\hline Västergötland & Vgot-27-1 & 3 & Fracture & 2-phase $\mathrm{L}+\mathrm{V}>\mathrm{L}$ & $\begin{array}{l}\text { White- } \\
\text { blue }\end{array}$ & 91.5 & 12 & 0.8839 & 0.4270 & nd & nd & nd & nd \\
\hline Västergötland & Vgot-27-1 & 4 & Fracture & 2-phase $\mathrm{L}+\mathrm{V}>\mathrm{L}$ & $\begin{array}{l}\text { White- } \\
\text { blue }\end{array}$ & 92.3 & 7.5 & 0.9086 & 0.3193 & nd & nd & nd & nd \\
\hline Västergötland & Vgot-27-1 & 5 & Fracture & 2-phase $\mathrm{L}+\mathrm{V}>\mathrm{L}$ & $\begin{array}{l}\text { White- } \\
\text { blue }\end{array}$ & 81.9 & 13 & 0.8750 & 0.4703 & 40.3 & 0.5 & 59.2 & 0.6 \\
\hline
\end{tabular}

Table 6 Main features of selected hydrocarbon-bearing inclusions in concretions and fractures. Homogenization temperatures Th are in ${ }^{\circ} \mathrm{C}$, vapor volume fractions $\mathrm{Fv}$ in $\%, \mathrm{CH}_{4}, \mathrm{CO}_{2}$ and alkane content in $\mathrm{mol} / \mathrm{kg}$ 


\begin{tabular}{|c|c|c|c|c|c|c|c|c|c|c|c|c|}
\hline Area & Sample & $C M$ & Point & D1 & D2 & D3 & D4 & $G$ & RA1 & $T\left({ }^{\circ} \mathrm{C}\right)$ & $R A 2$ & $T\left({ }^{\circ} \mathrm{C}\right)$ \\
\hline \multirow{19}{*}{ 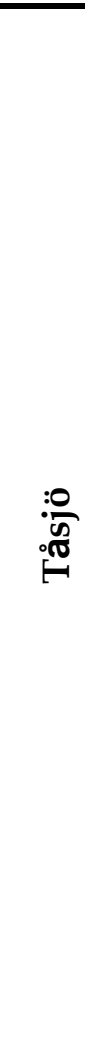 } & Tasjo-27 & PB Cal & 1 & 670836 & 132537 & 113893 & 103142 & 234020 & 0.62 & 301.50 & 1.61 & 297.99 \\
\hline & Tasjo-5 & PB & 2 & 1354690 & 236453 & 248057 & 197675 & 470816 & 0.62 & 304.05 & 1.62 & 301.10 \\
\hline & Tasjo-5 & PB & 3 & 1433390 & 247476 & 231229 & 158559 & 455712 & 0.63 & 317.92 & 1.70 & 318.60 \\
\hline & Tasjo-5 & PB & 4 & 1403070 & 184511 & 227239 & 175488 & 522092 & 0.63 & 315.63 & 1.69 & 315.64 \\
\hline & Tasjo-5 & PB & 5 & 1219620 & 211695 & 231611 & 172003 & 378355 & 0.63 & 316.20 & 1.69 & 316.37 \\
\hline & Tasjo-5 & PB & 6 & 1371480 & 191137 & 262674 & 223259 & 542331 & 0.62 & 299.65 & 1.60 & 295.76 \\
\hline & Tasjo-27 & PB Cal & 7 & 1615780 & 283507 & 341569 & 256071 & 538070 & 0.62 & 301.19 & 1.61 & 297.62 \\
\hline & Tasjo-27 & РB & 8 & 1443950 & 207717 & 249810 & 158115 & 492249 & 0.63 & 315.01 & 1.69 & 314.84 \\
\hline & Tasjo-27 & PB Cal & 9 & 580887 & 122431 & 100447 & 98073 & 188996 & 0.62 & 308.28 & 1.65 & 306.33 \\
\hline & Tasjo-27 & PB & 10 & 1506240 & 211292 & 243226 & 168281 & 532790 & 0.63 & 316.61 & 1.70 & 316.90 \\
\hline & Tasjo-27 & PV & 11 & 1463410 & 207444 & 236237 & 169841 & 509278 & 0.63 & 319.65 & 1.71 & 320.86 \\
\hline & Tasjo-27 & PB & 12 & 1564810 & 207444 & 331199 & 207585 & 565109 & 0.62 & 300.55 & 1.61 & 296.84 \\
\hline & Tasjo-27 & PB Cal & 13 & 1662280 & 254261 & 258146 & 209472 & 633528 & 0.62 & 305.58 & 1.63 & 302.97 \\
\hline & Tasjo-27 & РB & 14 & 1105440 & 212126 & 248763 & 200036 & 392691 & 0.60 & 286.06 & 1.53 & 279.87 \\
\hline & Tasjo-27 & PB Cal & 15 & 839769 & 180134 & 166554 & 128323 & 288693 & 0.60 & 284.93 & 1.52 & 278.59 \\
\hline & Tasjo-4 & $\mathrm{PB}$ & 16 & 2948170 & 209039 & 494061 & 220795 & 1376960 & 0.60 & 284.91 & 1.52 & 278.55 \\
\hline & Tasjo-4 & PV & 17 & 2724970 & 171895 & 382073 & 347236 & 1361680 & 0.62 & 300.17 & 1.60 & 296.39 \\
\hline & Tasjo-4 & PV & 18 & 2545800 & 143168 & 353244 & 324590 & 1309060 & 0.61 & 297.59 & 1.59 & 293.30 \\
\hline & Tasjo-7 & PV & 19 & 2945470 & 208986 & 506263 & 266087 & 1215560 & 0.62 & 310.91 & 1.66 & 309.63 \\
\hline \multirow{12}{*}{$\frac{\Sigma}{\dot{d}}$} & Myr-24 & $\mathrm{PV}$ & 20 & 1364120 & 247041 & 271846 & 223351 & 532447 & 0.60 & 282.23 & 1.51 & 275.55 \\
\hline & Myr-24 & PV & 21 & 1690770 & 292555 & 260231 & 159189 & 601591 & 0.62 & 299.95 & 1.60 & 296.12 \\
\hline & Myr-24 & PV & 22 & 1887640 & 303782 & 244725 & 181018 & 759944 & 0.61 & 295.94 & 1.58 & 291.33 \\
\hline & Myr-24 & PV & 23 & 1690960 & 311381 & 278922 & 231926 & 607716 & 0.62 & 300.41 & 1.61 & 296.68 \\
\hline & Myr-24 & PV & 24 & 1803980 & 327531 & 265178 & 226071 & 704740 & 0.61 & 292.85 & 1.56 & 287.70 \\
\hline & Myr-24 & $\mathrm{PB}$ & 25 & 2881280 & 464157 & 698747 & 473676 & 1063500 & 0.60 & 281.63 & 1.51 & 274.87 \\
\hline & Myr-24 & PB & 26 & 3773060 & 466108 & 805564 & 484999 & 1482730 & 0.61 & 289.27 & 1.55 & 283.54 \\
\hline & Myr-24 & $\mathrm{PB}$ & 27 & 2832140 & 439188 & 688811 & 405738 & 959538 & 0.61 & 290.26 & 1.55 & 284.68 \\
\hline & Myr-24 & PV & 28 & 2721370 & 439188 & 706834 & 634086 & 1188530 & 0.59 & 267.39 & 1.44 & 259.40 \\
\hline & Myr-24 & PV & 29 & 2525430 & 439188 & 669105 & 615141 & 1085730 & 0.59 & 266.15 & 1.43 & 258.09 \\
\hline & Myr-24 & PV & 30 & 2907760 & 420071 & 752647 & 414036 & 1050650 & 0.60 & 279.05 & 1.49 & 272.01 \\
\hline & Myr-16 & $\mathrm{PV}$ & 31 & 2607090 & 423192 & 574784 & 467270 & 1051430 & 0.60 & 280.27 & 1.50 & 273.36 \\
\hline
\end{tabular}

Table 7 Peak area and calculated temperatures for Raman spectra on carbonaceous nodules. RA1 and RA2 are two area ratios used to estimate temperature. Carbonaceous matter types (CM) are indicated as PB Cal (Pyrobitumen under calcite), PB (Pyrobitumen) and PV (Pseudo-vitrinite) 


\begin{tabular}{|c|c|c|c|c|c|c|c|c|c|c|c|}
\hline Sample & Point & $\mathrm{SiO}_{2}$ & $\mathrm{P}_{2} \mathrm{O}_{5}$ & $\mathrm{CaO}$ & $\mathrm{TiO}_{2}$ & $\mathrm{Y}_{2} \mathrm{O}_{3}$ & $\mathrm{ZrO}_{2}$ & $\mathrm{PbO}$ & $\mathrm{ThO}_{2}$ & $\mathrm{UO}_{2}$ & Total \\
\hline Tasjo-2 & 1 & 3.4 & 0 & 1.64 & 3.28 & 0 & 0 & 0 & 0 & 77.35 & 85.67 \\
\hline Tasjo-2 & 2 & 8.92 & 7.39 & 4.4 & 1.63 & 8.37 & 0 & 0 & 0 & 52.72 & 83.43 \\
\hline Tasjo-2 & 3 & 4.13 & 0 & 1.68 & 3.61 & 0 & 0 & 0 & 0 & 71.17 & 80.59 \\
\hline Tasjo-2 & 4 & 9.34 & 4.75 & 3.64 & 2.34 & 5.87 & 0 & 0 & 0 & 47.2 & 73.14 \\
\hline Tasjo-2 & 5 & 9.95 & 9.67 & 4.7 & 1.02 & 6.98 & 0 & 0 & 0 & 41.32 & 73.64 \\
\hline Tasjo-2 & 6 & 12.09 & 3.35 & 1.54 & 0.97 & 8.3 & 0 & 0 & 0 & 48.22 & 74.47 \\
\hline Tasjo-2 & 7 & 11.27 & 1.47 & 0.88 & 1.1 & 4.53 & 0 & 0 & 0 & 55.71 & 74.96 \\
\hline Tasjo-2 & 8 & 10.49 & 0 & 1.26 & 1.93 & 0 & 0 & 0 & 0 & 61.61 & 75.29 \\
\hline Tasjo-2 & 9 & 8.38 & 1.94 & 1.37 & 0.61 & 5.73 & 0 & 0 & 0 & 57.41 & 75.44 \\
\hline Tasjo-2 & 10 & 2.38 & 0 & 1.78 & 4.4 & 0 & 0 & 0 & 0 & 80.78 & 89.34 \\
\hline Tasjo-2 & 11 & 3.48 & 0 & 2.64 & 33.81 & 0 & 0 & 0 & 4.59 & 45.05 & 89.57 \\
\hline Tasjo-2 & 12 & 2.49 & 0 & 2.75 & 34.48 & 0 & 0 & 0 & 4.4 & 42.92 & 87.04 \\
\hline Tasjo-2 & 13 & 15.18 & 6.3 & 2.53 & 1.51 & 10.3 & 0 & 0 & 0 & 43.26 & 79.08 \\
\hline Tasjo-2 & 14 & 10.85 & 4.86 & 3.04 & 2.47 & 7.57 & 0 & 0 & 0 & 54.29 & 83.08 \\
\hline Tasjo-2 & 15 & 2.8 & 0 & 1.4 & 2.7 & 0 & 0 & 5.23 & 0 & 80.16 & 92.29 \\
\hline Tasjo-2 & 16 & 2.29 & 0 & 1.43 & 2.88 & 0 & 0 & 4.71 & 0 & 82.73 & 94.04 \\
\hline Tasjo-2 & 17 & 4.47 & 0 & 1.46 & 3.48 & 0 & 0 & 0 & 0 & 77.44 & 86.85 \\
\hline Tasjo-2 & 18 & 5.35 & 0 & 1.57 & 33.35 & 0 & 0 & 0 & 0 & 45.24 & 85.51 \\
\hline Tasjo-2 & 19 & 6.4 & 0 & 1.37 & 32.08 & 0 & 0 & 0 & 6.2 & 39.76 & 85.81 \\
\hline Tasjo-2 & 20 & 7.65 & 14.07 & 4.31 & 0 & 16.15 & 0 & 0 & 0 & 33.09 & 75.27 \\
\hline Tasjo-2 & 21 & 6.37 & 15.4 & 7.3 & 0 & 13.98 & 0 & 0 & 0 & 29.4 & 72.45 \\
\hline Tasjo-2 & 22 & 12.84 & 11.21 & 6.36 & 0.76 & 6.5 & 0 & 0 & 0 & 36.47 & 74.14 \\
\hline Tasjo-2 & 23 & 11.03 & 7.82 & 4.13 & 1.23 & 6.27 & 0 & 0 & 0 & 45.65 & 76.13 \\
\hline Tasjo-4 & 24 & 3.61 & 0 & 2.21 & 32.43 & 0 & 0 & 0 & 0 & 44.74 & 82.99 \\
\hline Tasjo-4 & 25 & 3.6 & 0 & 1.57 & 32.93 & 0 & 0 & 0 & 7.59 & 39.07 & 84.76 \\
\hline Tasjo-4 & 26 & 7.17 & 21.67 & 4.36 & 0 & 22.44 & 0 & 0 & 8.8 & 10.06 & 74.5 \\
\hline Tasjo-4 & 27 & 8.5 & 4.27 & 0.9 & 0 & 6.2 & 0 & 0 & 13.67 & 42.33 & 75.87 \\
\hline Tasjo-4 & 28 & 6.88 & 3.84 & 1.09 & 1.27 & 4.76 & 0 & 0 & 12.41 & 44.45 & 74.7 \\
\hline Tasjo-2 & 29 & 7.17 & 12.82 & 4.56 & 2.08 & 14.12 & 0 & 0 & 0 & 29.26 & 70.01 \\
\hline Tasjo-2 & 30 & 12.55 & 2.94 & 4.01 & 5.97 & 5.09 & 16.29 & 0 & 0 & 28.56 & 75.41 \\
\hline Tasjo-2 & 31 & 10.67 & 5.95 & 4.39 & 0 & 6.82 & 7.2 & 3.96 & 0 & 34.91 & 73.9 \\
\hline Tasjo-2 & 32 & 7.5 & 14.85 & 4.17 & 1.84 & 16.98 & 0 & 0 & 0 & 30.94 & 76.28 \\
\hline Tasjo-2 & 33 & 15.3 & 4.03 & 3.44 & 0 & 6.5 & 13.78 & 0 & 6.28 & 20.86 & 70.19 \\
\hline Tasjo-2 & 34 & 4.26 & 0.08 & 1.61 & 4.64 & 0 & 1.48 & 1.94 & 0 & 78.51 & 92.52 \\
\hline Tasjo-2 & 35 & 8.67 & 0.3 & 0.67 & 8.39 & 0 & 0.65 & 0.07 & 0 & 65.95 & 84.7 \\
\hline Tasjo-2 & 36 & 5.87 & 1.91 & 1.95 & 31.97 & 1.16 & 0 & 0 & 0 & 41.6 & 84.46 \\
\hline Tasjo-2 & 37 & 6.56 & 0.72 & 2.59 & 15.3 & 0 & 1.3 & 2.04 & 0 & 52.93 & 81.44 \\
\hline Tasjo-2 & 38 & 10.31 & 8.84 & 6.41 & 1.42 & 7.28 & 4.15 & 0 & 0 & 41.07 & 79.48 \\
\hline Tasjo-2 & 39 & 9.77 & 6.64 & 5.64 & 0 & 6.58 & 6.6 & 0 & 1.65 & 38.16 & 75.04 \\
\hline Tasjo-2 & 40 & 5.06 & 2.05 & 3.33 & 7.92 & 1.26 & 0.91 & 1.64 & 0 & 65.81 & 87.98 \\
\hline Tasjo-2 & 41 & 4.37 & 0.83 & 2.27 & 30.87 & 2.1 & 0 & 0.55 & 0 & 40.69 & 81.68 \\
\hline Tasjo-2 & 42 & 14.4 & 5.41 & 4.94 & 1.62 & 6.55 & 10.96 & 1.95 & 0 & 39.56 & 85.39 \\
\hline Tasjo-2 & 43 & 9.51 & 8.44 & 3.62 & 0 & 7.59 & 0 & 0 & 0 & 43.63 & 72.79 \\
\hline Tasjo-2 & 44 & 13.26 & 7.57 & 4 & 0 & 10.36 & 9.63 & 1.46 & 0 & 29.25 & 75.53 \\
\hline Tasjo-12 & 45 & 10.92 & 9.53 & 3.46 & 0 & 9.25 & 0 & 0 & 12.67 & 32.21 & 78.04 \\
\hline Tasjo-12 & 46 & 7.98 & 11.5 & 2.91 & 0 & 11.16 & 0 & 0 & 0 & 36.45 & 70 \\
\hline Tasjo-12 & 47 & 10.92 & 7.54 & 2.6 & 0 & 12.48 & 0 & 0 & 0 & 39.56 & 73.1 \\
\hline Tasjo-12 & 48 & 8.67 & 11.59 & 3.8 & 0 & 12.19 & 0 & 0 & 0 & 38.7 & 74.95 \\
\hline Tasjo-12 & 49 & 15.96 & 0 & 1.9 & 0 & 5.34 & 0 & 0 & 0 & 53.07 & 76.27 \\
\hline Tasjo-12 & 50 & 2.08 & 0 & 1.78 & 28.29 & 0 & 0 & 0 & 0 & 39.98 & 72.13 \\
\hline Tasjo-12 & 51 & 9.63 & 7.61 & 2.48 & 0 & 8.42 & 0 & 0 & 0 & 43.71 & 71.85 \\
\hline Tasjo-12 & 52 & 11.2 & 2.7 & 2.2 & 9.95 & 0 & 0 & 0 & 0 & 46.08 & 72.13 \\
\hline Tasjo-12 & 53 & 7.97 & 15.13 & 4.23 & 0 & 16.17 & 0 & 0 & 0 & 33.91 & 77.41 \\
\hline Tasjo-12 & 54 & 6.09 & 0 & 0 & 27.92 & 2.46 & 0 & 0 & 0 & 36.83 & 73.3 \\
\hline Tasjo-13 & 55 & 11.21 & 3.53 & 2.87 & 2.37 & 0 & 0.94 & 0 & 0 & 54.57 & 75.49 \\
\hline Tasjo-13 & 56 & 11.75 & 3.03 & 2.54 & 0 & 0.72 & 1.25 & 0 & 0 & 57.35 & 76.64 \\
\hline Tasjo-13 & 57 & 12.64 & 3.04 & 2.24 & 9.23 & 0 & 0 & 0 & 0 & 45.22 & 72.37 \\
\hline Tasjo-13 & 58 & 9.8 & 3.23 & 2.62 & 1.59 & 0.69 & 1.08 & 0 & 0 & 51.62 & 70.63 \\
\hline Tasjo-13 & 59 & 9.05 & 2.75 & 1.38 & 19.04 & 0 & 0 & 0 & 0 & 44.75 & 76.97 \\
\hline
\end{tabular}




\begin{tabular}{|c|c|c|c|c|c|c|c|c|c|c|c|}
\hline Sample & Point & $\mathrm{SiO}_{2}$ & $\mathrm{P}_{2} \mathrm{O}_{5}$ & $\mathrm{CaO}$ & $\mathrm{TiO}_{2}$ & $\mathrm{Y}_{2} \mathrm{O}_{3}$ & $\mathrm{ZrO}_{2}$ & $\mathrm{PbO}$ & $\mathrm{ThO}_{2}$ & $\mathrm{UO}_{2}$ & Total \\
\hline Tasjo-13 & 60 & 10.78 & 3.33 & 2.58 & 4.42 & 0 & 0 & 0 & 0 & 54.21 & 75.32 \\
\hline Tasjo-13 & 61 & 9.55 & 2.96 & 2.65 & 12.16 & 0 & 0 & 0 & 0 & 48.88 & 76.2 \\
\hline Tasjo-13 & 62 & 10.31 & 4.3 & 3.63 & 9.57 & 0 & 0 & 0 & 0 & 49.83 & 77.64 \\
\hline Tasjo-13 & 63 & 9.51 & 2.7 & 2.14 & 6.39 & 0 & 0 & 0 & 0 & 52.98 & 73.72 \\
\hline Tasjo-36 & 64 & 15.93 & 1.55 & 3.52 & 11.32 & 0.24 & 0 & 0 & 0 & 54.64 & 87.2 \\
\hline Tasjo-36 & 65 & 16.2 & 1.83 & 3.45 & 8.93 & 0.48 & 0.17 & 0 & 0 & 55.53 & 86.59 \\
\hline Tasjo-36 & 66 & 18.25 & 0.96 & 2.99 & 5.41 & 0 & 0.58 & 0 & 0 & 46 & 74.19 \\
\hline Tasjo-36 & 67 & 15.68 & 0.84 & 2.94 & 5.81 & 0 & 0.75 & 0 & 0 & 56.31 & 82.33 \\
\hline Tasjo-36 & 68 & 16.21 & 1 & 2.49 & 12.45 & 0 & 0.79 & 0 & 0 & 53.83 & 86.77 \\
\hline Tasjo-36 & 69 & 20.7 & 1.71 & 2.96 & 2.31 & 0.97 & 0 & 0 & 0 & 52.54 & 81.19 \\
\hline Tasjo-36 & 70 & 13.08 & 2.61 & 3.18 & 6.33 & 0 & 4.61 & 0 & 0 & 45.02 & 74.83 \\
\hline Tasjo-36 & 71 & 13.11 & 0.85 & 0.87 & 5 & 0 & 2.02 & 0 & 0 & 50.11 & 71.96 \\
\hline Tasjo-36 & 72 & 8.56 & 3.03 & 3.77 & 19.46 & 0 & 1.47 & 1.51 & 0 & 38.26 & 76.06 \\
\hline Tasjo-36 & 73 & 13.56 & 2.24 & 3.8 & 0 & 0.49 & 0.48 & 0.35 & 0 & 58.14 & 79.06 \\
\hline Tasjo-36 & 74 & 15.61 & 2.6 & 5.04 & 1.73 & 0 & 0 & 0 & 0 & 58.79 & 83.77 \\
\hline Tasjo-36 & 75 & 12.42 & 2.23 & 4.22 & 6.07 & 0.83 & 1.2 & 0.84 & 0 & 55.95 & 83.76 \\
\hline Tasjo-36 & 76 & 14.94 & 3.02 & 4.1 & 7.65 & 0 & 0 & 0.76 & 0 & 56.69 & 87.16 \\
\hline Tasjo-36 & 77 & 11.9 & 4.92 & 7.1 & 15.83 & 0 & 0 & 0 & 0 & 47.43 & 87.18 \\
\hline Tasjo-36 & 78 & 16.17 & 2.66 & 3.73 & 3.49 & 0 & 0 & 1.24 & 0 & 63.05 & 90.34 \\
\hline Tasjo-36 & 79 & 15.31 & 2.39 & 3.66 & 1.91 & 0 & 1.53 & 0.25 & 0 & 61.98 & 87.03 \\
\hline Tasjo-36 & 80 & 7.64 & 1.17 & 2.7 & 2.13 & 0 & 0 & 1.16 & 0 & 56.58 & 71.38 \\
\hline Tasjo-36 & 81 & 11.32 & 1 & 1.14 & 16.59 & 0.73 & 0 & 0 & 0 & 55.7 & 86.48 \\
\hline Tasjo-36 & 82 & 13.03 & 3.06 & 4.37 & 6.69 & 0 & 0 & 0 & 0 & 49.76 & 76.91 \\
\hline Tasjo-36 & 83 & 15.92 & 2.19 & 3.93 & 2.08 & 0 & 0 & 0 & 0 & 55.99 & 80.11 \\
\hline Tasjo-36 & 84 & 4.2 & 0.11 & 1.99 & 0 & 1.02 & 0 & 2.35 & 0 & 83.71 & 93.38 \\
\hline Tasjo-36 & 85 & 4.67 & 0.56 & 0 & 0 & 1.05 & 0 & 0 & 0 & 84.58 & 90.86 \\
\hline Tasjo-36 & 86 & 14.75 & 3.26 & 4.11 & 18.15 & 0 & 0 & 0 & 0 & 51.97 & 92.24 \\
\hline Tasjo-36 & 87 & 16.14 & 5.38 & 5.04 & 6.31 & 0 & 0 & 0.31 & 0 & 60.08 & 93.26 \\
\hline Tasjo-36 & 88 & 17.89 & 3.87 & 4.05 & 0 & 0 & 1.37 & 0.31 & 0 & 64.57 & 92.06 \\
\hline Tasjo-36 & 89 & 17.81 & 4.57 & 4.51 & 1.94 & 0 & 0 & 1.29 & 0 & 66.38 & 96.5 \\
\hline Tasjo-36 & 90 & 5.63 & 0.41 & 2.05 & 0 & 0 & 0 & 0 & 0 & 83.88 & 91.97 \\
\hline Tasjo-36 & 91 & 4.27 & 0.39 & 1.41 & 0 & 0 & 0 & 0 & 0 & 86.19 & 92.26 \\
\hline Tasjo-36 & 92 & 6.04 & 0.72 & 1.42 & 2.25 & 0 & 0 & 0.7 & 0.11 & 75.75 & 86.99 \\
\hline
\end{tabular}

Table 8 Composition of U-Ti bearing minerals in Alum Shale determined by EPMA in weight percents of major oxides 


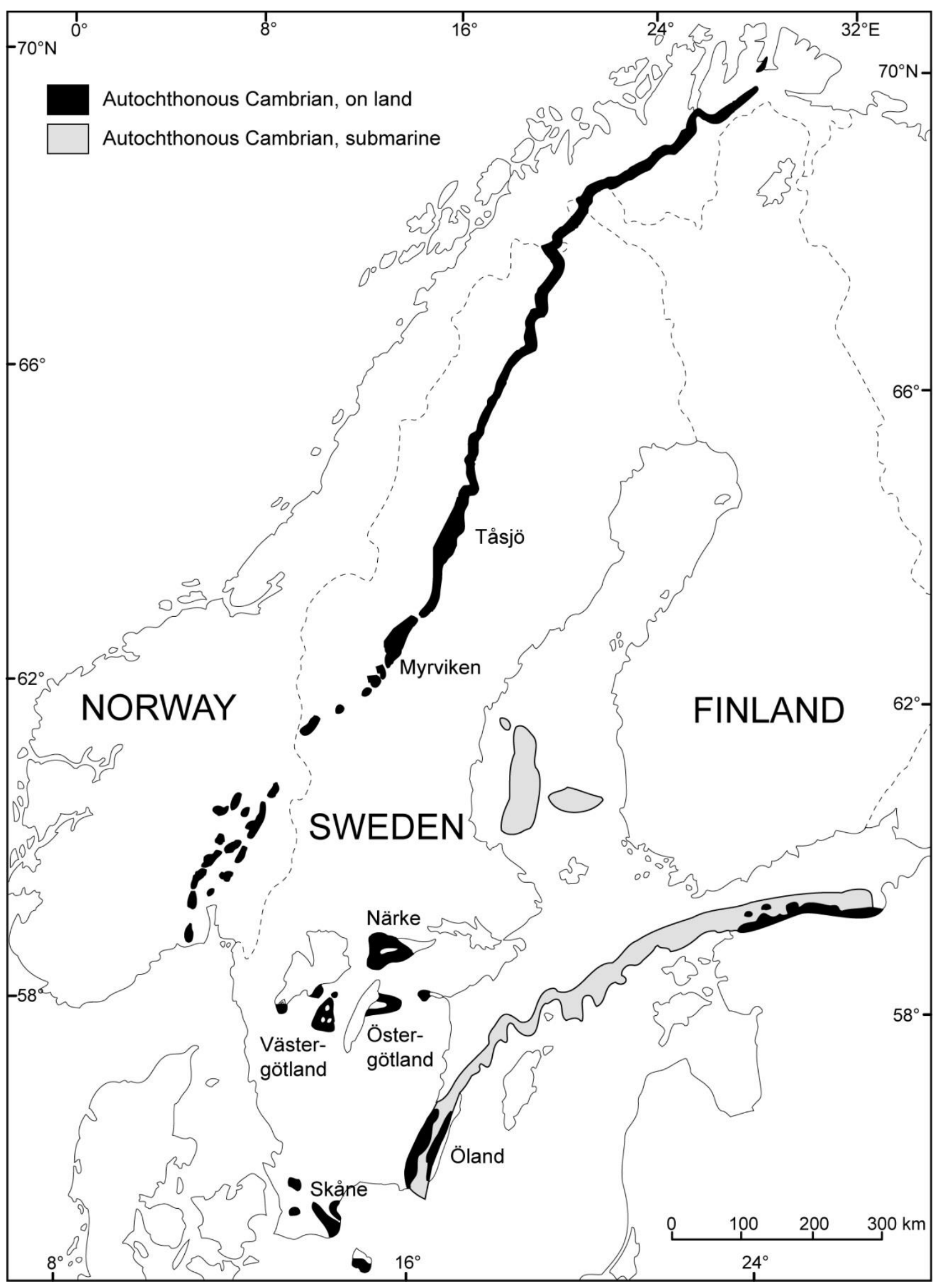

Fig. 1 Geological map of the Fennoscandian Shield with main Alum Shale occurrences (modified from Thickpenny, 1984). For a more comprehensive map of Lower Palaeozoic strata in Baltoscandia see Nielsen and Schovsbo (2015). 

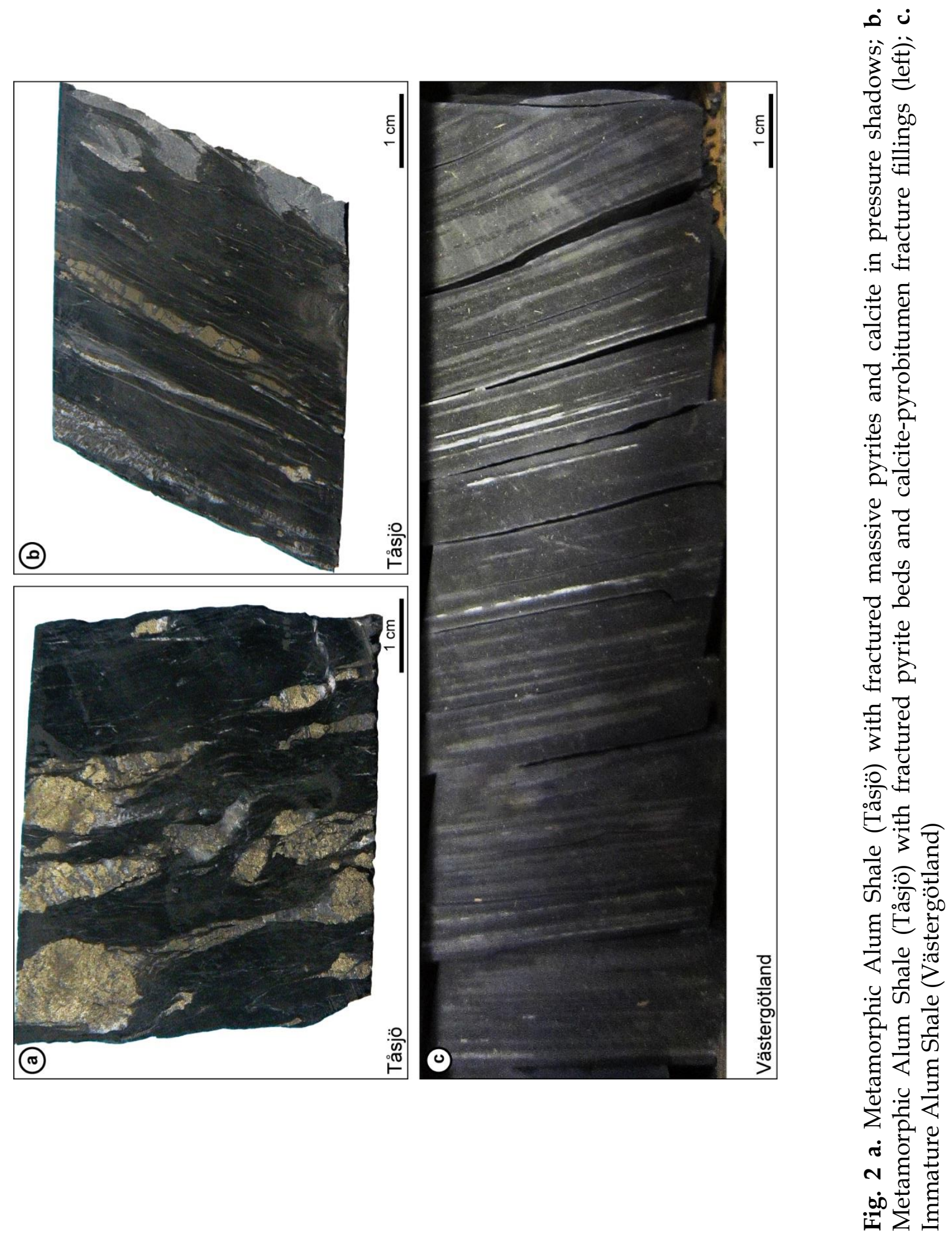


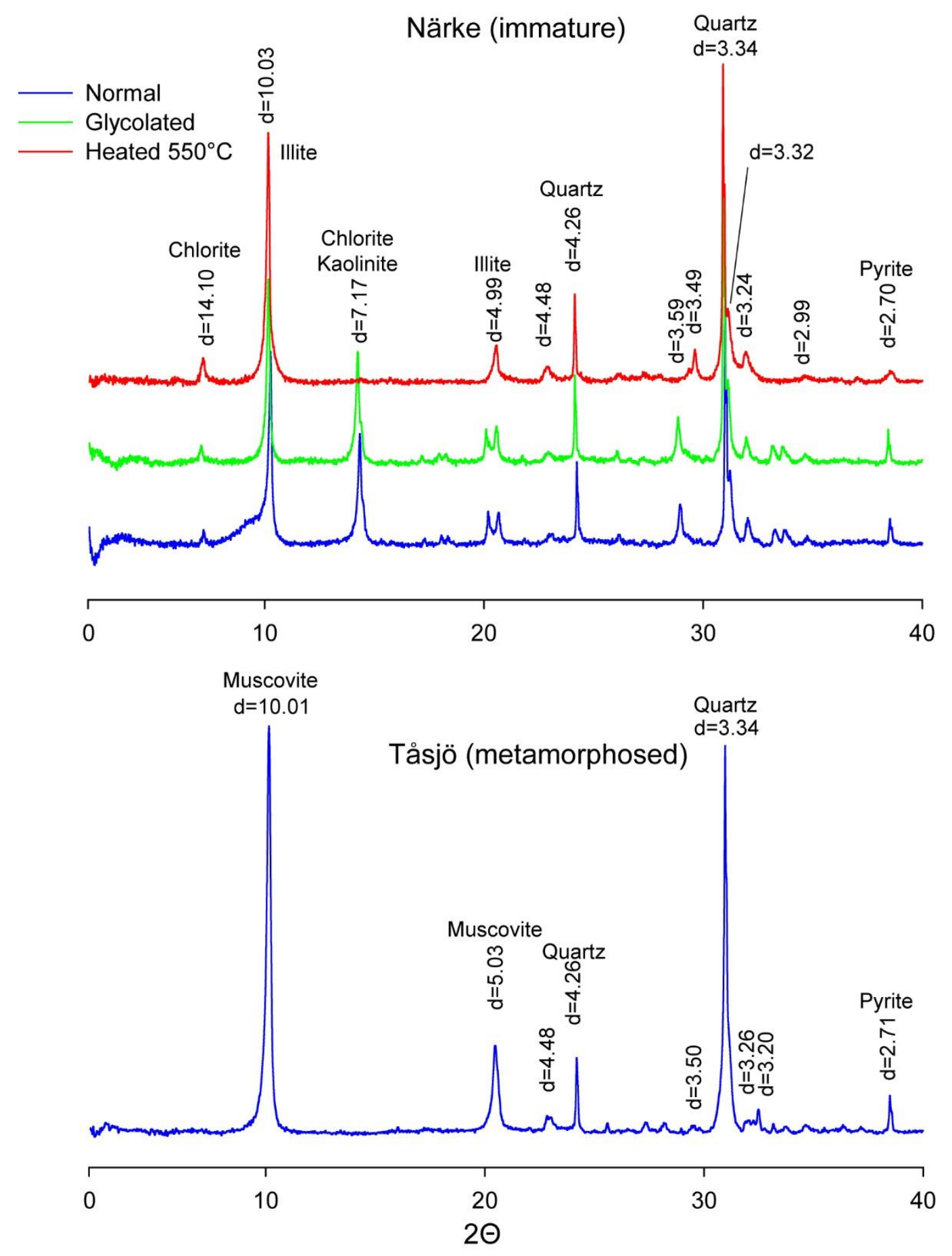

Fig. 3 X-Ray diffractograms of immature Alum Shale (Närke) and metamorphic Alum Shale (Tåsjö) 


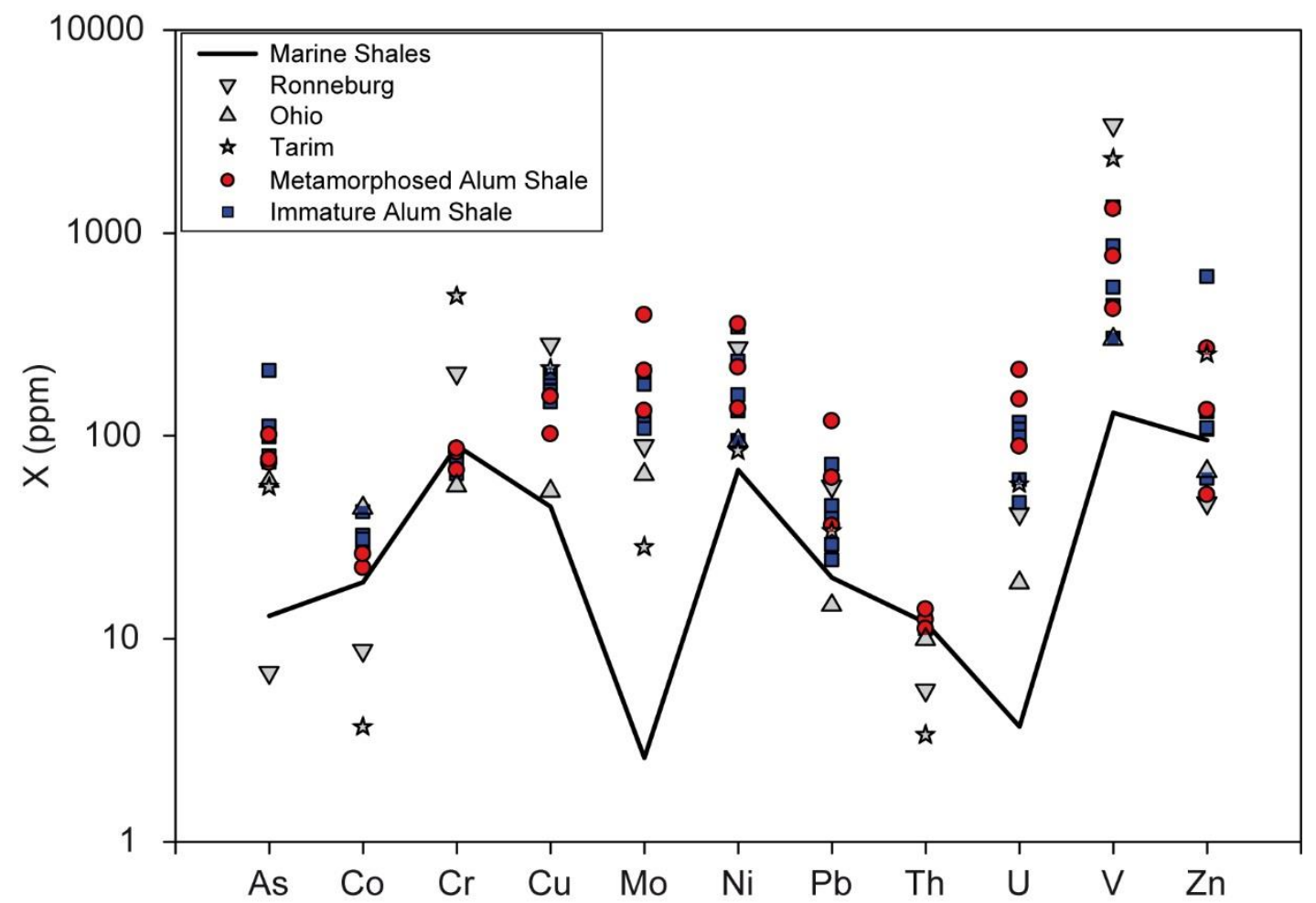

Fig. 4 Average concentrations (As, Co, Cr, Cu, Mo, $\mathrm{Ni}, \mathrm{Pb}, \mathrm{Th}, \mathrm{U}, \mathrm{V}, \mathrm{Zn}$ ) in Alum Shale occurrences analyzed for this study (dots for metamorphic samples from Myrviken, Lövstrand and Tåsjö, squares for non metamorphic samples from Närke, Östergötland, Öland, Skåne, Västergötland), compared with reference shales (Marine shales from Turekian and Wedepohl, 1961; Tarim basin black shales from Yu et al., 2009; Ronneburg black shales from Lippmaa et al., 2011; Ohio shale from Lewis et al., 2010) 

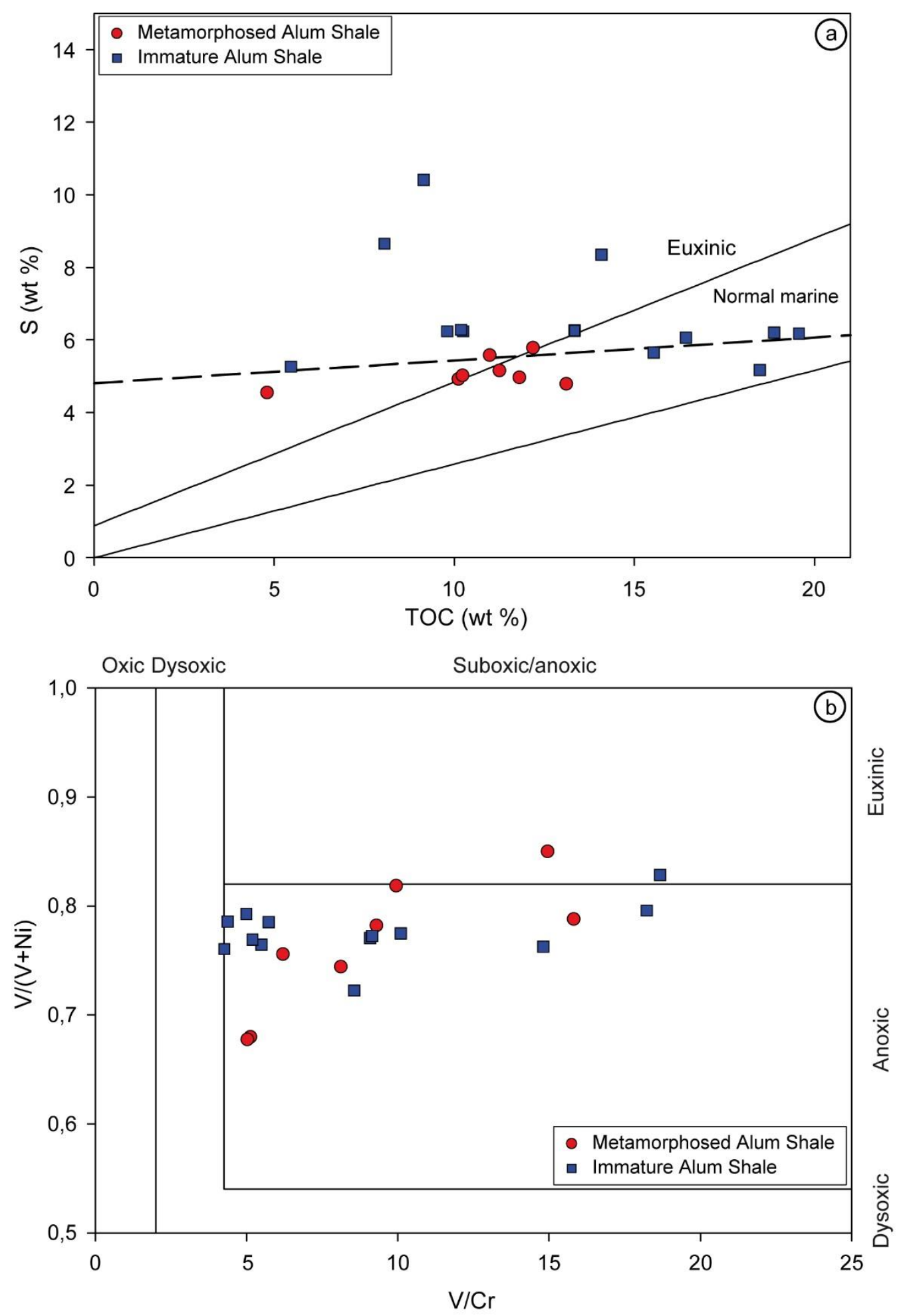

Fig. 5 a. Carbon-sulfur plot for the Alum Shale Formation. Oxic marine depositional settings and euxinic (anoxic-sulfidic) water column are indicated. Euxinic but Felimited sediments would plot along a sub-horizontal trend with an extrapolated positive intercept on the S-axis (Raiswell and Berner, 1985; Leventhal, 1995). b. V/(V + $\mathrm{Ni})$ vs. $\mathrm{V} / \mathrm{Cr}$ crossplot for the Alum Shale Formation. Depositional settings ranges for $\mathrm{V} / \mathrm{Cr}$ and $\mathrm{V} /(\mathrm{V}+\mathrm{Ni})$ are from Jones and Manning (1994) and from Hatch and Leventhal (1992), respectively 

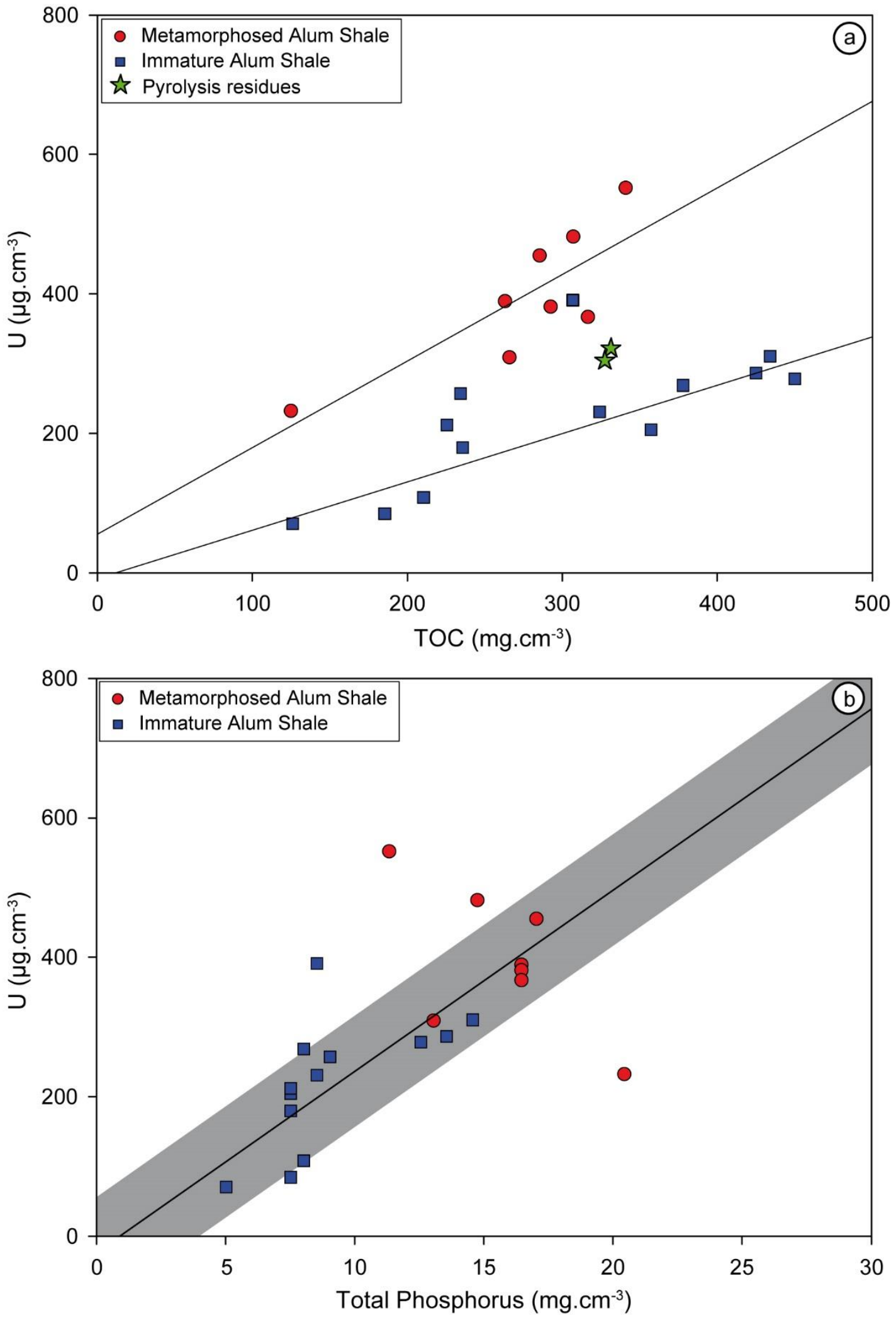

Fig. 6 Uranium-carbon plot (a) and uranium-phosphorus plot (b) for several Alum Shale occurrences. All values are density-corrected. Artificial maturation residues are indicated in Fig. $6 a$ 

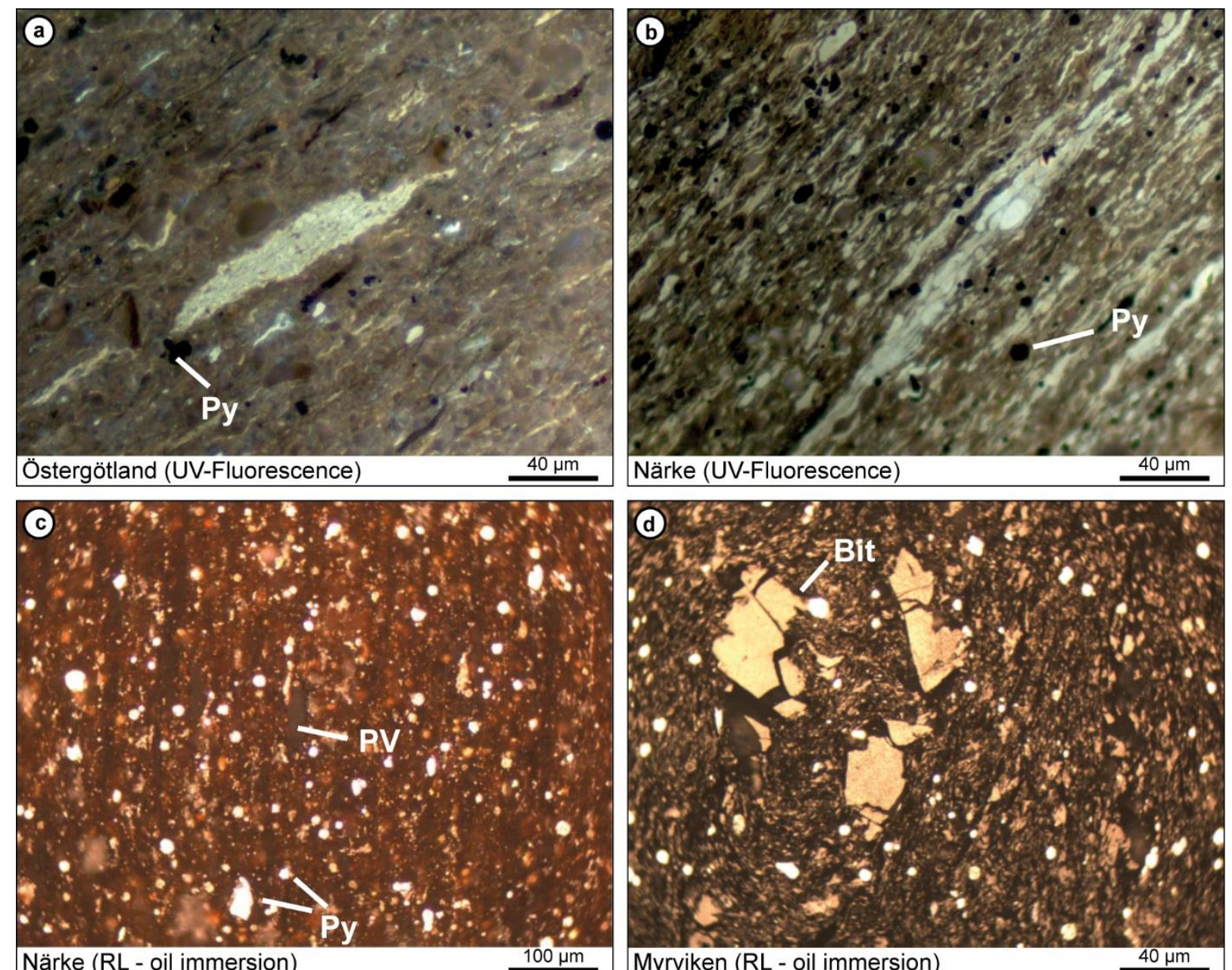

Närke (RL - oil immersion)

$100 \mu \mathrm{m}$
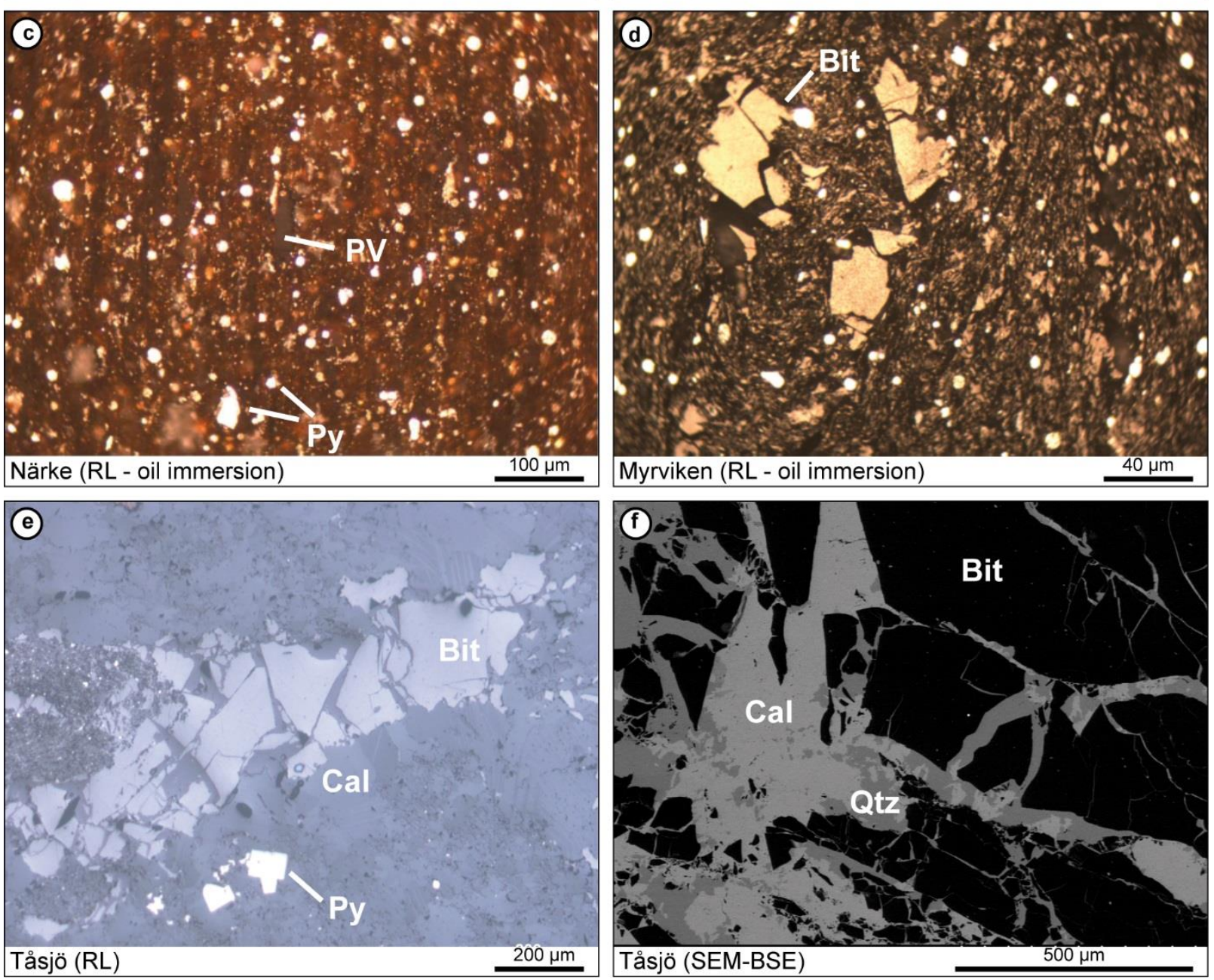

Fig. 7 Petrographic features of organic matter in the Alum Shale Formation. a. UVFluorescent macerals (liptinite) in immature Alum Shale (Östergötland); b. UV-Fluorescent macerals (liptinite) in immature Alum Shale (Närke); c. Pseudo-vitrinite in immature Alum Shale (Närke); d. Pyrobitumen in metamorphic Alum Shale (Myrviken); e. Pyrobitumen vein in metamorphic Alum Shale (Tåsjö); f. Pyrobitumen vein (with calcite) in metamorphic Alum Shale (Tåsjö). Bit: pyrobitumen, Cal: calcite, PV: pseudo-vitrinite, Pyr: pyrite, Qtz:quartz 


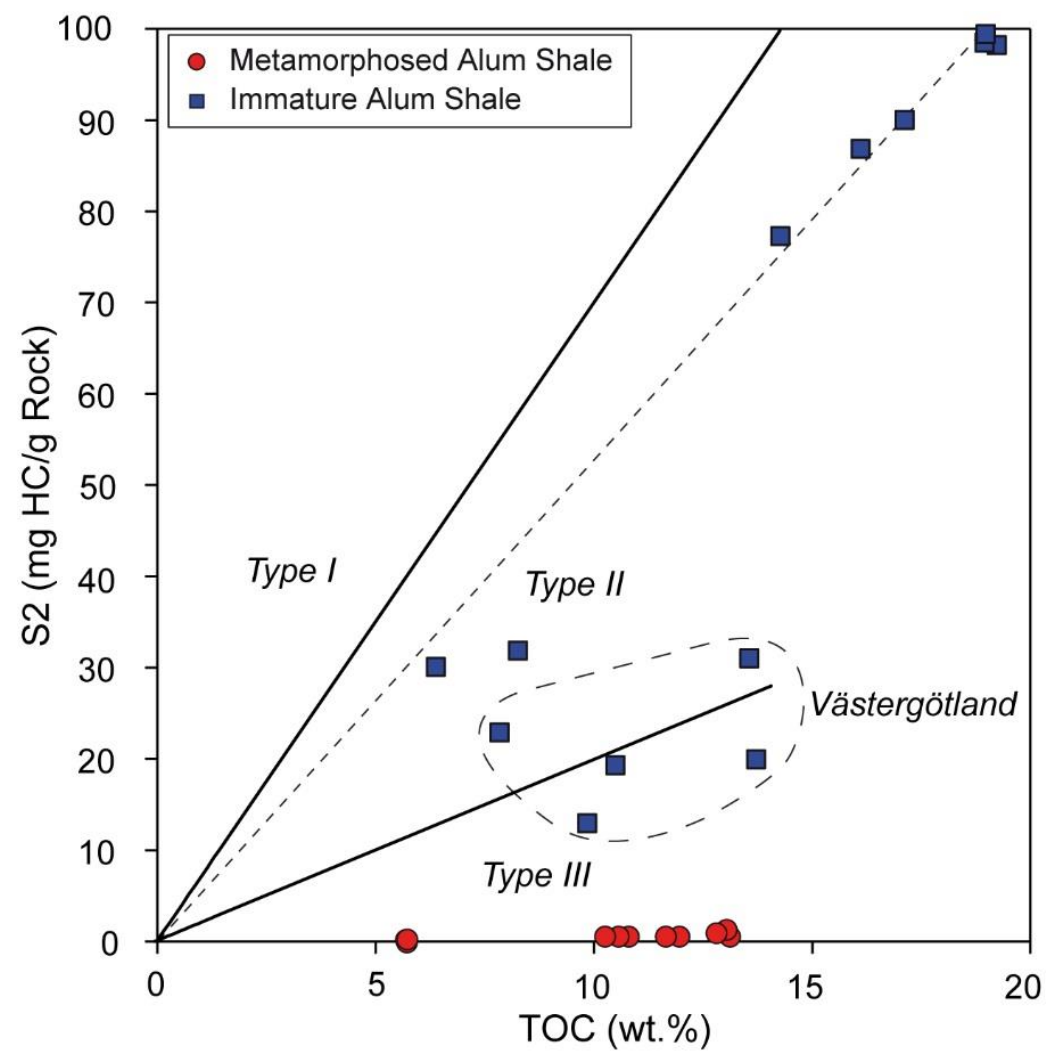

Fig. 8 S2 vs. TOC diagram for immature and metamorphic Alum Shale

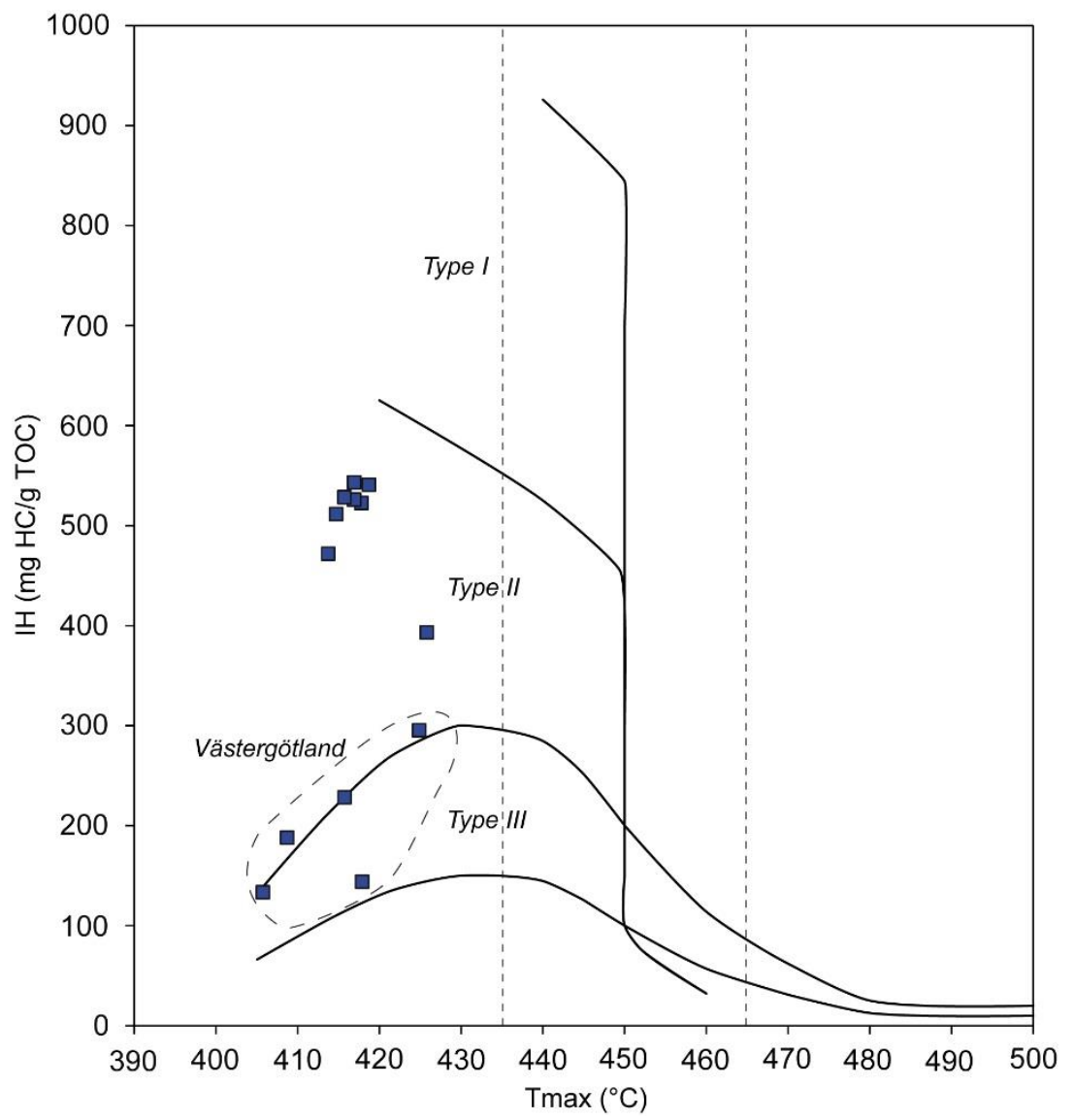

Fig. $9 \mathrm{IH}$ vs. Tmax diagram for immature and metamorphic Alum Shale 


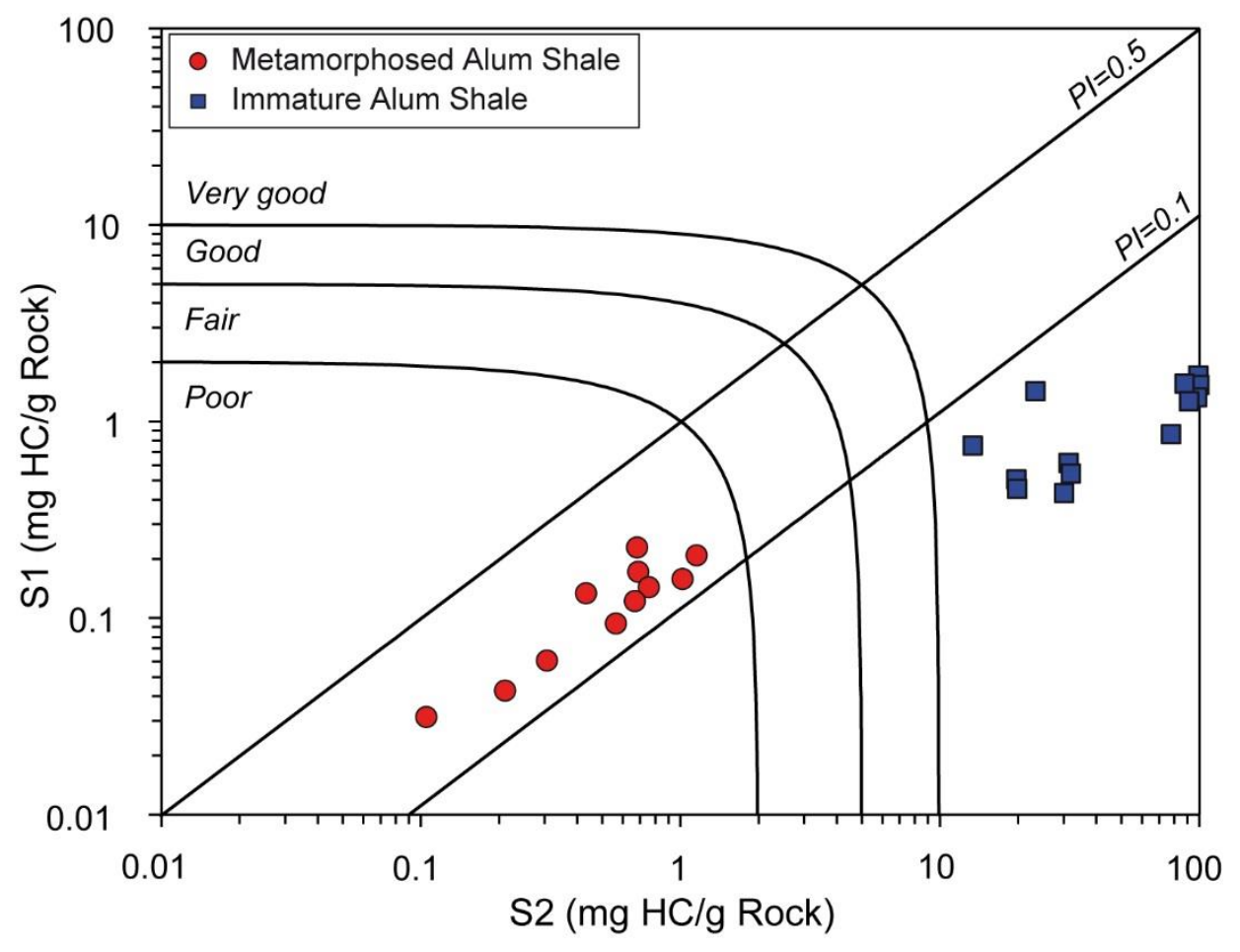

Fig. $10 \mathrm{~S} 1$ vs. S2 diagram for immature and metamorphic Alum Shale 

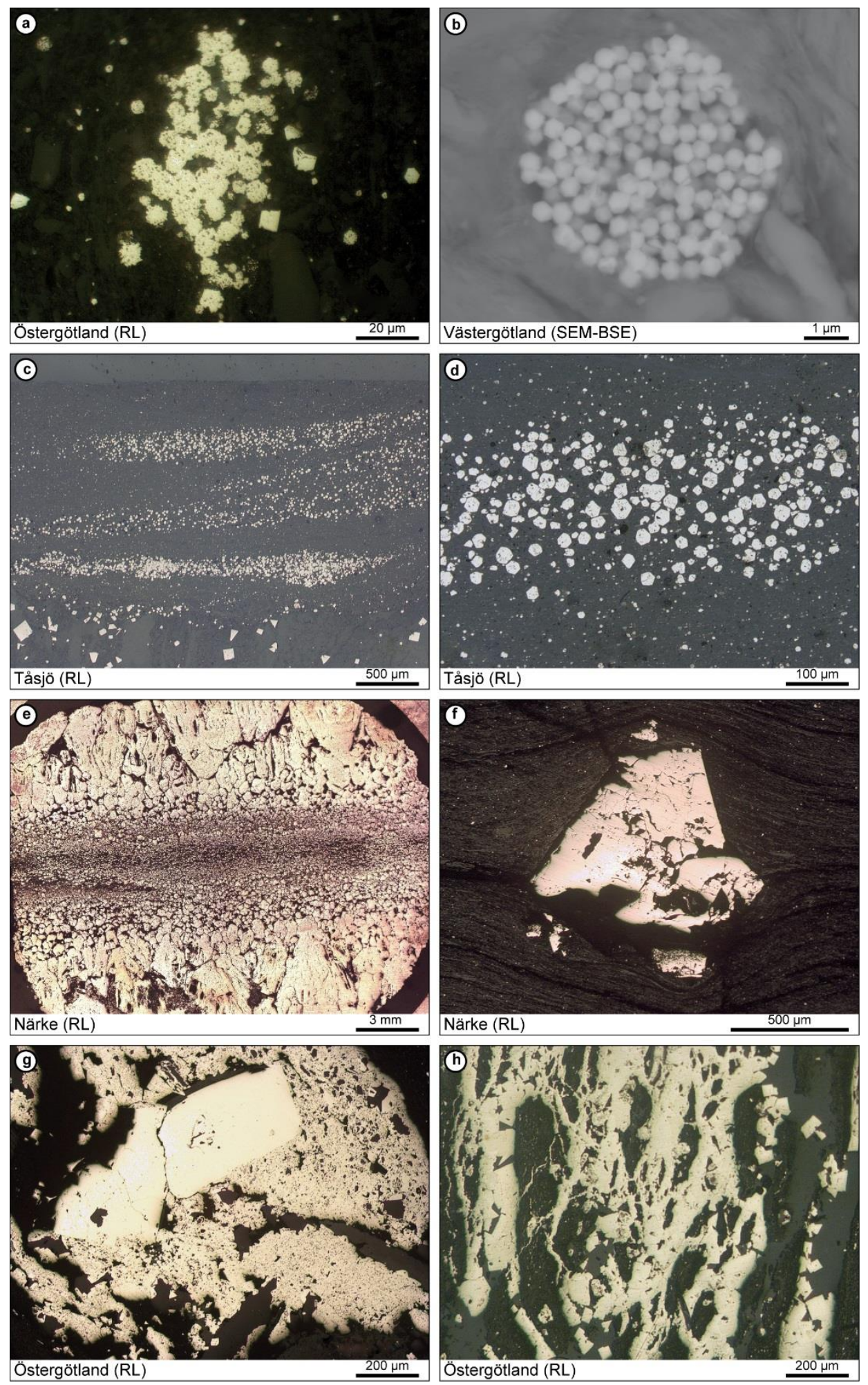

Fig. 11 Petrographic features of sedimentary and diagenetic sulfides. a. Framboids and euhedral pyrites in immature Alum Shale (Östergötland); b. Detailed view of an isolated framboid (Västergötland); c. Beds of (sub)euhedral pyrites underlining sedimentary(Tåsjö); d. Beds of (sub)euhedral pyrites (Tåsjö); e. Massive pyrite with core of coalescent syn-sedimentary pyrites and large pyrite crystals growing perpendicularly (Närke); f. Large isolated pyrite and deformation of sedimentary bedding (Närke); g. Massive pyrites in heterogeneous porous cement (Östergötland); h. Homogeneous pyrite veins and fracture fillings of euhedral pyrites (Östergötland) 

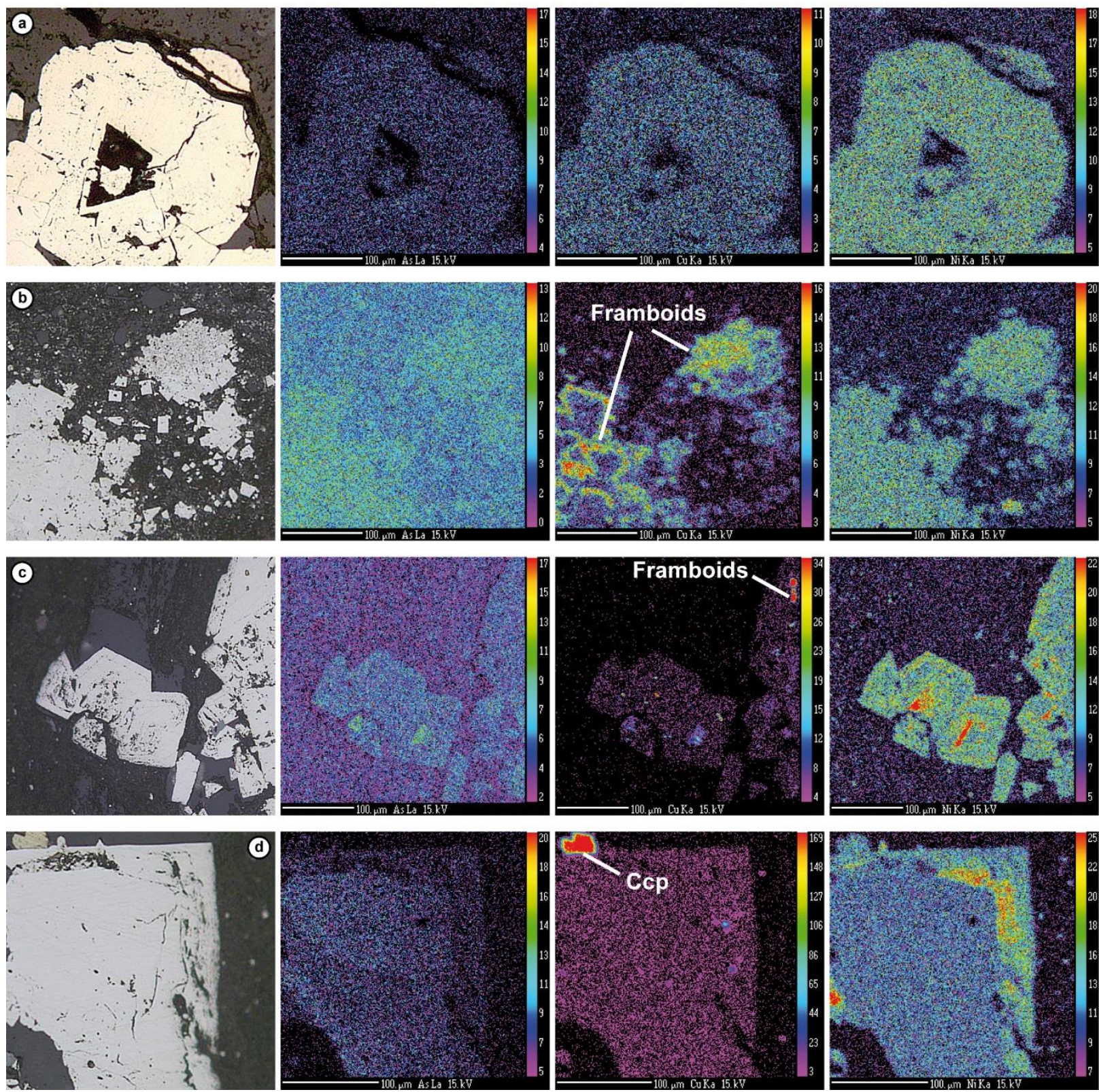

Fig. $12 \mathrm{As}, \mathrm{Cu}$ and $\mathrm{Ni}$ content in sulfides from immature and metamorphic Alum Shale. a. Diagenetic pyrite with no particular enrichment in $\mathrm{As}, \mathrm{Cu}$ and $\mathrm{Ni}$; b. Framboids with high $\mathrm{Cu}$ concentration compared to syngenetic euhedral pyrites; $\mathbf{c}$. Synmetamorphic pyrite overgrowth with Ni enrichment and framboids remnants with high $\mathrm{Cu}$ concentration; $\mathbf{d}$. Massive diagenetic pyrite with no particular enrichment and metamorphic overgrowths with Ni-rich pyrite and chalcopyrite (Ccp) 

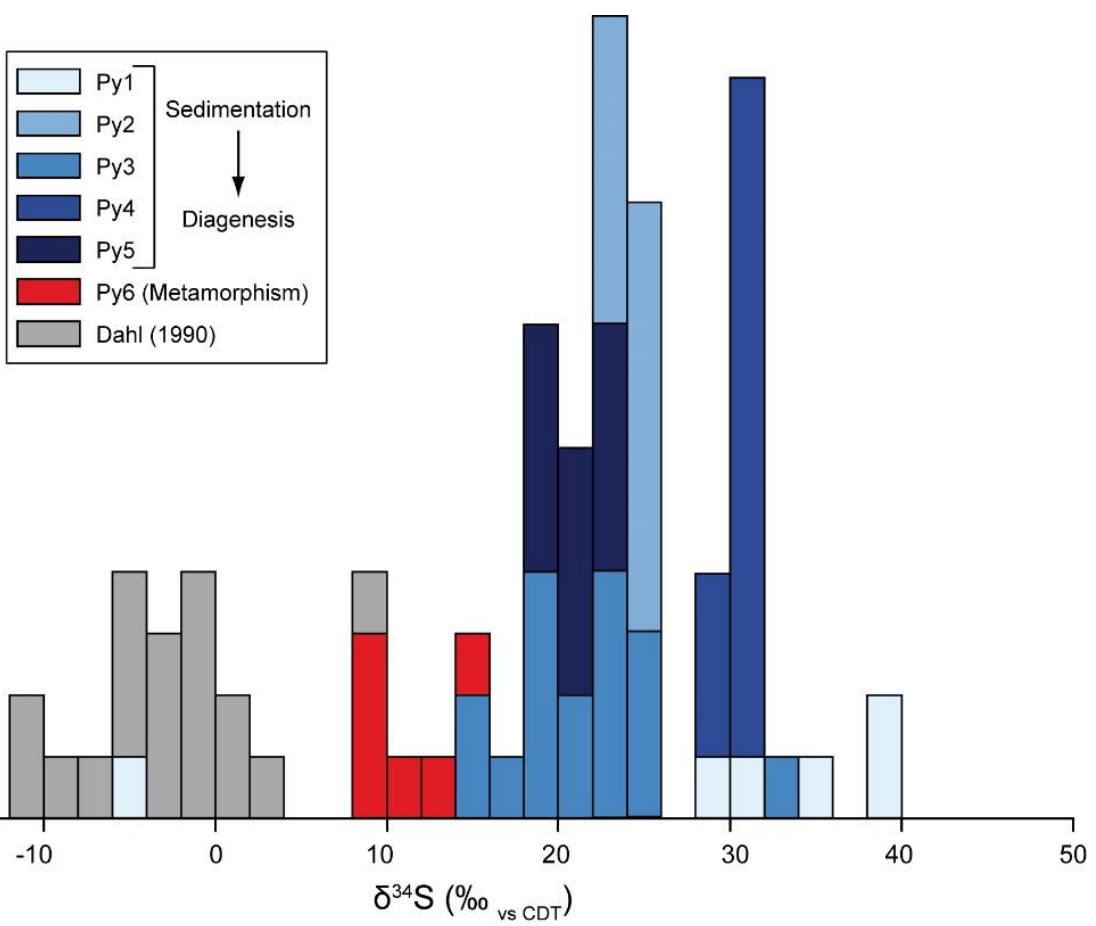

Fig. 13 Histogram of $\delta^{34} S$ values of pyrite in the Alum Shale Formation 

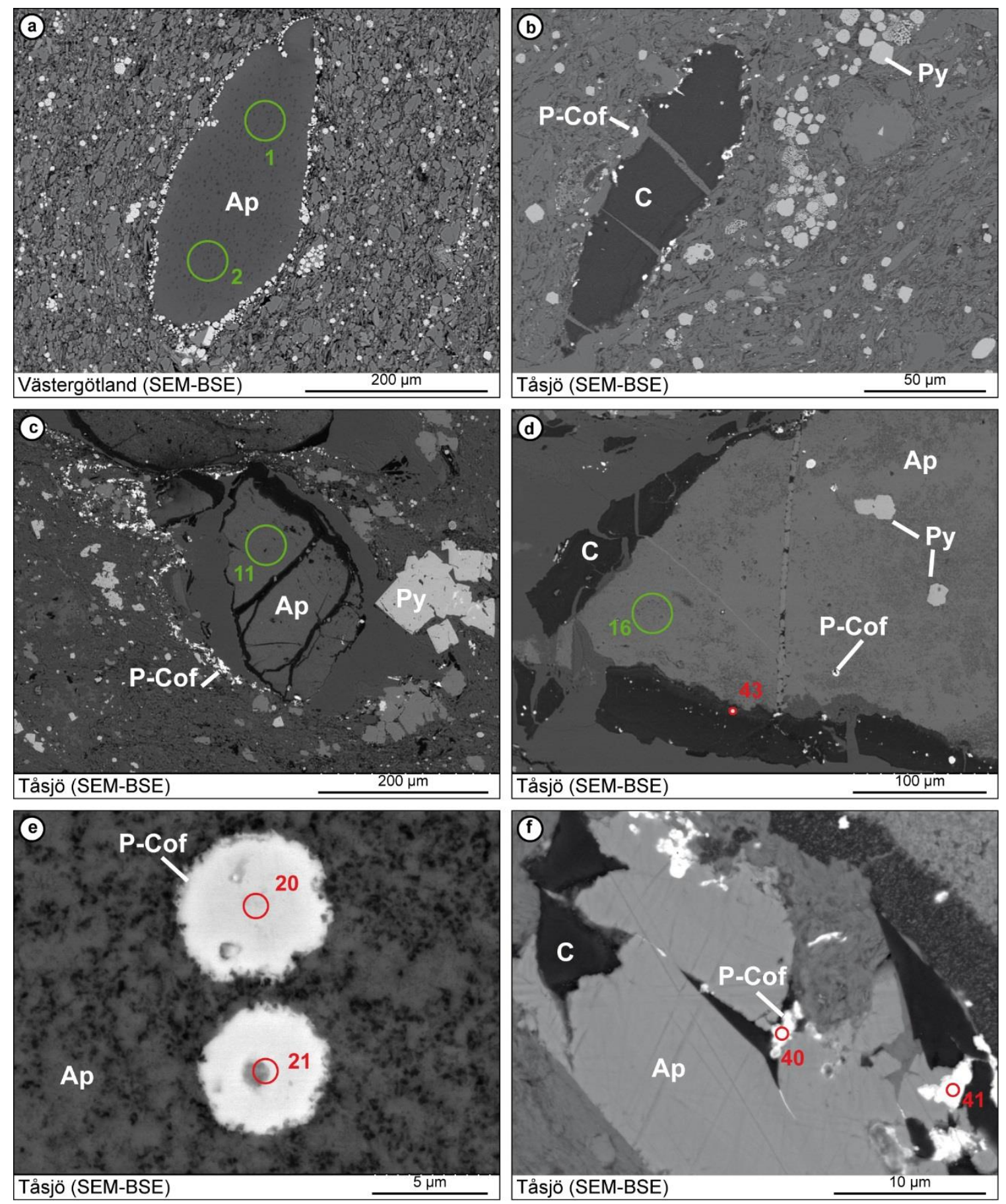

Fig. 14 a. Apatite-(CaF[OH]) nodule surrounded by pyrites in immature Alum Shale (Östergötland); $b$. Carbonaceous matter veinlet (black) with uranium phospho-silicates (white) and syn-sedimentary pyrites (light grey) in metamorphic Alum Shale (Tåsjö); c. Porous apatite-(CaF[OH]) nodule surrounded by uranium phospho-silicates clusters (white) in metamorphic Alum Shale (Tåsjö); d. Porous apatite- $(\mathrm{CaF}[\mathrm{OH}])$ nodule surrounded by carbonaceous matter and uranium phospho-silicates clusters (white) in metamorphic Alum Shale (Tåsjö); e. Uranium phospho-silicates spherulites inside apatite-(CaF[OH]) nodule (Tåsjö); f. Apatite- $(\mathrm{CaF}[\mathrm{OH}])$ anhedral crystals associated with uranium phospho-silicates and carbonaceous matter on the edge of a porous apatite-(CaF[OH]) nodule (Tåsjö). Ap: apatite-(CaF[OH]), C: carbonaceous matter, P-cof: uranium phospho-silicates of various composition (see text for details), Py: pyrite. Red circles and green circles correspond to uranium minerals chemical analyses and phosphate nodules LA-ICP/MS analyses, respectively 

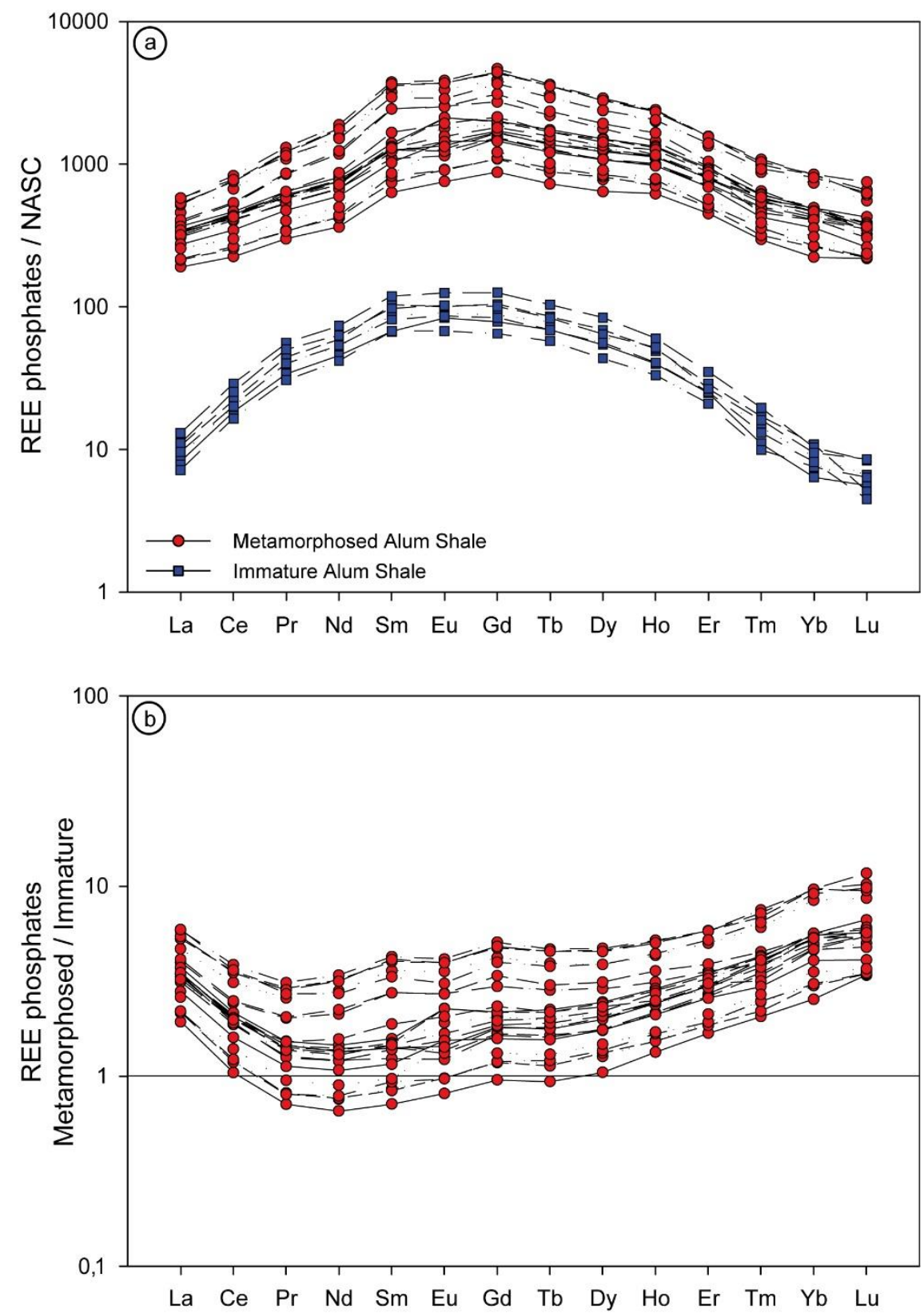

Fig. 15 REE patterns in apatite- $(\mathrm{CaF}[\mathrm{OH}])$ nodules from immature and metamorphic Alum Shale. All spectra are normalized to North American Shale Composite (NASC REE concentrations after Gromet et al., 1984) and metamorphic shales values are multiplied by 10 to improve readability 

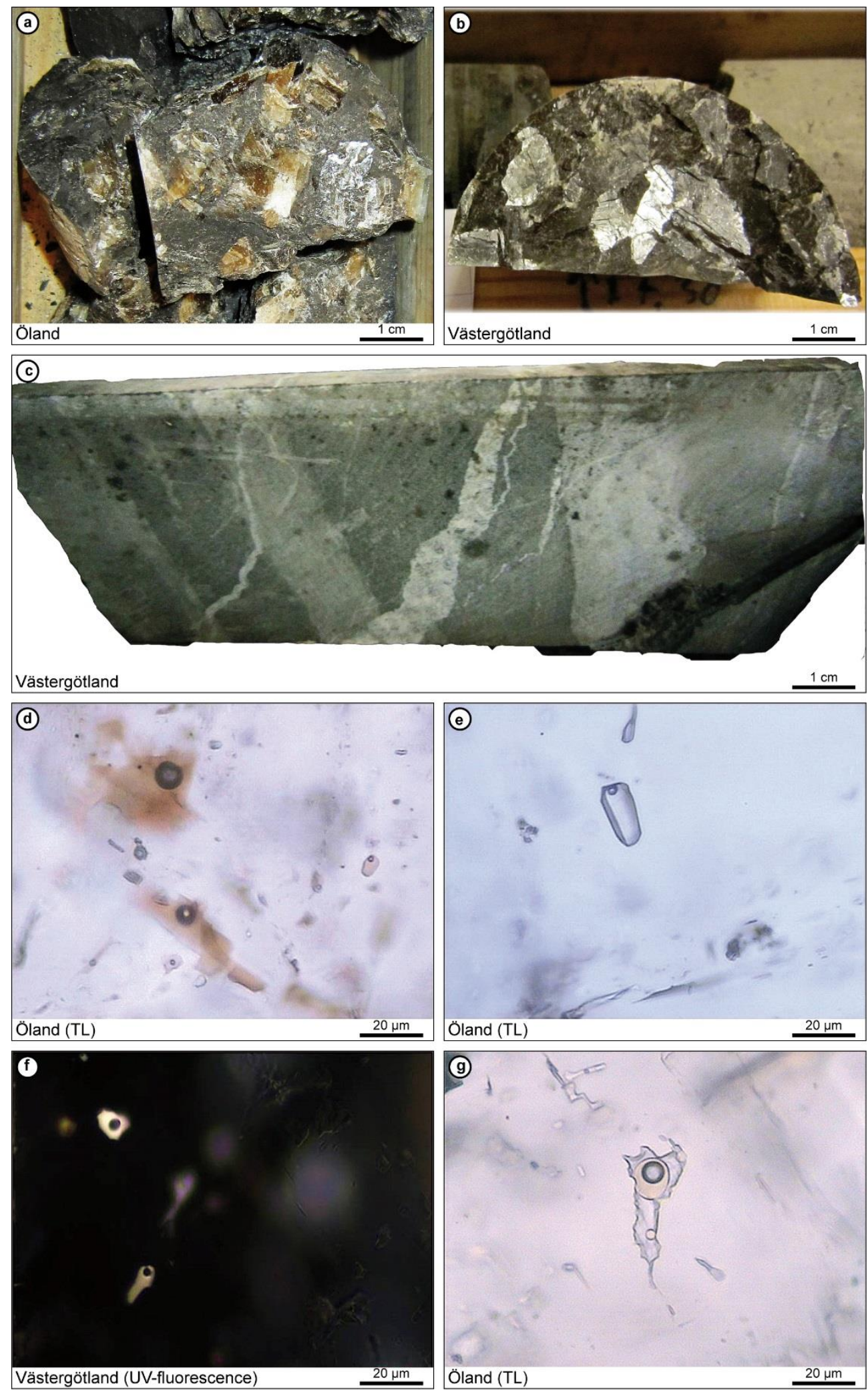

Fig. 16 a. Breccia with angular calcite crystals (Öland); b. Top view of calcite concretion (beef) with centimetric crystals (Västergötland); c. Hydrocarbonbearing inclusions in calcite (Öland); d. Aqueous inclusion in calcite (Öland); e. UV-fluorescent oil inclusions (Västergötland); f. 3-phase (oilwater-gas) inclusion (Öland) 

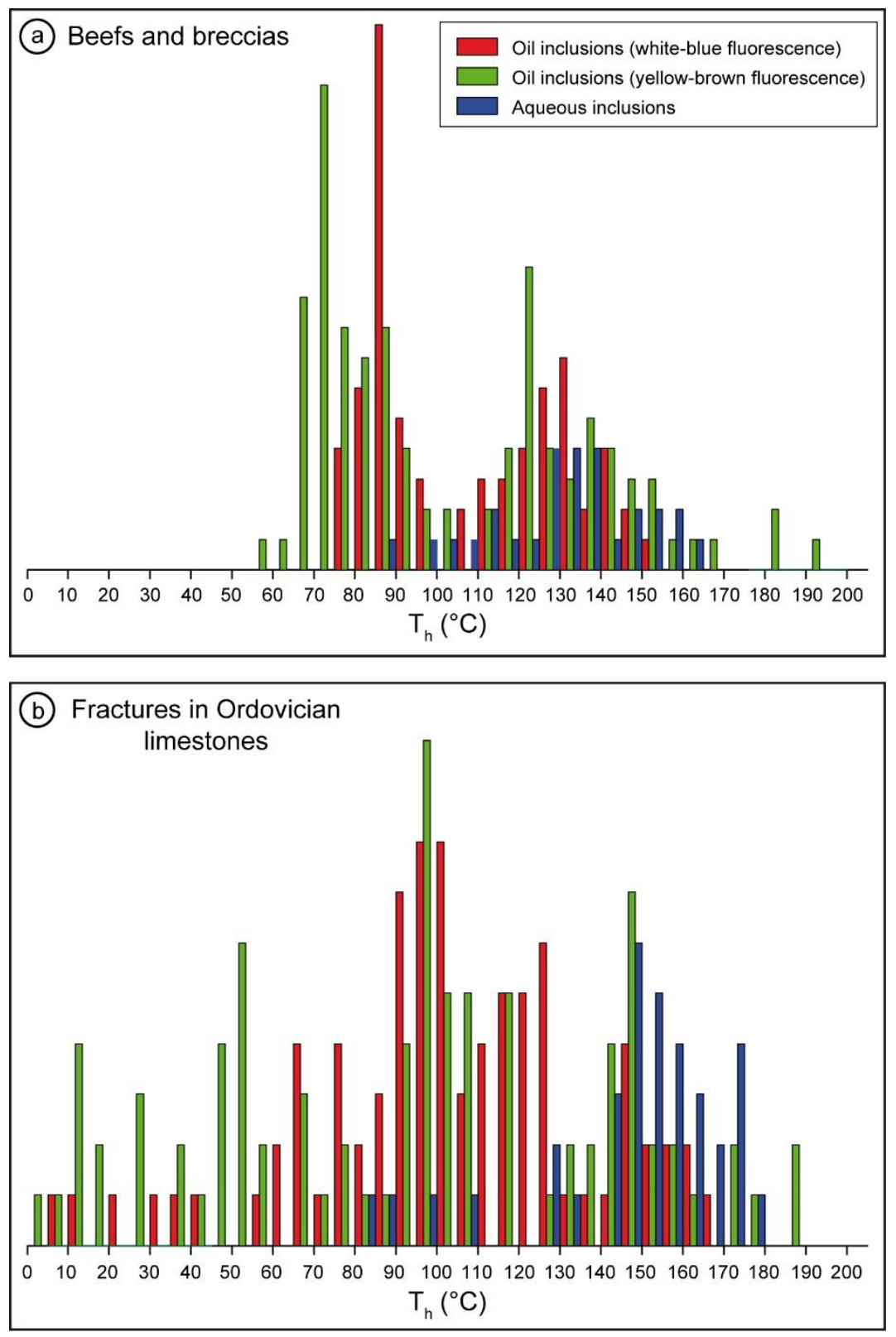

Fig. 17 Histograms of homogenization temperatures for fluid inclusions in concretions (a) and fracture fillings in Ordovician limestones (b) 


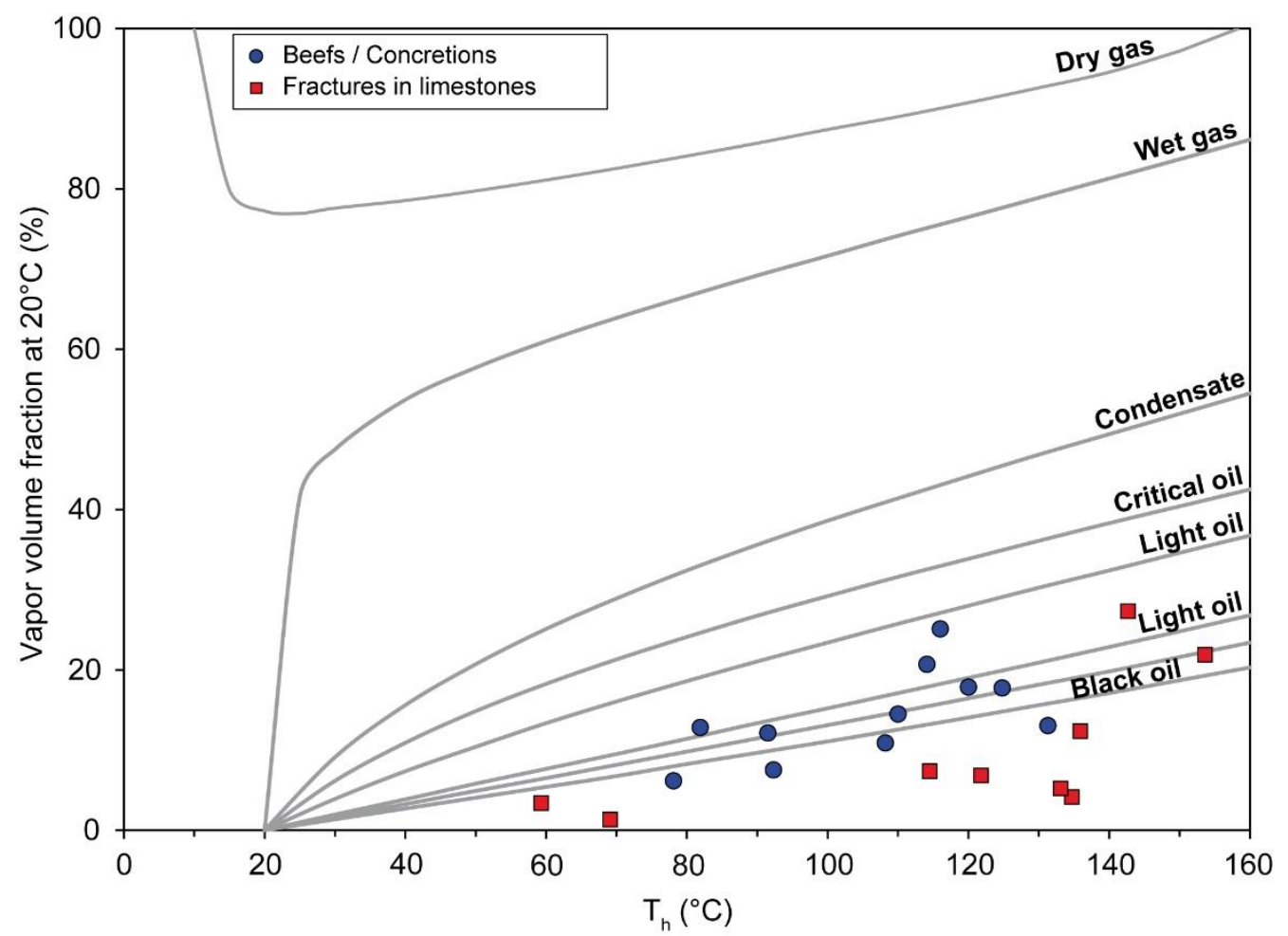

Fig. 18 Evolution of vapor volume fraction with homogenization temperature for various hydrocarbon-bearing inclusions in concretions (blue circles) and fractures (red squares) 

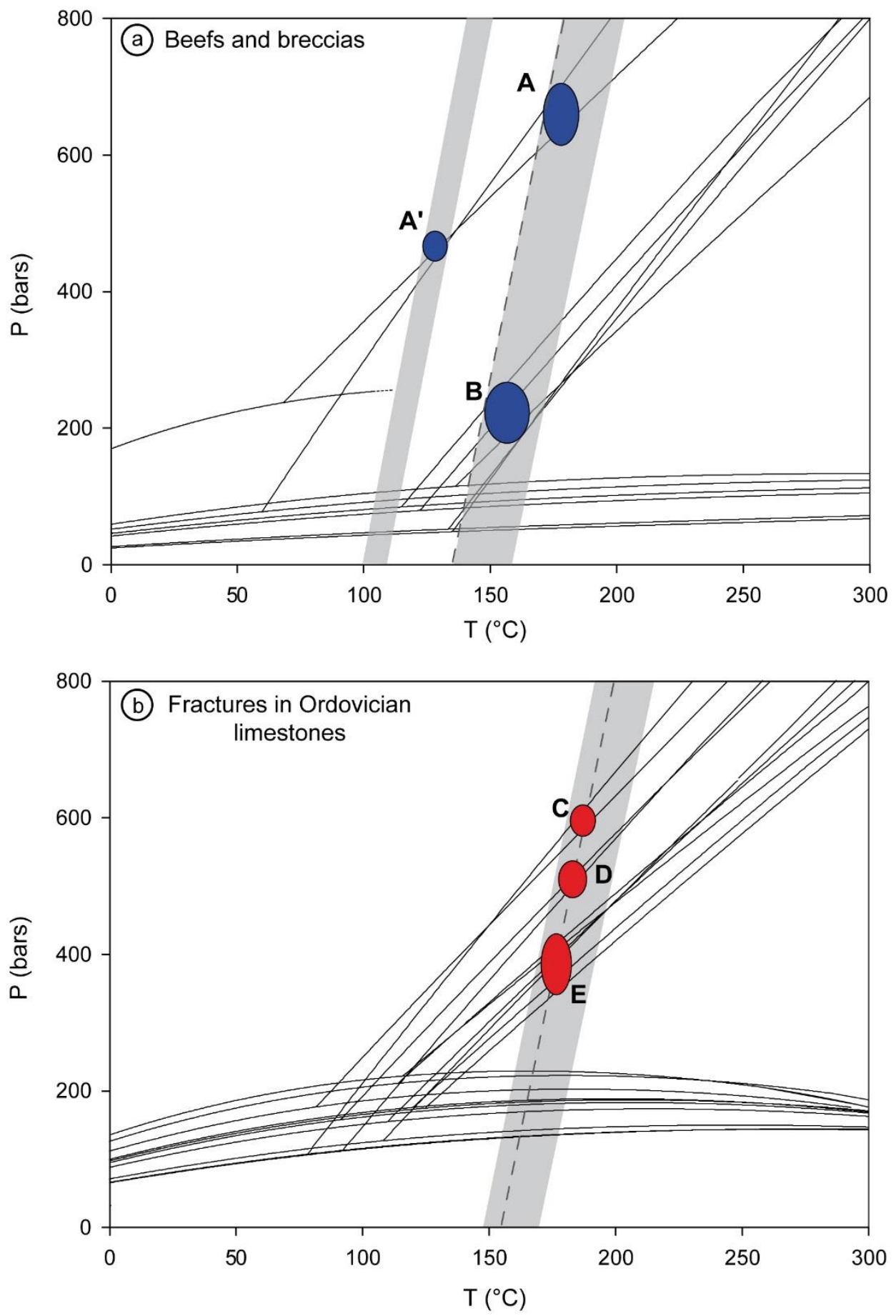

Fig. 19 Pressure-Temperature diagrams for inclusions in concretions (a) and fractures (b). Black lines represent isochores and isopleths of petroleum inclusions. Gray bands represent domain of isochores for aqueous inclusions. Dotted line is determined with the mode of homogenization temperatures and the mean salinity of aqueous inclusions. Trapping conditions correspond to intersection of intersection domains in blue for concretions $\left(A^{\prime}, A, B\right)$ and in red for fractures $(C, D$, and $E)$ 

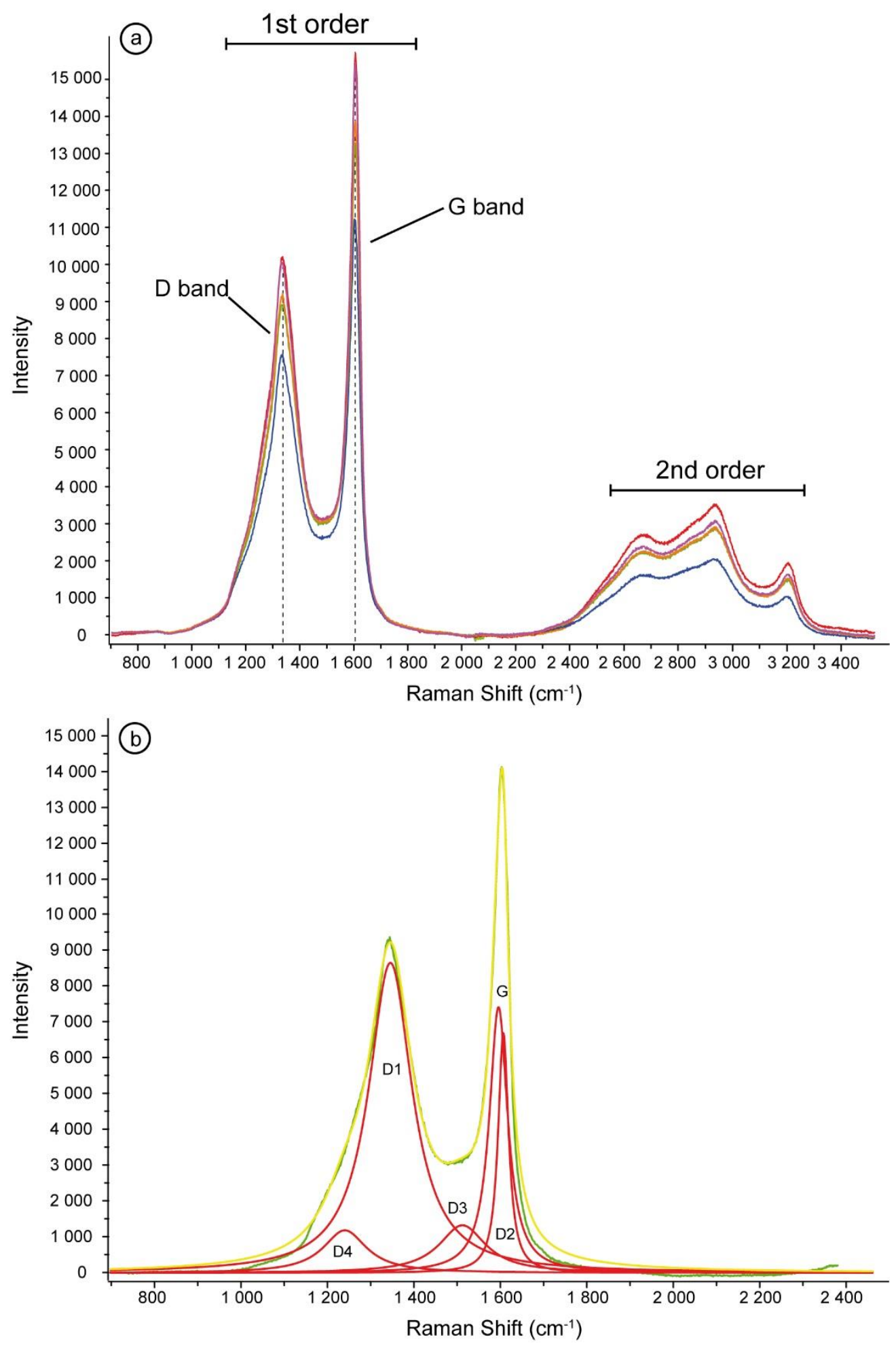

Fig. 20 a. Example of Raman spectra obtained on carbonaceous matter in Alum Shale; b. Peak fitting on first order region of Raman spectra using Lorentzian profiles. Complete dataset in table 3 

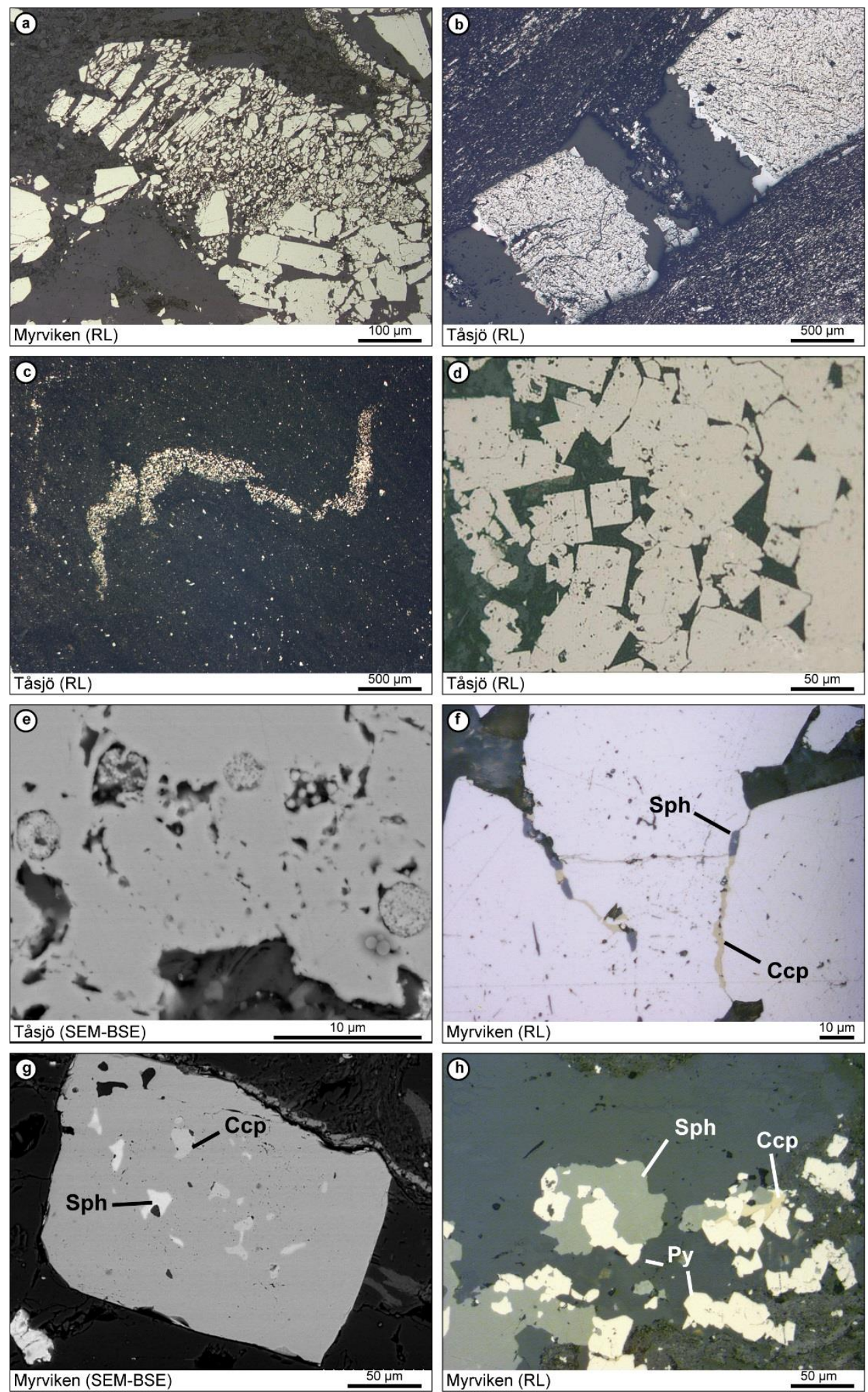

Fig. 21 Sulfide modifications in metamorphic Alum Shale. a. Cataclased massive pyrite (Myrviken); b. Fractured massive pyrite with pyrite overgrowths and late calcite fillings (Tåsjö); c. Folded bed of framboids and (sub)euhedral pyrites (Tåsjö); $d$. Interpenetrative boundaries on euhedral pyrites (Tåsjö); e. Framboids in synmetamorphic pyrite overgrowths (Myrviken); f. Fractures in pyrites filled with chalcopyrite and sphalerite (Myrviken); g. Massive pyrite with chalcopyrite and sphalerite inclusions (Myrviken); h. Pyrite-chalcopyrite-sphalerite paragenesis (Myrviken). Ccp: chalcopyrite, Pyr: pyrite, Sph: sphalerite 

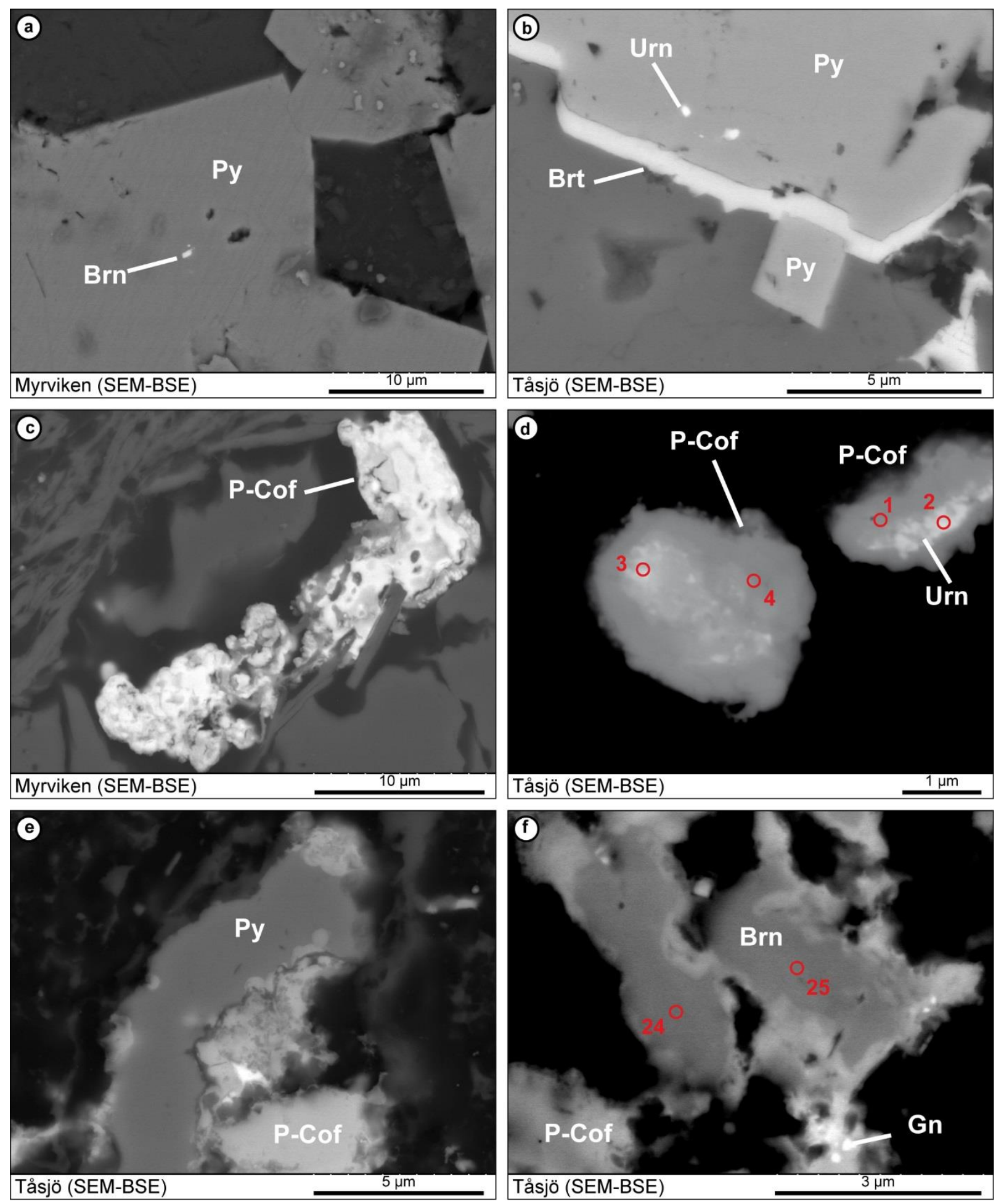

Fig. 22 a. Brannerite (white) in syn-metamorphic pyrites (Myrviken); b. Uraninite (white dots) in syn-metamorphic pyrites surrounded by barite (Tåsjö); c. Uranium phospho-silicates in metamorphic Alum Shale (Myrviken); d. Altered uraninite core (white) rimmed by uranium phospho-silicates (Tåsjö); e. Pyrite rimmed by U-Ti phospho-silicates (Tåsjö); f. Brannerite rimmed by U-Ti phospho-silicates (Tåsjö). Brn: brannerite, Brt: barite, Gn: galena, P-cof: uranium phospho-silicates of various composition (see text for details), Py: pyrite, Urn: uraninite. Red circles correspond to uranium mineral chemical analyses 

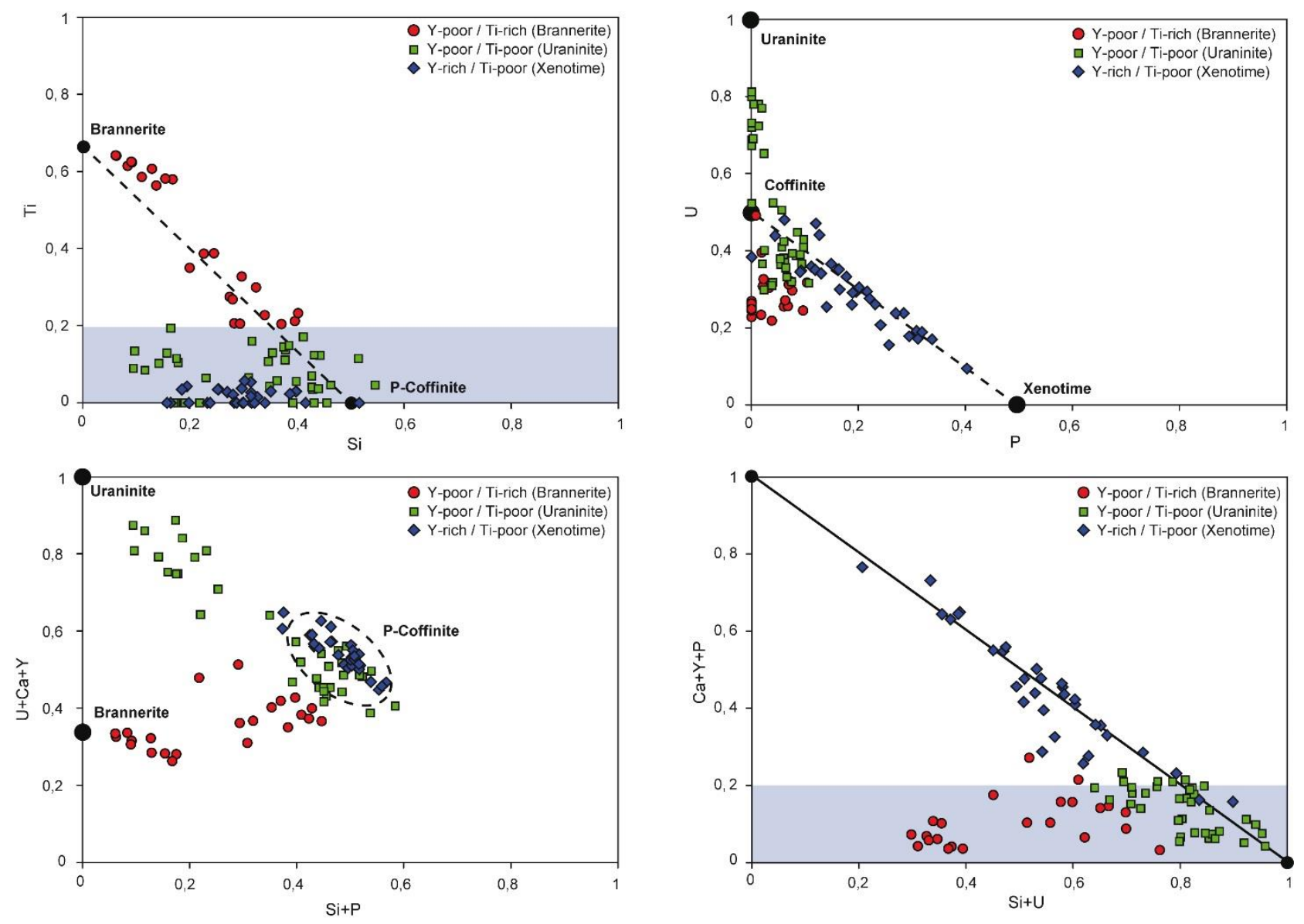

Fig. 23 Ti-Si (a), U-P (b), U+Ca+Y-Si+P (c) and $\mathrm{Ca}+\mathrm{Y}+\mathrm{P}-\mathrm{U}+\mathrm{Si}(\mathrm{d})$ diagrams for U-Ti-Y minerals in Alum Shale (APFU Atoms Per Formula Unit). Theorical uraninite, (P-)coffinite, brannerite and xenotime are indicated by large black dots. Circles represent Y-poor/Tirich minerals (Brannerite group), squares represent $\mathrm{Y}$-poor/Ti-poor minerals (Uraninite group) and diamonds represent $\mathrm{Y}$-rich/Ti-poor minerals (Xenotime group) 


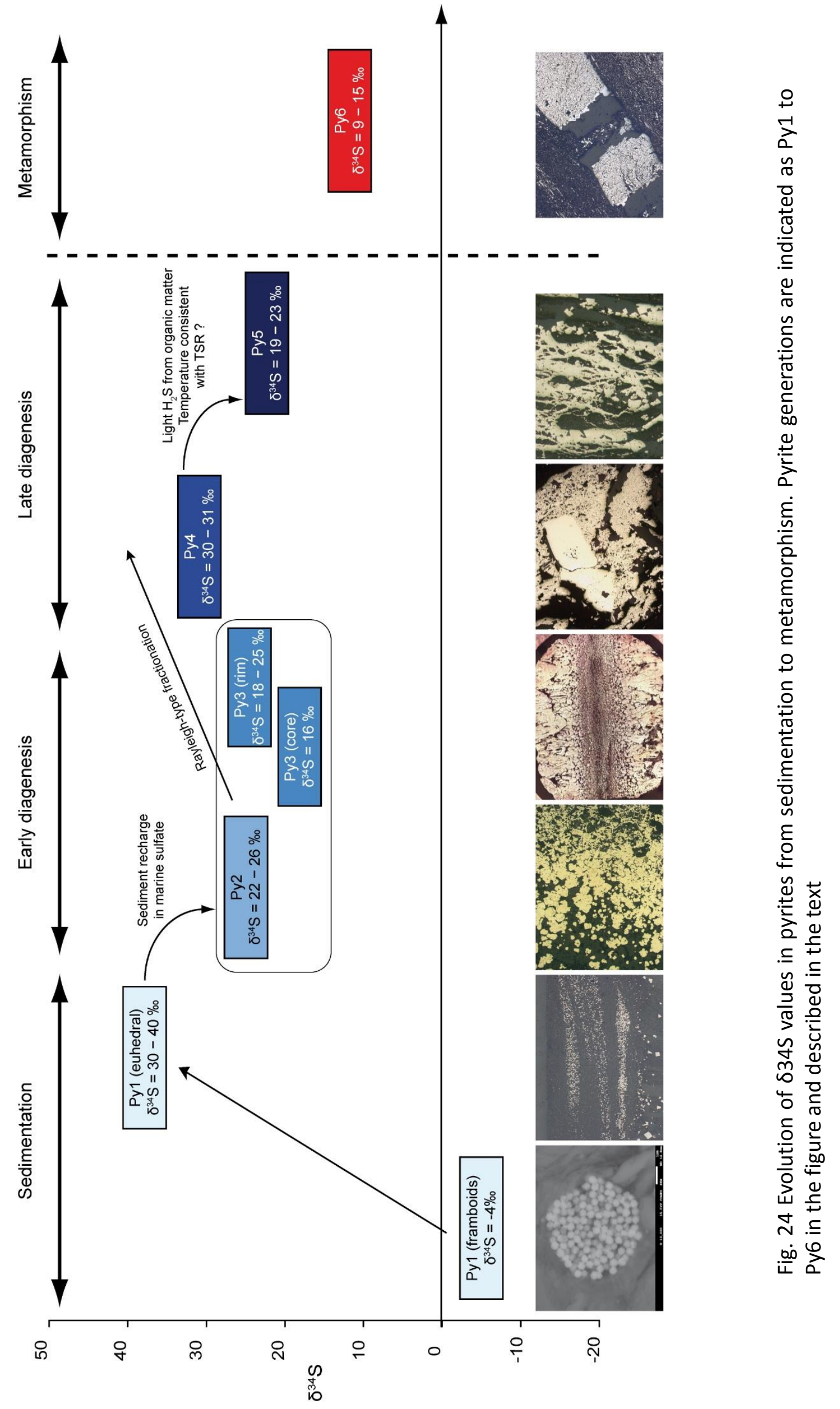




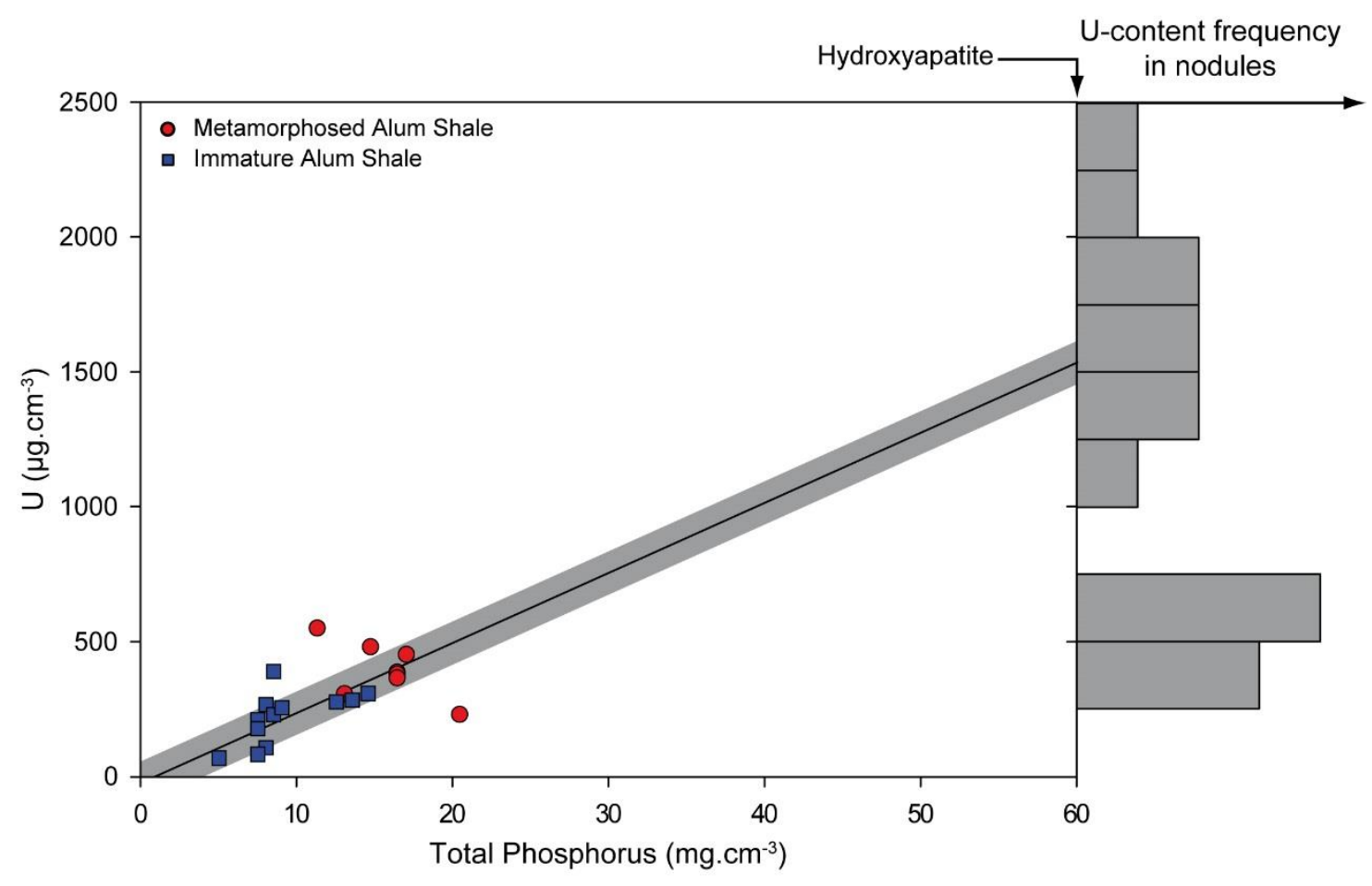

Fig. 25 Uranium-phosphorus plot for the Alum Shale Formation for whole rock (same data as Fig. 6b) and discrete uranium concentrations in phosphate nodules (frequency of occurrence histogram on the right). The shaded line illustrates the extrapolation at $60 \mathrm{mg} . \mathrm{cm}-3$ of phosphorus (average phosphorus content in apatite-(CaF $[\mathrm{OH}])$ 


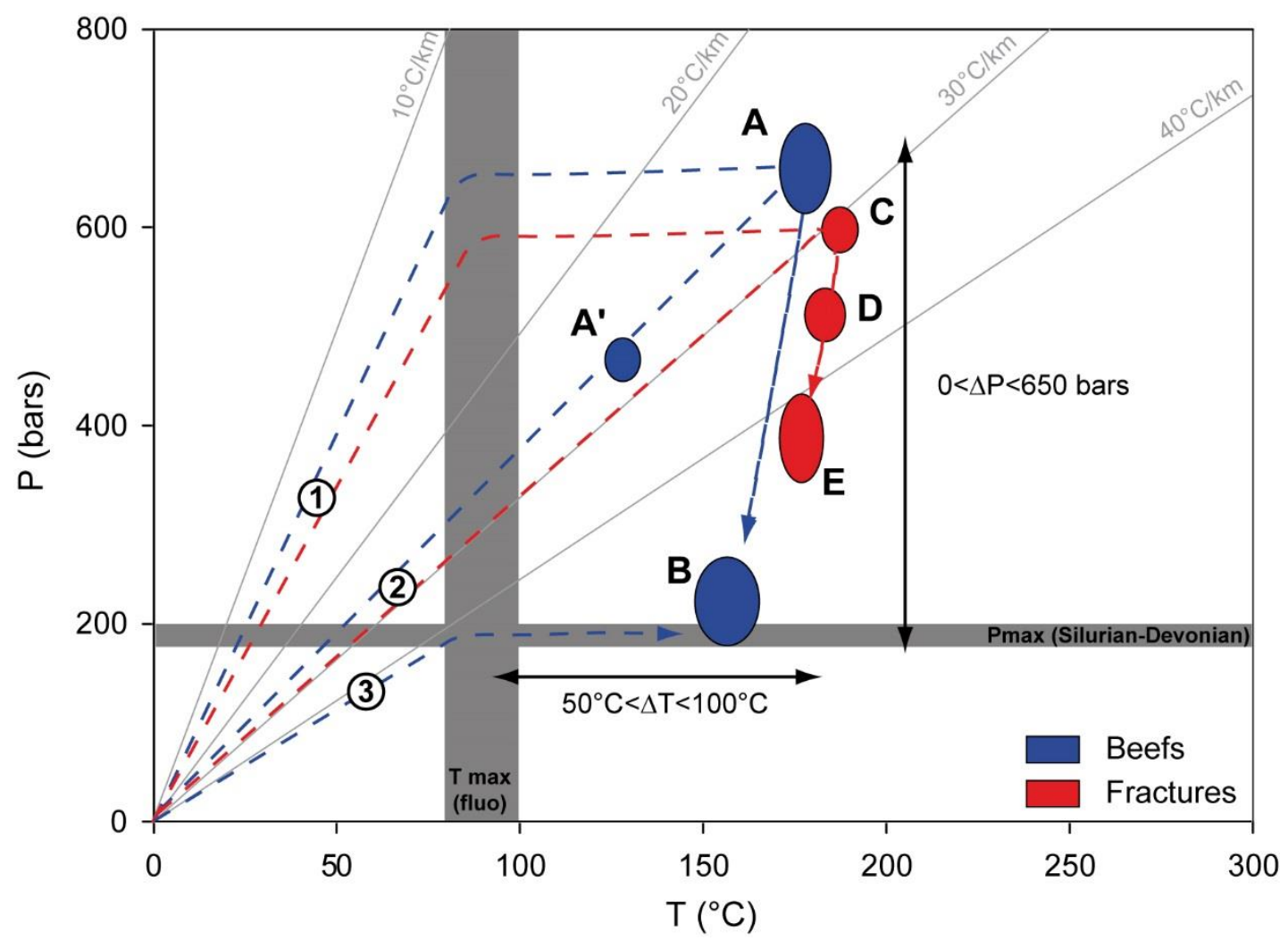

Fig. 26 Pressure-Temperature diagram with trapping condition of fluid inclusions and possible evolution pathways: 1) low geothermal gradient pathway $\left.\left(<20^{\circ} \mathrm{C} / \mathrm{km}\right) ; 2\right) 20-30^{\circ} \mathrm{C} / \mathrm{km}$ geothermal pathway; 3$)$ low burial 


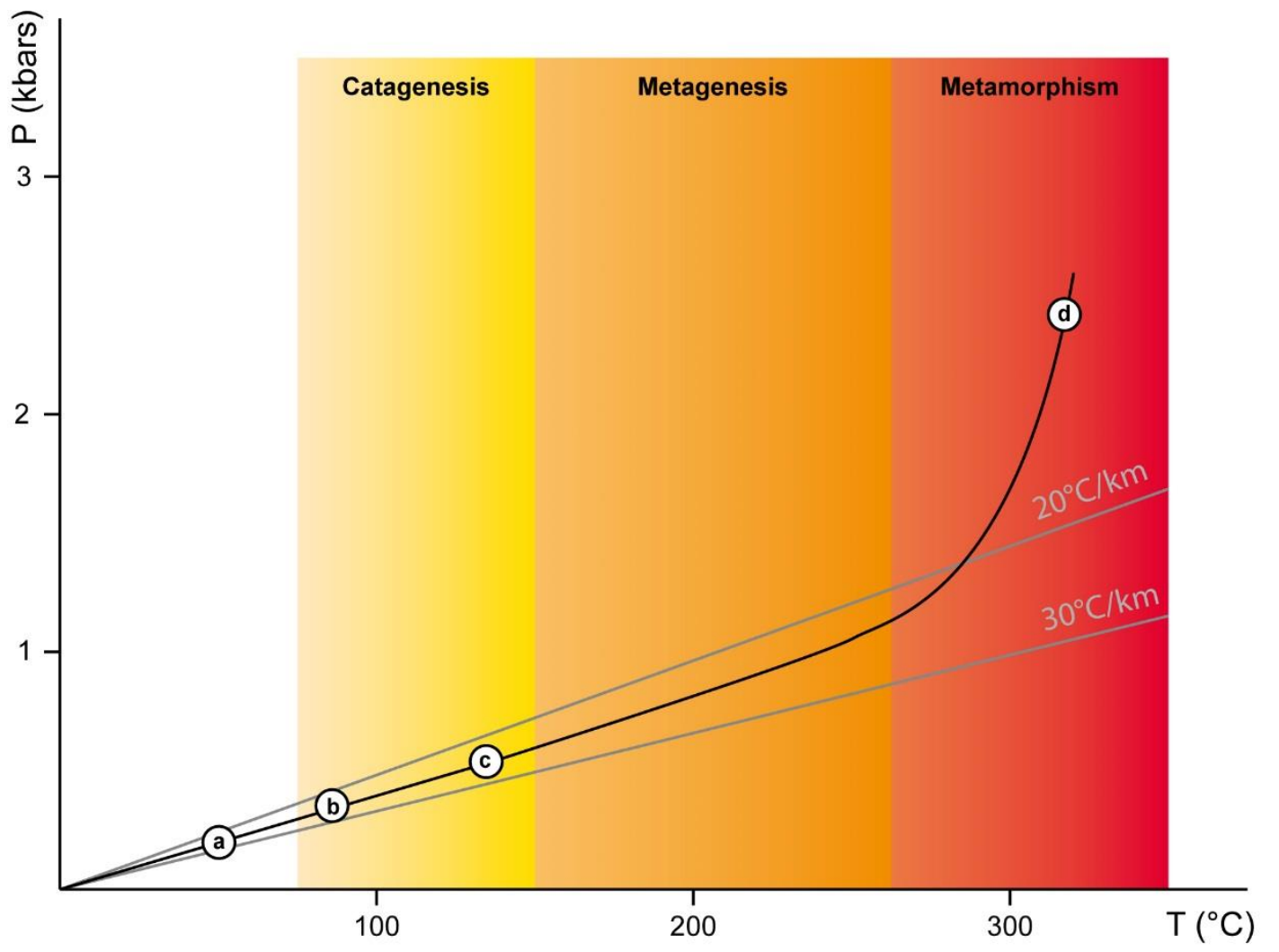

(a)
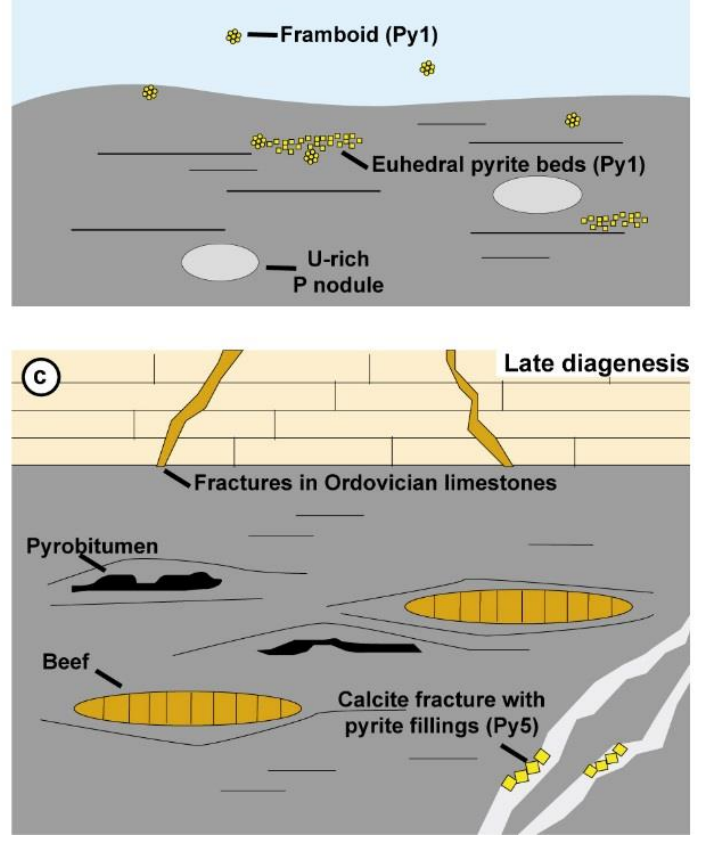

(b)
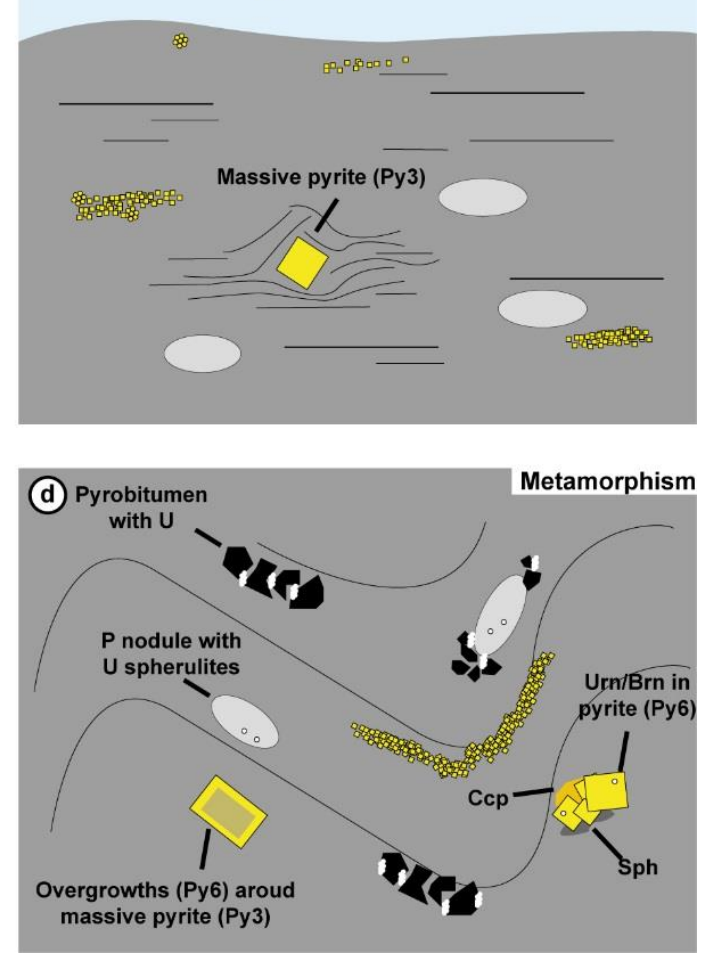

Fig. 27 Schematic scenario proposed to describe the evolution of organic matter, sulfides and uranium in the Alum Shale Formation, from sedimentation to Greenschist metamorphism 